ANDRÊSSA ABY FARAJ LINHARES MACIEL

DEFICIÊNCIA PARCIAL DA PROTEÍNA TRANSPORTADORA DE TIROXINA (TBG): ESTUDO DO GENE SERPINA7 E PADRÃO DE INATIVAÇÃO DO CROMOSSOMO $X$ EM UMA FAMÍLIA BRASILEIRA 


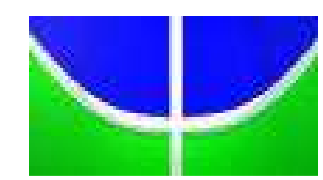

UNIVERSIDADE DE BRASÍLIA FACULDADE DE CIÊNCIAS DA SAÚDE PROGRAMA DE PÓS-GRADUAÇÃO EM CIÊNCIAS DA SAÚDE

DEFICIÊNCIA PARCIAL DA PROTEÍNA TRANSPORTADORA DE TIROXINA (TBG): ESTUDO DO GENE SERPINA7 E PADRÃO DE INATIVAÇÃO DO CROMOSSOMO $X$ EM UMA FAMÍLIA BRASILEIRA

Tese apresentada como requisito
parcial para obtenção do Título de
Doutor em Ciências da Saúde
pelo Programa de Pós-graduação
em Ciências da Saúde da
Universidade de Brasília.

Orientadora: Prof ${ }^{\mathrm{a}}$. Dra. Adriana Lofrano Alves Porto Universidade de Brasília UnB

Brasília-DF

2016 


\title{
DEFICIÊNCIA PARCIAL DA PROTEÍNA TRANSPORTADORA DE TIROXINA (TBG): ESTUDO DO GENE SERPINA7 E PADRÃO DE INATIVAÇÃO DO CROMOSSOMO $X$ EM UMA FAMÍLIA BRASILEIRA
}

\author{
Tese apresentada como requisito \\ parcial para obtenção do Título de \\ Doutor em Ciências da Saúde \\ pelo Programa de Pós-graduação \\ em Ciências da Saúde da \\ Universidade de Brasília
}

Aprovado em

BANCA EXAMINADORA

$\overline{\text { Prof }^{a} \text {. Dra. Adriana Lofrano Alves Porto (Orientadora) }}$ Universidade de Brasília

Prof ${ }^{a}$ Dra Juliana Forte Mazzeu de Araújo Universidade de Brasília

Prof. Dr. Augusto César Florêncio Costa Universidade de Brasília

Prof. Dr. Luiz Cláudio Gonçalves de Castro Universidade de Brasília

Prof $^{\mathrm{a}}$ Dra. Valdenize Tiziani Hospital da Criança de Brasília

Prof $^{\mathrm{a}}$. Dra. Carine Royer (Suplente) Universidade de Brasília 
A minha filha Luiza, meu bem mais precioso, Dedico esta Tese 


\section{AGRADECIMENTOS}

À Deus, primeiramente, sempre. Sem fé nada é possível.

A minha filha, Luiza, nasceu no meio dessa caminhada, e deu todo sentido à minha vida e foi por ela que tive forças para finalizar essa jornada.

Ao meu esposo, Leonnardo Cirilo Sampaio Maciel, pelas inúmeras compreensões durante essa trajetória e por seu amor.

A minha família, meu pai e minha mãe, e principalmente a minhas irmãs pelas inúmeras ajudas e pelo incentivo sempre.

A minha orientadora Dra. Adriana Lofrano Alves Porto, por toda paciência e por sempre acreditar que seria possível mesmo diante de todos os obstáculos para a conclusão desse trabalho. Agradeço todo o conhecimento adquirido nesses anos e por seus aconselhamentos de vida.

A professora Prof ${ }^{\underline{a}}$ Dra. Juliana Forte Mazzeu de Araújo, juntamente a com a equipe de Genética da Biologia da UnB, Diana, Rafaela, Brisa e Fabíola, pelos ensinamentos da técnica da inativação do cromossomo X.

Ao Professor Dr. Lucas Bleicher da UFMG, que realizou a análise da estrutura e modelagem da TBG e do mutante.

A Sarah e Cristiane, amigas que o doutorado me proporcionou a conhecer e que levarei para o resto da minha vida. Em especial, a Cris, que cedeu suas pacientes e ideias preciosas para essa pesquisa.

Ao Matheus, que sempre ajudou e iniciou esse trabalho, meu sincero agradecimento.

As minhas eternas amigas, Fernanda, foi quem abriu as portas para UnB apresentando-me a Profa. Adriana, Sandra e Carol por estarem sempre presentes em todas as etapas da minha vida.

Aos colegas e funcionários do Grupo de Pesquisa do Laboratório de Farmacologia Molecular da UnB e aos professores, principalmente Profa Angélica Amorin Amato, por todas as experiências vividas.

Aos órgãos financiadores que disponibilizaram a realização dessa pesquisa e a UnB pela infraestrutura oferecida e concessão de bolsa Reuni.

Ao Programa de Pós-Graduação em Ciências da Saúde por todos pedidos aceito para a conclusão desse trabalho. 


\section{REFLETINDO SOBRE O ATO DE APRENDER}

"Aprender não é acumular certezas

Nem estar fechado em respostas

Aprender é incorporar a dúvida

E estar aberto a múltiplos encontros

Aprender não é dar por consumada uma busca

Aprender não é ter aprendido

Aprender não é nunca um verbo do passado

Aprender não é um ato findo

Aprender é um exercício constante de renovação

Aprender é sentir-se humildemente sabedor de seus limites, mas com a coragem de não recuar diante dos desafios

Aprender é debruçar-se com curiosidade sobre a realidade

É reinventá-la com soltura dentro de si

Aprender é conceder lugar a tudo e a todos

E recriar o próprio espaço

Aprender é reconhecer em si e nos outros o direito de ser dentro de inevitáveis repetições porque aprender é caminhar com seus pés um caminho já traçado

É descobrir de repente uma pequena flor inesperada

É aprender também novos rumos onde parecia morrer a esperança Aprender é construir e reconstruir pacientemente

Uma obra que não será definitiva porque o humano é transitório Aprender não é conquistar nem apoderar-se, mas peregrinar Aprender é estar sempre caminhando, não é reter, mas comungar. Tem que ser um ato de amor para não ser um ato vazio." 


\section{RESUMO}

Introdução: A globulina carreadora de tiroxina (TBG) é a principal proteína transportadora dos hormônios tireoidianos em humanos. Anormalidades hereditárias que comprometem a estrutura e função da proteína resultam em deficiência completa (TBG-CD) e parcial de TBG (TBG-PD). O gene que codifica a TBG é o SERPINA7 e está localizado no braço longo do cromossomo X (Xq22.2). Objetivos: Os objetivos desse estudo foram realizar análise molecular do gene SERPINA7 em uma família brasileira com TBG-PD, investigar o padrão de inativação da região do cromossomo $X$ que compreende o gene, bem como realizar modelagem estrutural da proteína mutante e análise estrutural comparativa à família de proteínas serpinas, a fim de inferir efeitos funcionais da mutação identificada. Métodos: O DNA genômico foi extraído do caso índice, do seu pai, da sua irmã gêmea dizigótica e seus dois irmãos. Reação de polimerização em cadeia (PCR) foi utilizada para amplificação do gene SERPINA7 e os produtos foram submetidos a sequenciamento pelo método Sanger. $\mathrm{O}$ padrão de inativação do cromossomo $X$ foi avaliado no caso índice por meio da análise do padrão de metilação do gene que codifica o receptor androgênico $(A R$ gene), que está localizado próximo do gene SERPINA7 (Xq11.2). Análises estruturais na família das serpinas foram feitas usando PFSTATS, que também foi usado para mapear posições equivalentes em todos homólogos humanos. A modelagem molecular foi realizada usando protocolo descrito por Feyfant e colaboradores. Resultados: Uma nova mutação missense no gene SERPINA7 (p.R35W) foi encontrada em heterozigose no caso índice e em hemizigose nos seus irmãos do sexo masculino. Eles apresentaram baixos níveis séricos de TBG compatíveis com TBGPD. Esta mutação consistiu na substituição de um nucleotídeo $(C>T)$ na posição 163 do éxon 1, que resultou na troca de uma arginina por um triptofano no códon 35 (p.R35W). O caso índice expressou uma razão de inativação do cromossomo $X$ de 20:80. Na mutação, o carbono alfa do resíduo 35 encontrata-se a cerca de $17 \AA$ de distância do átomo mais próximo do $T_{4}$, e este resíduo reside numa hélice, com a sua cadeia lateral de frente para o solvente. A Arg35 está também envolvida com interações eletrostáticas com os principais oxigênios das cadeias da Met264 e Asp261, e também do oxigênio do grupo carboxamida na Asn32 e ainda com duas moléculas de água. Os padrões de conservação e de correlação envolvendo este resíduo, pode ser visto que os resíduos mais frequentes nestas posições são as lisinas $(26,7 \%)$, argininas $(18,4 \%)$ e glutaminas $(10,8 \%)$. Triptofanos, como na proteína mutante, são extremamente raros $(0,1 \%)$ e não há significantes $\left(p<10^{-10}\right)$ correlações de emparelhamentos envolvendo resíduos nesta posição. Conclusão: $O$ presente estudo relatou uma nova variante do gene SERPINA7 associada à TBG-PD em três irmãos: uma mulher e dois homens. O padrão de inativação do cromossomo $X$ observado no caso índice aponta para um desvio do padrão de inativação, o que corrobora a variabilidade genótipo-fenótipo em mulheres com mutações heterozigóticas no gene SERPINA7, uma condição rara. A natureza hidrofóbica do triptofano poderia resultar em um fragmento apolar que estaria significativamente exposto ao solvente na proteína mutante podendo resultar em agregação da proteína e/ou enovelamento incorreto, e consequente defeito no transporte sérico de T4. Adicionalmente, esses achados sugerem que a TBG e seus homólogos dentro da família das serpinas poderiam ser igualmente afetados por mutações nesta posição rompendo a rede de interações com seus vizinhos na estrutura nativa, com provável impacto funcional.

Palavras-chave: TBG, deficiência parcial, gene SERPINA7, hormônios tireoidianos, inativação do cromossomo $X$. 


\section{ABSTRACT}

Background: Thyroxine-binding globulin (TBG) is the major human thyroid hormone transport protein. Inherited TBG abnormalities that implicated the protein's structure and function result in complete (TBG-CD) and partial (TBGPD) and TBG deficiency. The SERPINA7 gene encodes TBG and it is located on the long arm of the $X$ chromosome (Xq22.2). Objectives: The purpose of this study was to perform the molecular analysis of the SERPINA7 gene in a Brazilian family with TBG-PD, investigate the X-chromosome inactivation pattern region comprising the gene as well as perform structural modeling of the mutant protein and comparative structural analysis of the serpin family of proteins, in order to infer functional effects of these mutations. Methods: Genomic DNA was extracted from the female proband, her father, her dizygotic twin sister and her two brothers. The samples were subjected to polymerase chain reaction (PCR) for SERPINA7 gene amplification and the products were sequenced by the Sanger method. The proband's sample was evaluated by methylation analysis using the human androgen receptor $(A R)$ gene, which is located next to the TBG gene (Xq11.2). Structural analysis of the serpin family was analyzed using PFSTATS and was also used to map equivalent positions in all human homologs. The molecular modeling was using the protocol described by Feyfant et al. Results: A novel missense mutation in the SERPINA7 gene (p.R35W) was found in heterozygosity in the proband and in hemizygosity in her brothers. They presented low serum TBG levels compatible with TBG-PD. This mutation consisted in a single nucleotide substitution (C>T) at position 163 of exon 1 which resulted in the replacement of an arginine by a tryptophan at codon 35 . The proband expressed an Xchromosome inactivation ratio of 20:80. In this mutation, the alpha carbon of residue 35 is about $17 \AA$ away from the closest atom from T4 and this residue lies in a helix, with its side chain facing the solvent. Arg35 is also involved in electrostatic interactions with the main chain oxygens of Met264 and Asp261, and also the oxygen on the carboxamide group in Asn32, besides interacting with two waters molecules. The conservation and correlation patterns involving this residue, it can be seen that the most frequent residues in these positions are lysines (26.7\%), arginines (18.4\%) and glutamines (10.8\%). Tryptophans are extremely rare $(0.1 \%)$, and there is no significant $\left(p<10^{-10}\right)$ pairwise correlations involving residues in this position. Conclusion: This study reported a new variant of the SERPINA7 gene associated with TBG-PD in three siblings: one woman and two men. The X-chromosome inactivation pattern verified in the proband corroborated that deviations in the inactivation pattern account for genotype-phenotype variability in women with heterozygous mutations in the SERPINA7 gene, a rare condition. The hydrophobic nature of tryptophan would result in an apolar patch that would be significantly exposed to the solvent can result in protein aggregation and/or misfolding, and the consequent defect in the serum $T_{4}$ transport. Additionally, these findings suggest that the TBG and its homologs in the serpin family could be similarly affected by mutations in this position which would disrupt the interaction network to its neighbors in the native structure, with probable functional impact.

Key words: TBG, partial deficiency, SERPINA7 gene, X-chromosome inactivation, thyroid hormone. 


\section{LISTA DE FIGURAS}

Figura 1. Corte histológico da tireoide .18

Figura 2. Aspectos anatômicos da glândula tireoide, mostrando principalmente os lobos direito e esquerdo da tireoide.

Figura 3. Fórmulas químicas estruturais dos hormônios tireoideanos e dos compostos relacionados 21

Figura 4. Representação esquemática do funcionamento do eixo hipotalâmicohipofisário-tireoidano. 23

Figura 5. Ilustração do Mecanismo de ação do Hormônio Tireoideano .29

Figura 6. Figura esquemática da K1-antitripsina nativa 32

Figura 7. Estrutura molecular da TBG: Loops reativos (em amarelo). 34

Figura 8. Sequência de aminoácido traduzida do gene SERPINA7. 35

Figura 9. Organização genômica e localização cromossomal da principal proteína de ligação ao hormônio tireoideano no sangue. 36

Figura 10. Representação da localização do gene que codifica 0 receptor androgênico $(A R)$ no cromossomo $X$ 58

Figura 11. Diagrama da região amplificada no primeiro éxon do gene do receptor de andrógeno humano $(A R)$. 61 
Figura 12. A. Heredograma da família estudada e resultados dos exames laboratoriais da função tireoideana de três irmãos afetados pela deficiência parcial de TBG (TBG-PD) devido à mutação p.R35W no gene SERPINA7. 66

Figura 13. Eletroferogramas do sequenciamento de parte do éxon 1 do gene SERPINA7, mostrando a substituição de uma citosina (C) por uma timina (T) na posição correspondente ao códon 35 da proteína madura (mutação p.R35W) 68

Figura 14. Análise do padrão de inativação do cromossomo $X$ da mulher com a deficiência parcial de TBG (caso índice) 69

Figura 15. Estrutura da TBG mostrando a localização do mutante R35W e suas interações. 70

Figura 16. Representação esquemática da proteína TBG com a numeração dos aminoácidos do peptídeo sinal (retângulo cinza; aminoácidos -20 a -1) e da proteína madura (retângulos brancos; aminoácidos 1 a 395), bem como respectivos números dos éxons codantes da proteína madura (retângulos brancos numerados de 1 a 4 .79

Figura 17. Propriedades de algumas variantes da TBG que causam deficiência parcial de TBG, como padrão migração em electroforese IEF (focalização isoelétrica), estabilidade e afinidade para ligação ao $T_{4}$ .80 


\section{LISTA DE TABELAS}

Tabela 1: Principais características das iodotironinas desiodases.

Tabela 2. Propriedades e parâmetros metabólicos das principais proteínas de transportadoras de hormônios tireoideanos séricos. .25

Tabela 3. Função, grupo e localização das Serpinas humanas classificadas em inibidoras e não inibidoras. 31

Tabela 4. Oligonucleotídeos iniciadores utilizados para amplificação dos éxons 1 a 4 do gene SERPINA7. .55

Tabela 5. Quantitativo de reagentes para realização da PCR para os éxons 1 ao 4 do gene SERPINA7. .56

Tabela 6. Descrição das condições para realização da PCR para nos éxons 1 ao 4 do gene SERPINA7. .56

Tabela 7. Oligonucleotídeos iniciadores utilizados para amplificação do éxon 1 do gene $A R$.

Tabela 8. Descrição das condições para realização da PCR para éxon 1 do gene $A R$ .60

Tabela 9 - Resultados dos exames laboratoriais do caso índice em uso de $50 \mu \mathrm{g} / \mathrm{dia}$ de levotiroxina e após sua retirada. .65

Tabela 10 - Mutações no gene SERPINA7 já descritas, incluindo a do presente estudo, e que resultam em deficiência completa ou parcial de TBG $.76 / 77$ 


\section{LISTA DE ABREVIATURAS/SIGLAS}

\begin{tabular}{ll}
$\%$ & Percentual \\
$\AA$ & Ångström \\
${ }^{0} \mathrm{C}$ & Grau celsius \\
$\mathrm{Cm}^{3}$ & Centímetro cúbico \\
$\mathrm{mL}$ & Mililitros \\
$\mathrm{mg} / \mathrm{mL}$ & Miligrama/mililitro \\
$\mu \mathrm{gg}$ & Micrograma (mcg) \\
$\mu \mathrm{g} / \mathrm{mL}$ & Micrograma/mililitro \\
$\mu \mathrm{g} / \mathrm{dL}$ & Micrograma/decilitro \\
$\mu \mathrm{L}$ & Microlitro \\
$\mu \mathrm{M}$ & Micromolar \\
$\mu \mathrm{m}$ & Micrômetro \\
$\mu \mathrm{mol} / \mathrm{L}$ & Micromol/litro \\
$\mathrm{ng} / \mathrm{dL}$ & Nanograma/decilitro \\
$\mathrm{nM}$ & Nanomolar \\
$\mathrm{nmol} / \mathrm{L}$ & Nanomolar/litro \\
$\mathrm{kDa}$ & Kilodalton \\
$\mathrm{kbps}$ & Kilobits \\
aa & Aminoácidos \\
Anti-Tg & Anti-tireoglobulina \\
Anti-TPO & Anti-tireoperoxidase \\
AR & Gene do receptor de andrógenos \\
$\mathrm{ATIII}$ & Órfãos antitrombina \\
$\mathrm{BSA}$ & Estabilizante de proteínas derivado do inglês Bovine \\
$\mathrm{CIX}$ & Serum Albumin \\
$\mathrm{CSF}$ & Centro de inativação do cromossomo X \\
$\mathrm{D} 1$ & Fluido cérebro-espinhal \\
$\mathrm{D} 2$ & Desiodase tipo 1 \\
$\mathrm{D} 3$ & Desiodase tipo 2 \\
$\mathrm{DBD}$ & Desiodase tipo 3 \\
$\mathrm{DIT}$ & Domínio de ligação ao DNA \\
\hline
\end{tabular}




\begin{tabular}{|c|c|}
\hline DNA & Ácido desoxirribonucléico \\
\hline dNTP & Desoxirribonucleotídeos fosfatados \\
\hline EDTA & Ácido etileno diaminotetracético \\
\hline IEF & Focalização isoelétrica \\
\hline HCFII & Co-fator II da heparina \\
\hline Hepes & $\begin{array}{l}\text { N-(2-hidroxietil) piperazina-N'-(2-ácido etanosulfônico), } \\
\text { tampão orgânico }\end{array}$ \\
\hline HNF & 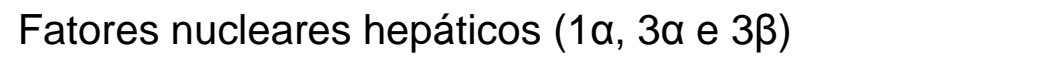 \\
\hline HSA & Albumina de soro humano \\
\hline HTs & Hormônios tireoideanos \\
\hline $\mathrm{KCl}$ & Cloreto de Potássio \\
\hline LDB & Domínio de ligação ao ligante \\
\hline MIT & Monoiodotirosina \\
\hline $\mathrm{MgCl}_{2}$ & Cloreto de magnésio \\
\hline MTB & Maquinaria de transcrição basal \\
\hline N-Cor & Co-repressor nuclear \\
\hline $\mathrm{NH} 4 \mathrm{Cl}$ & Cloreto de Amônio \\
\hline $\mathrm{NH} 4 \mathrm{HCO} 3$ & Bicarbonato de Amônio \\
\hline$(\mathrm{NH} 4) 2 \mathrm{SO}_{4}$ & Sulfato de amônio \\
\hline NIS & Transportador transmembrana específico \\
\hline PCR & Reação em Cadeia da Polimerase \\
\hline PPAR & Receptor dos proliferadores peroxissomais \\
\hline RAR & Receptor do ácido retinoico \\
\hline RIA & Radioimunoensaio \\
\hline $\mathrm{RSL} / \mathrm{RCL}$ & $\begin{array}{l}\text { Centro reativo do loop, do inglês reactive site loop ou } \\
\text { reactive center loop (RCL) }\end{array}$ \\
\hline RNA & Ácido ribonucléico \\
\hline RNAm & RNA mensageiro \\
\hline RPB & Proteína ligadora do retinol \\
\hline rpm & Rotações por minuto \\
\hline $\mathrm{rT}_{3}$ & 3, 3', 5' triiodotironina ou $\mathrm{T}_{3}$ reverso \\
\hline $\mathrm{RXR}$ & Receptor do retinoide $X$ \\
\hline SDS & Dodecil sulfato de sódio \\
\hline SERPINA7 & Gene que codifica a TBG \\
\hline SMRT & Mediador da silenciação dos receptores dos hormônios \\
\hline
\end{tabular}


SRC-1

$\mathrm{T}_{2}$

$\mathrm{T}_{3}$

$\mathrm{T}_{4}$

$\mathrm{T}_{4}$ livre

$\mathrm{Tg}$

TBG

TBG-CD

TBG-E

TBG-PD

TBPA

TRAP/DRIP-1

TREs

$\mathrm{TRH}$

TRIS

TSH

$\mathrm{TT}_{3}$

$\mathrm{TT}_{4}$

TTR

VDR

XIST retinoideanos e tireoideanos

Co-ativador 1 do receptor de esteroide

Diiodotironina

3, 5, 3'-tri-iodo-L--tironina ou Triiodotironina

3, 5, 3', 5'-tetra-iodo-L-tironina ou Tiroxina

Tiroxina livre

Tireoglobulina

Proteína transportadora de tiroxina

Deficiência completa de TBG

Excesso de TBG

Deficiência parcial de TBG

Pré-albumina ligada a tiroxina

Mediador silencioso para TR e RAR

Elementos responsivos ao hormônio tireoideano

Hormônio liberador de tireotrofina

2-Amino-2-hidroximetil-propano-1,3-diol

Hormônio tireotrófico ou estimulador da tireoide

$\mathrm{T}_{3}$ total

$\mathrm{T}_{4}$ total

Transtirretina

Receptor da vitamina $D$

Transcrito específico para inativação do $X$ 


\section{SUMÁRIO}

1. INTRODUÇÃO

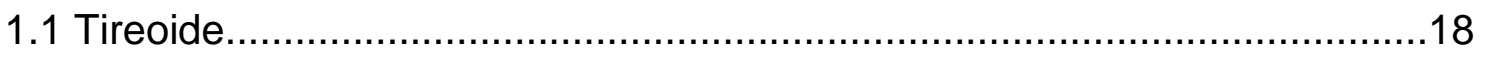

1.1.1 Visão geral da anatomia e histologia da glândula tireoide........................18

1.1.2 Síntese, secreção, transporte e metabolização dos hormônios

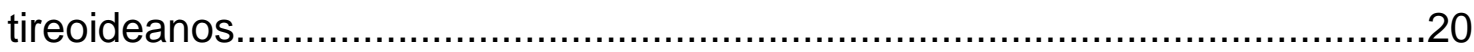

1.1.3 Mecanismo molecular de ação dos hormônios tireoideanos....................28

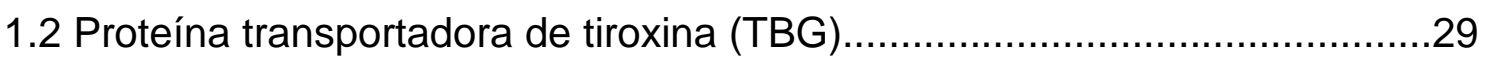

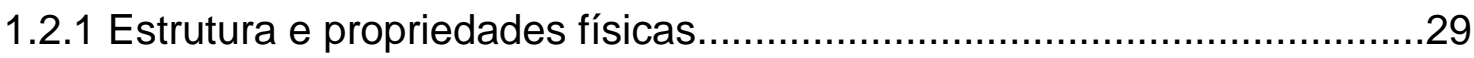

1.2.2 O gene da TBG e sua regulação transcricional......................................34

1.2.3 Propriedades biológicas e Fisiologia da TBG......................................36

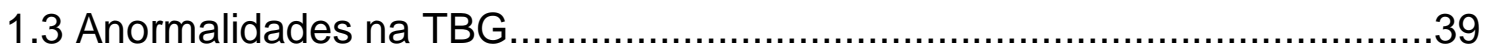

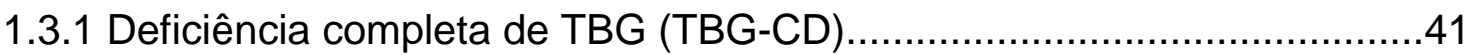

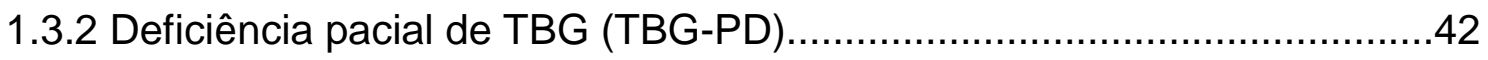

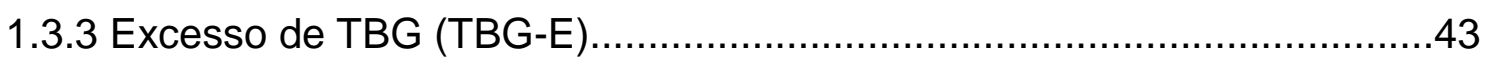

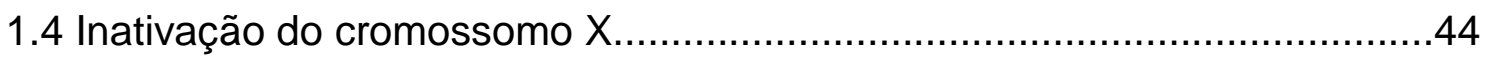

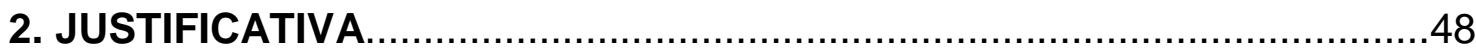

3. OBJETIVOS

4. MÉTODOS

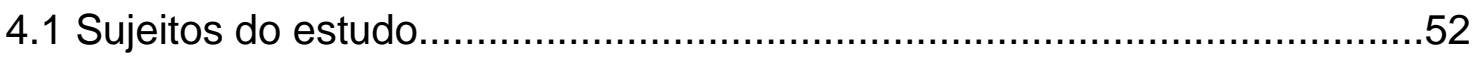

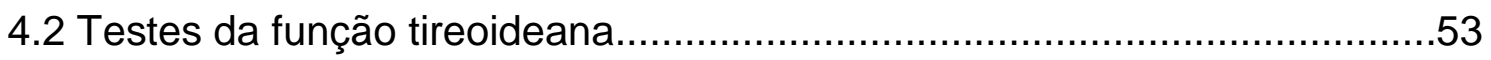

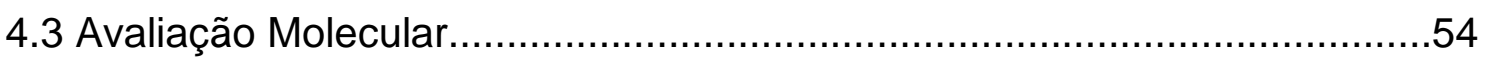

4.3.1 Extração do DNA genômico de leucócitos do sangue periférico...............54

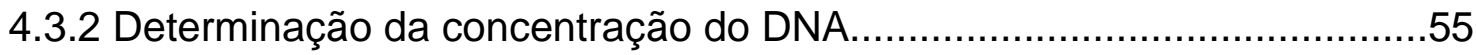

4.3.3 Reação de polimerização em cadeia (PCR) .........................................5

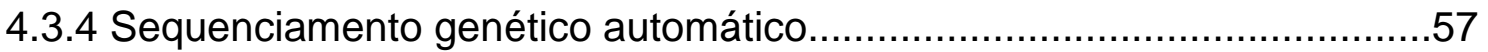

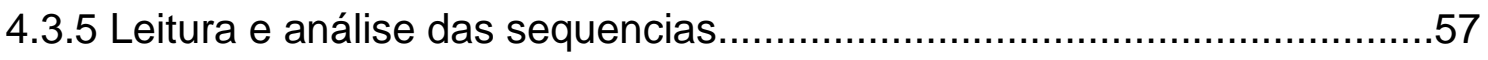

4.3.6 Análise de preditiva in silico...............................................................57

4.4 Avaliação do Padrão de Inativação do Cromossomo X...............................58

4.4.1 Digestão do DNA pela enzima Hhal.................................................58

4.4.2 Amplificação e eletroforese em gel de agarose....................................59

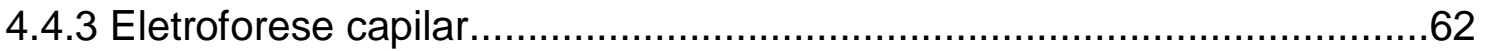


4.4.4 Cálculo da taxa de inativação.

62

4.5 Análise estatística da família da proteínas serpinas e modelagem molecular da proteína mutante .63

5. RESULTADOS

6. DISCUSSÃO

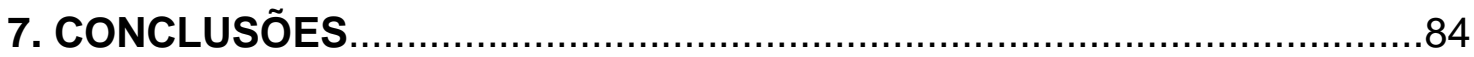

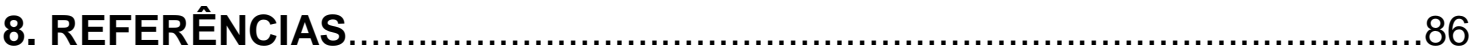

9. APÊNDICES

10. ANEXOS 
INTRODUÇÃO 


\section{INTRODUÇÃO}

\subsection{Tireoide}

\subsubsection{Visão geral da anatomia e histologia da glândula tireoide}

A glândula tireoide é a primeira glândula endócrina a se desenvolver no embrião (1). Sua formação se inicia cerca de 24 dias após a fertilização, a partir de um espessamento endodérmico mediano no assoalho da faringe primitiva (2). Histologicamente, essa glândula é composta por um grande número de unidades esféricas muito próximas entre si, denominadas de folículos, com camada simples de células foliculares, que no interior dos quais há o coloide (substância secretora gelatinosa), constituído principalmente pela proteína tireoglobulina (tg), uma grande glicoproteína que possui cerca de 115 resíduos de tirosina, que são os principais substratos a se combinarem com o iodo para formar os hormônios tireoidianos (3). Além dos folículos, o tecido tireoideano contém células parafoliculares, ou células $C$, que são fontes de calcitonina, um hormônio importante na homeostase do cálcio (Figura 1) (4).

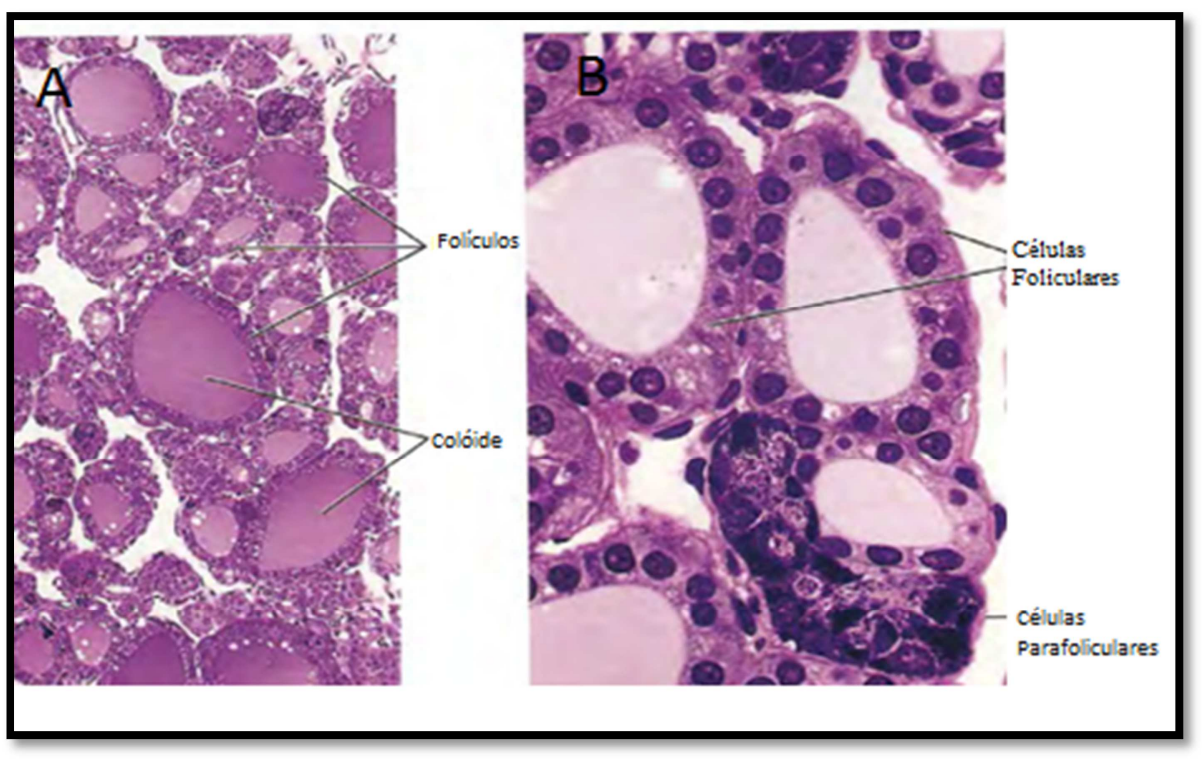

Figura 1 - Corte histológico da tireoide. A. Corte histológico de uma tireoide mostrando os folículos tireoideanos, preenchidos por coloide. B. Corte histológico de uma tireoide mostrando os folículos formados por células foliculares e parafoliculares. Pararrosanilina - toluidina, aumento pequeno e médio, respectivamente. Fonte: Junqueira LCU \& 
Carneiro J. Histologia básica: texto e atlas. 12.ed. Rio de Janeiro: Guanabara Koogan, 2013.

A tireoide é uma das maiores glândulas endócrinas, pesando de 15 a 20 gramas em adultos. Na visão anterior, essa glândula lembra o formato de borboleta, onde dois lobos lateralizados, direito e esquerdo, estão unidos por um istmo de parênquima glandular que se apoia frouxamente sobre a traqueia anterior na altura da cartilagem cricoide (Figura 2). A avaliação clínica da glândula é feita pela palpação da região cervical. A tireoide apresenta um fluxo sanguíneo de $4-6 \mathrm{~mL} / \mathrm{min}$, e devido

a

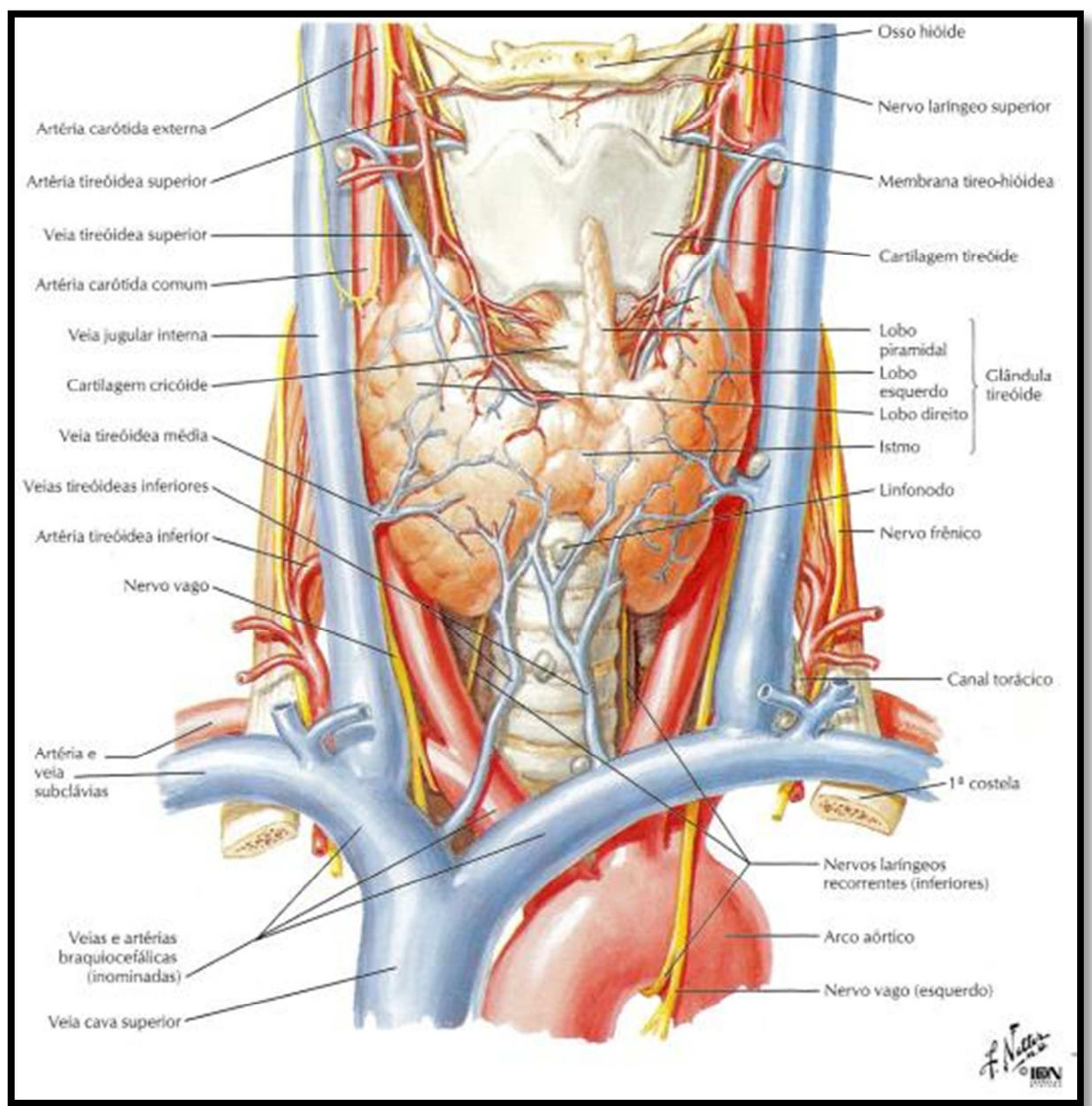

essa rica vascularização, a glândula exibe uma coloração avermelhada (1). 
Figura 2 - Aspectos anatômicos da glândula tireoide, mostrando principalmente os lobos direito e esquerdo da tireoide. Fonte: Raffa RB, Rawls SM, Beyzarov EP. Atlas de Farmacologia de Netter, Porto Alegre: Artmed, 2006.

\subsubsection{Síntese, secreção, transporte e metabolização dos hormônios tireoideanos.}

Os hormônios tireoideanos (HTs) têm efeitos moduladores importantes durante os processos metabólicos de desenvolvimento, crescimento, diferenciação e na manutenção da homeostase metabólica de vários órgãos e tecidos de vertebrados, sendo assim, necessários para o funcionamento normal de quase todos os tecidos, tanto durante o período de desenvolvimento como após o nascimento. Além disto, está bem documentado na literatura que os HTs regulam o consumo de oxigênio, temperatura corporal e frequência cardíaca, como também o metabolismo de carboidratos, proteínas e lipídeos. Por esta razão são considerados essenciais para a manutenção da qualidade de vida (5-9).

Os HTs são produzidos na glândula tireoide em um processo que envolve o transporte ativo do iodo para dentro do folículo por meio do 
transportador transmembrana específico (NIS), sua oxidação e incorporação em resíduos de tirosina na molécula de tireoglobulina (10). A principal forma do hormônio tireoideano (pró-hormônio) secretado pela glândula tireoide é a 3,5,3',5'-tetra-iodo-L-tironina (tiroxina ou $\mathrm{T}_{4}$ ), sendo o único que se origina somente da secreção direta pela glândula tireoide, e uma menor porção é secretada como 3,5,3'-tri-iodo-L-tironina (triiodotironina ou $T_{3}$ ), a forma biologicamente ativa do hormônio (11). Ambos são tironinas iodadas que contêm de quatro a três átomos de iodo, respectivamente, e são formadas pelo acoplamento oxidativo das iodotirosinas precursoras monoiodotirosina e diiodotirosina (MIT e DIT) na molécula de tireoglobulina. A liberação dos hormônios é feita por meio da endocitose e digestão lisossomal da tireoglobulina na célula folicular (12).

Em condições normais, aproximadamente $80 \%$ do $\mathrm{T}_{3}$ é derivado dos tecidos periféricos pela remoção enzimática de um átomo $5^{\prime}$ iodeto (anel externo ou 5 'monodeiodinação) do $T_{4}$, por meio das desiodases tipo 1 (D1) e tipo 2 (D2) (13). A glândula tireoide libera também pequenas quantidades dos precursores monoiodotirosina e diiodotirosina, e de 3,3',5' triiodotironina ou $T_{3}$ reverso $\left(\mathrm{rT}_{3}\right)$, que possui um átomo de iodo no anel interno e dois no externo,

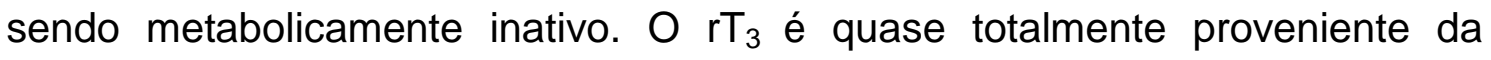
metabolização periférica do $T_{4}$ pela ação da desiodase tipo 3 (D3). $O$ total plasmático de $\mathrm{T}_{4}$ é aproximadamente 45 vezes maior que o de $\mathrm{T}_{3}$ (90nM versus $2 n M)$, o qual apresenta uma atividade biológica superior à $T_{4}$, em cerca de 4-10 vezes mais potente (Figura 3$)(14-16)$. 


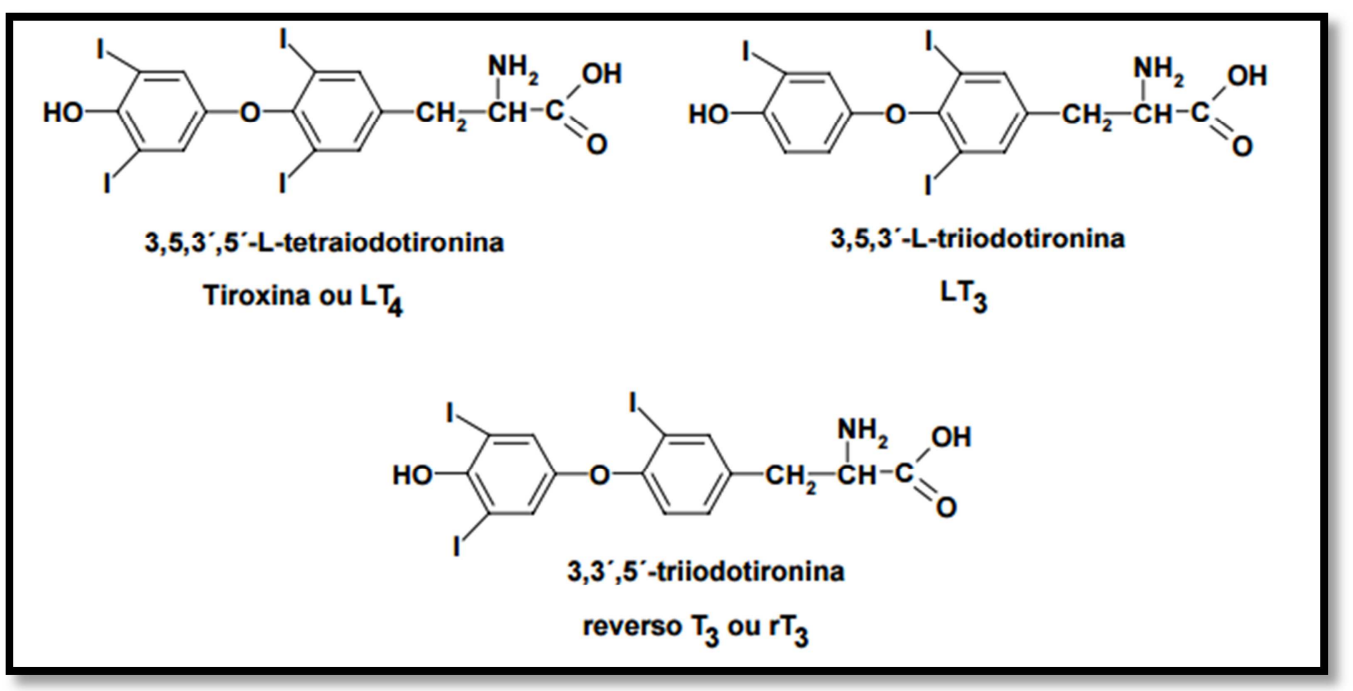

Figura 3 - Fórmulas químicas estruturais dos hormônios tireoideanos e dos compostos relacionados. Fonte: Carvalho, MB. Tratado de Tireoide e Paratireoide. Rio de Janeiro: Rúbio, 2007.

As iodotironinas desiodases tipos I (D1), II (D2) e III (D3) formam uma família de selenoproteínas que, com propriedades catalíticas distintas, ativam ou inativam o hormônio tireoidiano via desiodação do anel externo, fenólico ou tirosínico das iodotironinas (17). Embora as três desiodases apresentem em comum certas características estruturais importantes, essas enzimas diferem entre si em vários aspectos como no padrão de expressão tecidual, localização celular, papel fisiológico, preferência pelo substrato, sensibilidade a inibidores e na forma como são reguladas pelos hormônios tireoidianos (18).

A atividade das desiodases é regulada por um processo complexo, e vários fatores e/ou situações fisiopatológicas podem alterar a desiodação em um determinado tecido. De fundamental importância regulatória são as alterações no status dos hormônios tireoidianos, que determinam mudanças significativas na atividade das desiodases. Assim, uma fina regulação é exercida pelas enzimas desiodases, que ativam e inativam os HTs no seu próprio local de ação. A via de ativação acontece pela desiodação no anel fenólico da molécula de $T_{4}$, que resulta na formação de $T_{3}$, que é catalisada pela $D 1$ e D2. Por outro lado, tanto $T_{4}$ quanto $T_{3}$, podem ser inativados pela desiodação do anel tirosil (interno), pela enzima $D 3$, formando $r T_{3}$ e $T_{2}$, respectivamente. Do ponto de vista fisiológico, estas mudanças parecem coordenadas de forma a manter os níveis circulantes e intracelulares de $T_{3}$ 
próximos do normal. Além de serem expressas em vários tecidos periféricos, as isoenzimas D1 e D2 são amplamente encontradas na tireoide, especialmente na célula folicular $(21,22)$ (Tabela 1).

Tabela 1 - Principais características das iodotironinas desiodases.

\begin{tabular}{|c|c|c|c|}
\hline Características & D1 & D2 & D3 \\
\hline Localizaçāo do gene & Cr. 1p32-p33 & Cr. $14 \mathrm{q} 24.3$ & Cr. $14 \mathrm{q} 32$ \\
\hline Peso molecular (kDa) & 27 & 30 & 31 \\
\hline Papel fisiológico & $\begin{array}{c}\text { Fornece T3 para } \\
\text { o plasma }\end{array}$ & $\begin{array}{l}\text { Fornece T3 para o } \\
\text { espaço intracelular }\end{array}$ & Inativa T3 e T4 \\
\hline Localizaçāo & Figado, rim, tireóide & $\begin{array}{l}\text { Hipófise, cérebro, } \\
\text { tecido adiposo } \\
\text { marrom, placenta, } \\
\text { tireóide, músculos } \\
\text { cardiaco e esquelético }\end{array}$ & $\begin{array}{l}\text { Útero, placenta, tecidos } \\
\text { fetais, pele, cérebro } \\
\text { e hipófise }\end{array}$ \\
\hline $\begin{array}{l}\text { Preferência pelo } \\
\text { substrato }\end{array}$ & $r T 3 \gg T 4>T 3$ & $\mathrm{~T} 4>\mathrm{T} 3$ & $\mathrm{~T} 3>\mathrm{T} 4$ \\
\hline
\end{tabular}

Fonte: Adaptado de Meyer ESL, Wagner MS, Maia AL. Expressão das iodotironinas desiodases nas neoplasias tireoidianas. Arq Bras Endocrinol Metab. vol.51 no.5. São Paulo, 2007.

A síntese e a secreção dos hormônios tireoidianos são reguladas pelo TSH (hormônio tireotrófico) por meio de um sistema de retroalimentação negativa, que envolve o hipotálamo, a hipófise e a glândula tireoide (eixo hipotalâmico-hipofisário-tireoideano) (23). O hormônio liberador de tireotrofina (TRH) é um hormônio secretado pelo hipotálamo e estimula os tireotrofos da hipófise anterior a secretarem TSH que, por sua vez, ganha a circulação periférica e, na tireoide, liga-se a receptores específicos, estimulando todas as etapas de síntese de $T_{4}$ e $T_{3}$, bem como a sua liberação pela glândula. Tanto a secreção do TRH quanto a do TSH são reguladas pelos níveis circulantes dos hormônios tireoidianos, secretados pela tireoide em resposta ao estímulo do TSH (16) (Figura 4). 


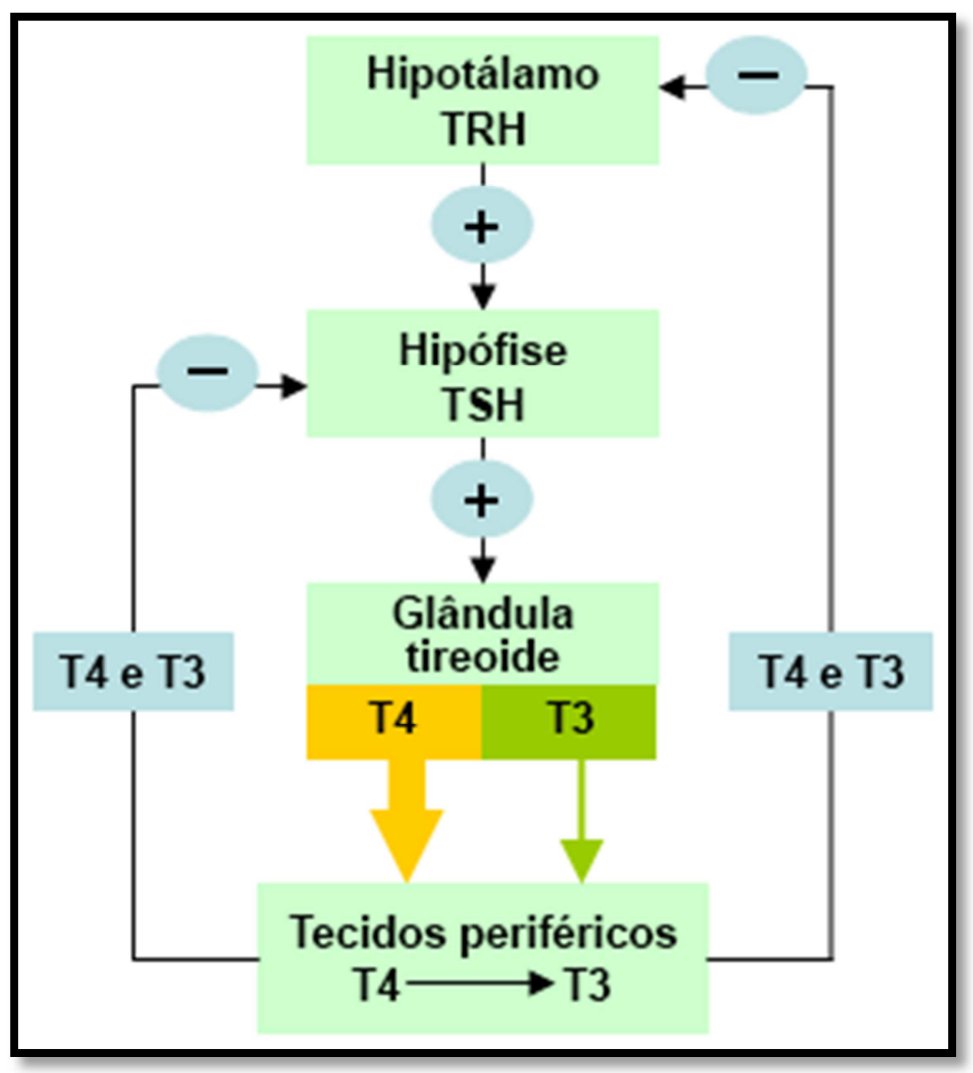

Figura 4 - Representação esquemática do funcionamento do eixo hipotalâmico-hipofisáriotireoideano. O TRH (hormônio liberador de tireotrofina), produzido no hipotálamo, estimula a produção hipofisária de TSH (hormônio tireotrófico). Este, por sua vez, controla todas as etapas da síntese dos hormônios tireoideanos, $T_{3}$ e $T_{4}$. Esses $T H s$ regulam negativamente a síntese de TRH e TSH, exercendo retroalimentação negativa. Fonte: Adaptado de Brent GA. 2012 Mechanisms of thyroid hormone action. J Clin Invest. 2012 Sep;122(9):3035-43

O TRH é um tripeptídeo, piroglutamil histidil prolinamida, responsável pelo estímulo à síntese e à secreção do TSH, e produzido por neurônios parvocelulares situados nos núcleos paraventriculares do hipotálamo médio basal. Estes neurônios se projetam até a eminência média, em que o TRH é liberado em capilares do sistema porta-hipofisário, por meio do qual chega à adeno-hipófise (24). A meia-vida plasmática do TRH é muito curta, variando, aproximadamente, de 2 a 6 minutos em estados de hiper ou hipotireoidismo, respectivamente, uma vez que é rapidamente degradado nos tecidos-alvo e no sangue, pela enzima piroglutamil aminopeptidase, que é altamente específica para o TRH. A atividade desta enzima na hipófise anterior é estimulada pelos HTs (25). Na adeno-hipófise, o TRH atua por meio de receptores específicos na membrana plasmática. Estes fazem parte da grande família dos receptores 
ligados à proteína $\mathrm{G}$ e seu principal mediador intracelular é o cálcio iônico, que ativa a proteína cinase $C(26)$.

O TSH é produzido na adenohipófise, em células denominadas tireotrofos, que correspondem, num indivíduo normal, a aproximadamente 5\% do total de células adeno-hipofisárias. É uma glicoproteína com peso molecular de 28.000 daltons, constituído de duas sub-unidades, $\alpha$ e $\beta$, unidas por ligações não covalentes. As sub-unidades $\alpha$ e $\beta$ são codificadas por genes distintos, localizados nos cromossomos humanos 6 e 1, respectivamente. Em seres humanos aduktos, a concentração sérica de TSH varia entre 0,35-5,5 $\mathrm{mUl} / \mathrm{mL}$. A sua meia-vida é de 30 a 50 minutos e a sua taxa de produção é de 40 a $150 \mathrm{mU} /$ dia ou 100 a $400 \mathrm{mU} /$ dia (3). A secreção de TSH é pulsátil e circadiana. A secreção pulsátil é caracterizada por flutuações no intervalo de 1 a 2 horas. Porém, devido à baixa amplitude destas secreções e ao fato de que a sua meia-vida é relativamente longa, as concentrações séricas de TSH variam muito pouco. Além disso, há uma secreção tônica de TSH, contribuindo para a sua concentração sérica. A magnitude desta flutuação está diminuída em caso de jejum, doenças ou cirurgias. A variação circadiana é caracterizada por um pico noturno que precede o início do sono e parece ser dependente do ritmo do cortisol e das flutuações dos HTs. Se o início do sono for retardado, o pico de TSH torna-se maior e mais prolongado. Efeito oposto ocorre quando se dorme mais cedo (27).

Os hormônios tireoideanos são pouco solúveis em água, assim, após serem secretados, circulam comumente ligados às proteínas plasmáticas, e somente $0,03 \%$ de $T_{4}$ e $0,3 \%$ de $T_{3}$ estão livres. A tiroxina tem uma meia vida longa e uma alta concentração sérica, e essas características são atribuídas aos HTs por se ligarem a três principais proteínas de ligação, que são globulina transportadora de tiroxina (TBG), transtirretina (TTR) e albumina de soro humano (HSA). A ligação do TH em outras proteínas do soro (lipoproteínas de alta densidade) é considerada insignificante e sem importância biológica. Embora HSA seja a mais abundante proteína de ligação aos HTs, a sua afinidade aos HTs é significativamente menor em comparação à TBG. A 
afinidade de TBG aos HTs é 50 e 7000 vezes maior do que ao TTR e HSA, respectivamente (Tabela 2 ).

Desta maneira, essas proteínas funcionam principalmente como um sistema tampão para manter uma grande reserva de TH e uma concentração estável extratireoideana de $\mathrm{T}_{4}$, assegurando, assim, uma distribuição regular do hormônio nos tecidos-alvo $(3,28,29)$.

Tabela 2 - Propriedades e parâmetros metabólicos das principais proteínas transportadoras de hormônios tireoideanos séricos

\begin{tabular}{|c|c|c|c|}
\hline & TBG & TTR & HSA \\
\hline Peso molecular (KDa) & $54^{\mathrm{a}}$ & 55 & 66,5 \\
\hline Estrutura & Monômero & Tetrâmero & $\begin{array}{l}\text { Monômer } \\
\text { o }\end{array}$ \\
\hline Conteúdo de Carboidratos (\%) & 20 & 0 & 0 \\
\hline $\begin{array}{l}\text { Número de sítioS de ligação para } T_{4} \text { e } \\
T_{3}\end{array}$ & 1 & 2 & 4 \\
\hline \multicolumn{4}{|l|}{ Constante de Associação, $\mathrm{K}_{\mathrm{a}}\left(\mathrm{M}^{-1}\right)$} \\
\hline Para $T_{4}$ & $1 \times 10^{10}$ & $2 \times 10^{8 b}$ & $1,5 \times 10^{6 b}$ \\
\hline Para $\mathrm{T}_{3}$ & $1 \times 10^{9}$ & $1 \times 10^{6}$ & $2 \times 10^{5}$ \\
\hline \multicolumn{4}{|l|}{ Concentração no soro } \\
\hline Média Normal (mg/L) & 16 & 250 & 40.000 \\
\hline $\begin{array}{l}\text { Total da Capacidade de Ligação (mg } \\
\mathrm{T}_{4} / \text { Litro) }\end{array}$ & 0,2 & 3 & $>1000$ \\
\hline \multicolumn{4}{|l|}{$\begin{array}{l}\text { Distribuição relativa de } \mathrm{T}_{4} \text { e } \mathrm{T}_{3} \text { no soro } \\
(\%)\end{array}$} \\
\hline Para $\mathrm{T}_{4}$ & 75 & 20 & 5 \\
\hline Para $\mathbf{T}_{3}$ & 75 & $<5$ & 20 \\
\hline Tempo de meia-vida (dias) & $5^{c}$ & 2 & 15 \\
\hline Taxa de degradação (mg/dia) & 15 & 650 & 17.000 \\
\hline \multicolumn{4}{|c|}{$\begin{array}{l}\text { Peso molecular aparente na eletroforese em gel de acrilamida } 60 \mathrm{kDa} \text {. } \\
{ }^{\mathrm{B}} \text { Valor dado para o peso no sítio de alta afinidade. } \\
{ }^{\circ} \text { Mais sobre a influência do estrógeno. }\end{array}$} \\
\hline
\end{tabular}

Na ausência das proteínas plasmáticas de ligação, principalmente a TBG, qualquer diminuição da secreção dos THs pode ocasionar um esgotamento rápido dos hormônios tireoideanos. Nos estados inflamatórios, a TBG pode sofrer alterações conformacionais com consequente diminuição da afinidade aos THs (30). Anormalidades nas proteínas de ligação aos THs não resulta em disfunção da tireoide, mas pode alterar as concentrações séricas dos THs, que podem ser mal interpretados e levar a um tratamento desnecessário. Deficiências hereditárias ou adquiridas na ligação das proteínas 
aos HTs são caracterizadas por hiper ou hipoiodotireoidenemia, enquanto os pacientes são clinicamente eutireoideos (31). No entanto, é possível que outra doença da tireoide, tais como tireotoxicose ou hipotireoidismo, possa estar presente simultaneamente, o que dificultaria ainda mais o diagnóstico (32).

A transtirretina (TTR), previamente conhecida como pré-albumina ligada a tiroxina (TBPA), transporta $15-20 \%$ do T4 circulante e também auxilia no transporte de retinol, por meio da formação de um complexo com a proteína ligadora de retinol (RPB, do inglês "retinol binding protein"). Ela consiste em quatro cadeias polipeptídicas idênticas com 127 subunidades de aminoácidos, com uma massa molecular total de aproximadamente $55 \mathrm{kDa}$, altamente acídica e não é glicosilada. Normalmente, sua meia-vida no plasma é de aproximadamente dois dias, com redução durante a doença (Tabela 2). A TTR é expressa no plexo coroide, sendo a principal proteína de ligação aos hormônios tireoideanos no fluido cérebro-espinhal (CSF) (33).

A albumina, proteína mais abundante na circulação sanguínea, é constituida de uma única cadeia polipéptidica contendo 585 aminoácidos carregada negativamente com massa molecular de $66,5 \mathrm{kDa}$ e sintetizada no fígado (34). Sua principal função é manter a pressão coloideosmótica estável. Por outro lado, desempenha um papel importante na ligação e no transporte de um grande número de compostos endógenos (incluindo THs) e exógenos, formando, assim, um depósito circulante por ligantes e prolongando a sua meia-vida. Apesar de uma alta capacidade de ligação, a afinidade da HSA para T4 é quase 7.000 vezes menor do que para TBG (Tabela 2). Do ponto de vista fisiológico, até mesmo alterações extremas de concentração de HSA, tais como deficiência total de albumina, não resulta em mudanças significativas dos níveis de THs. Assim, mesmo em alta concentração no sangue, essa proteína resulta em torno de $15 \%$ de ligação do total de hormônios tireoideanos no plasma (35).

A entrada e a saída dos HTs nas células ocorrem, em uma menor parcela, por difusão passiva (36), e outra principal por meio de transportadores específicos que regulam a captação e efluxo (37-40). A ação dos HTs ocorre, fundamentalmente, por meio da ligação do hormônio a seus receptores nucleares (TRs), que são proteínas nucleares ligadoras de $T_{3}$, localizados em sequências específicas, os elementos responsivos ao hormônio tireoideano 
(TREs), na região promotora dos genes-alvos. Estes podem ativar ou reprimir genes alvos pela ligação direta ao elemento responsivo ao DNA como homo ou heterodímeros ou pela ligação de outras classes de fatores de transcrição ligados ao DNA. Essa atividade tem sido relacionada à formação de complexos com moléculas que parecem servir como co-ativadoras ou co-repressoras, causando modificação local da estrutura da cromatina para regular a expressão desses genes específicos $(8,41,42)$.

Dentro da superfamília dos receptores nucleares, a subclasse de receptores não esteroidais ou tipo II que abrange os hormônios tireoideanos, o ácido retinoico (RAR), a vitamina $D(V D R)$ e os proliferadores peroxissomais (PPAR), possuem uma estrutura composta por módulos funcionais, relativamente conservados entre os membros da superfamília, e que permitem a ligação destes receptores aos seus respectivos hormônios e sequências específicas de nucleotídeos no promotor de genes-alvo regulados pelo hormônio (43-45). Essas sequências específicas no DNA foram denominadas de elementos responsivos ao hormônio que geralmente estão localizados na região promotora dos genes alvos, além de serem específicos para cada receptor e possuírem duas cópias imperfeitas de um hexanucleotídeo, que podem estar arranjadas em diferentes orientações, com espaçamento e sequências flanqueadoras diferentes $(24,46)$.

Existem dois genes que codificam os TRs: TRa (gene nativo homólogo ao oncogene viral-c-erb A) localiza-se no cromossomo 17 nos humanos, e o outro gene, clonado simultaneamente, o TR $\beta$ localizado no cromossomo 3 (4748). Cada um destes genes codifica várias proteínas ( $\alpha 1, \alpha 2, \Delta \alpha 1, \Delta \alpha 2, \beta 1, \beta 2$, $\beta 3, \Delta \beta 3$ ), que são resultados de um processamento alternativo (splicing) do RNA mensageiro ou da utilização de promotores alternativos desses genes. A expressão deles é diferente em vários tecidos. O TR $\beta 1$, por exemplo é abundante no fígado, rins, cérebro, enquanto o TRa1 é mais expresso nos músculos esqueléticos e miocárdio. Já o TRß2 é quase expresso exclusivamente na hipófise anterior em outras áreas cerebrais (49-50).

Em geral, os receptores nucleares possuem em comum três domínios: um domínio amino-terminal de ligação ao promotor, um domínio de ligação ao DNA altamente conservado (DBD), e um domínio c-terminal menos conservado, de ligação ao ligante (LBD). O domínio de ligação ao DNA é 
essencial para o reconhecimento do elemento responsivo pelo receptor. O LBD confere especificidade na ligação ao ligante e possui um número de funções reguladas por essa ligação. Essas funções incluem a liberação do receptor do complexo, translocação para o núcleo, homodimerização, heterodimerização e ativação transcricional $(47,49,50)$.

\subsubsection{Mecanismo molecular de ação dos hormônios tireoideanos}

Os HTs agem por meio de sua ligação a receptores nucleares que, por sua vez, ligam-se ao DNA, geralmente como heterodímero com receptor retinoide $(R X R)$ em sequências específicas (TREs) por preferências dos sítios de ligação de DNA do complexo RXR-TR (ou TR-TR). Desta forma, na presença do ligante $\left(\mathrm{T}_{3}\right)$, os TRs ligam-se com alta afinidade e promovem alteração tanto da estrutura tridimensional do TR, como na associação a outras proteínas. Ocorre uma série de alterações conformacionais no TR, facilitando a liberação das proteínas co-repressoras e recrutamento de proteínas coativadoras, como SRC-1 (co-ativador 1 do receptor de esteroide), TRAP/DRIP1 (mediador silencioso para TR e RAR). As proteínas co-ativadoras possuem atividade de acetilação das histonas, promovendo o relaxamento da cromatina, que agem sobre a maquinaria de transcrição basal (MTB) ativando a transcrição de genes-alvos $(8,41,51)$ (Figura 5). Já na ausência dos HTs, os TRs ligam-se ao DNA na forma de monômeros, homodímeros, e menos frequentemente como heterodímeros com o receptor de retinóide $(R X R)$ e recrutam um complexo de proteínas co-repressoras como o N-Cor (corepressor do receptor nuclear), o SMRT (mediador silencioso para TR e RAR) que, por sua vez, associam-se a outras proteínas, formando um complexo protéico que mantém a cromatina mais compactada pela desacetilação das histonas que favorece a inibição transcrional (Figura 5) $(52,53)$.

A interação do T3 com seus receptores nucleares leva, portanto, à ativação ou inibição da expressão desses genes-alvo, o que implica no estímulo ou bloqueio da síntese de proteínas específicas, mecanismo pelo qual os HTs exercem os seus efeitos biológicos nas células. Assim, os efeitos dos HTs são importantes para o crescimento normal e desenvolvimento, manutenção da estabilidade metabólica, regulando as necessidades de oxigênio, peso corpóreo e metabolismo. Estimulam diversas atividades 
metabólicas de lipídeos e carboidratos. Atuam por ações diretas e indiretamente, pela modulação das ações da insulina, glucagon (glicogenólise), catecolaminas e glicocorticorticoides. No sistema cardiovascular aumentam a frequência e a contratilidade cardíaca. Além de exercerem também ações extranucleares ou não genômicas, como alterações no citoesqueleto de actina em células gliais, no transporte de solutos pela membrana plasmática e alterações na atividade de algumas ATPases também foram evidenciadas $(6,8,12,36)$.

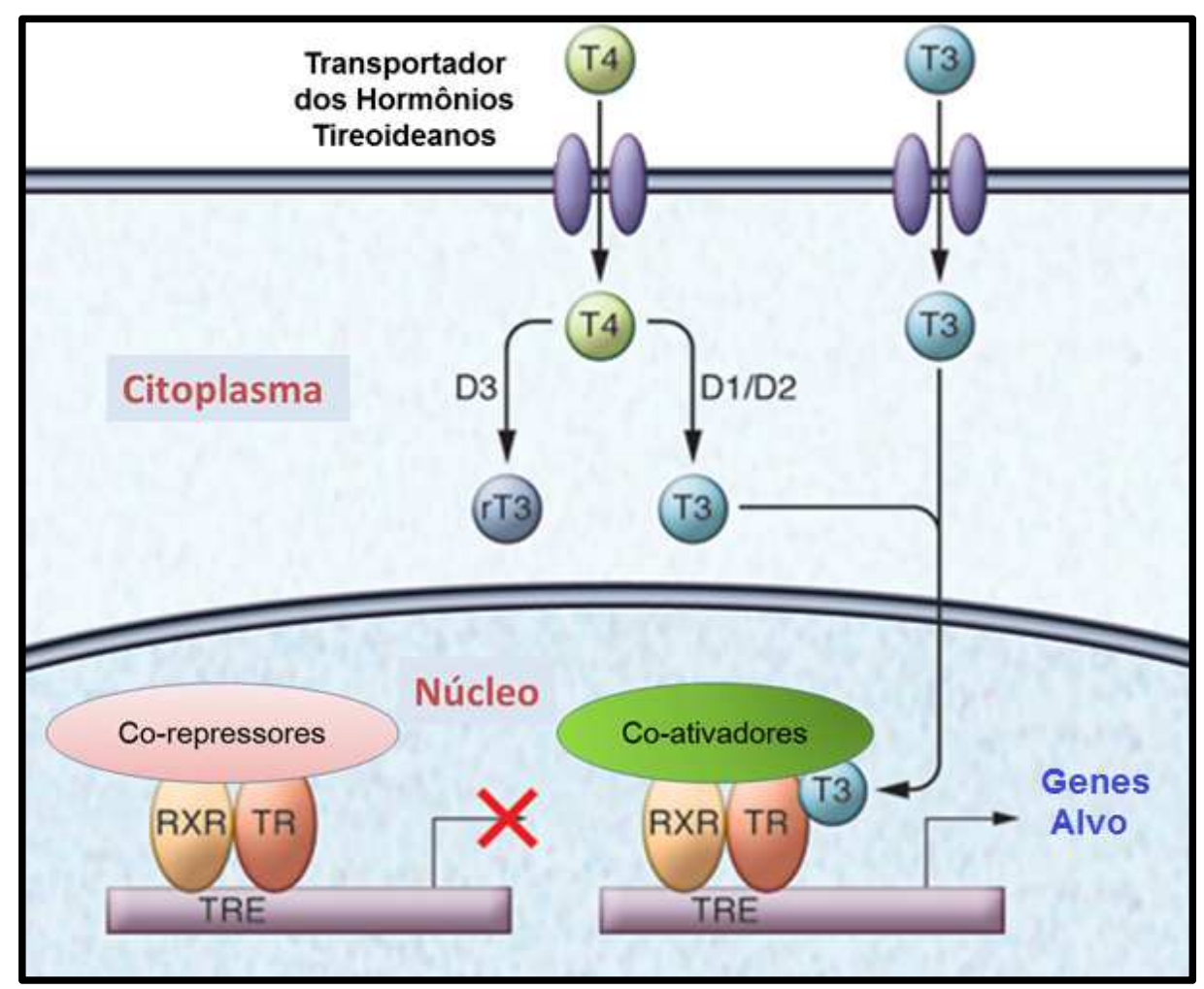

Figura 5 - Ilustração do Mecanismo de ação do Hormônio Tireoideano. Em tecidos específicos, tais como cérebro, transportadores como MCT8 transporta para dentro da célula $T_{4}$ ou $T_{3}$, ou pode entrar no núcleo e se ligar ao receptor do hormônio tireoideano (TR) formando um heterodímero com o receptor do retinoide $(R X R)$ ao elemento resposta ao hormônio tireoideano (TRE), que associado às proteínas co-ativadoras, como SRC-1 e complexo TRAP/DRIP, ativa a transcrição de genes alvo, resultando nos efeitos biológicos do hormônio. Já na ausência de T3, o TR encontra-se ligado ao TRE como homodímeros, e menos frequentemente como heterodímero, e associados às proteínas co-repressoras, como N-CoR e SMRT, reprime a expressão do gene. Fonte: Brent, GA. Mechanisms of thyroid hormone action $\mathrm{J}$ Clin Invest. 2012; 122(9):3035-3043.

\subsection{Proteína transportadora de tiroxina (TBG)}

\subsubsection{Estrutura e propriedades físicas}


A TBG, uma pré-proteína, é uma glicoproteína acídica formada por uma única cadeia polipeptídica contendo 415 aminoácidos e peso molecular de $54 \mathrm{KDa}$, sintetizada no fígado. A TBG é a principal transportadora dos hormônios tireoideanos no sangue, apresenta alta afinidade pela tiroxina $\left(T_{4}\right)$, sendo responsável por $75 \%$ da ligação do $T_{4}$ sérico. Além do $T_{4}$, esta proteína também se liga ao $T_{3}$ e ao $T_{3}$ reverso (54). Sua estrutura primária foi deduzida em 1986 (55) e só após 17 anos sua estrutura cristalográfica foi resolvida em 2006 (56), podendo-se, a partir de então, analisar a interação entre esta proteína e o hormônio tireoidiano.

A molécula madura da proteína (395 aa sem o péptido de sinal) possui quatro unidades de heterossacarídeos com 5 a 9 resíduos de ácido siálico terminal, que são importantes para a correta dobradura pós-tradução e secreção da molécula de TBG $(57,58)$. As cadeias de carbono são responsáveis pela micro-heterogeneidade da TBG quando submetido à focalização isoelétrica (IEF). O ponto isoelétrico da TBG normal varia de $\mathrm{pH} 4,2$ a 4,6, no entanto, este aumenta para 6 quando todos os resíduos de ácido siálico são removidos. O dobramento indevido da molécula ou alterações no núcleo polipeptídeo altera a secreção de TBG, a capacidade de ligação aos HTs e imunoreatividade $(59,60)$.

A proteína é bastante estável no soro, mas rapidamente perde as suas propriedades de ligação por desnaturação a temperaturas acima de $55^{\circ} \mathrm{C}$ e pH abaixo de 4. O tempo de meia-vida de desnaturação da TBG a $60^{\circ} \mathrm{C}$ é cerca de 7 minutos, mas a ligação ao $T_{4}$ aumenta a estabilidade da TBG. A TBG pode ser medida por técnicas de análise de saturação imunométricos ou utilizando um dos seus ligantes iodotironina (61-65).

A TBG pertence à superfamília das serinas inibidoras de protease (serinas, do inglês serine proteinases inhibitors), porém numa forma não inibidora, devido ao alto percentual de identidade e estrutura similar a essa família de proteínas. As serinas são inibidores de proteínas que regulam diversos processos fisiológicos, tais como coagulação, fibrinólise, ativação do complemento, angiogênese, apoptose, inflamação, neoplasia e patogênese viral (66-68).

A maioria das serinas pertence à superfamília da quiomitripsina, a qual inclui enzimas de mamíferos como quimotripsina, tripsina, elastase, calicreína, 
trombina (69). A anti-tripsina é considerada arquétipo estrutural das serpinas. Embora a maior parte pertença ao grupo que inibe as serinas proteases, algumas inibem também caspases, por exemplo. $E$ uma minoria pertence às serinas que não têm função inibitória, como a TBG e a globulina de ligação aos corticosteroides, ambos com função de transporte, ou ainda como supressores tumorais (70-72).

Até o presente momento, a literatura relata que aproximadamente 500 serpinas têm sido identificadas em uma variedade de espécies, incluindo animais, vírus e plantas de tamanhos que variam entre 350-400 aminoácidos e com peso molecular de 40-50 kDa. (73). Todas as serpinas têm sido classificadas dentro de 16 famílias e 10 sequências órfãs (74). E serpinas de vertebrados podem ser classificadas dentro de 6 sub-grupos (75) e formam uma família de grandes glicoproteínas homólogas (69-76). Uma visão geral das serpinas humanas inibidoras e não inibidoras está presente na tabela 3.

Tabela 3. Função, grupo e localização das serpinas humanas classificadas em inibidoras e não inibidoras

\begin{tabular}{|c|c|c|c|c|}
\hline Gene & $\mathbf{X X}$ & Grupo & Função - Alvo & $\begin{array}{l}\text { Localizaçăo } \\
\text { Cromossômica }\end{array}$ \\
\hline \multicolumn{5}{|l|}{ INIBIDORES } \\
\hline a1-antitripsina & A1 & 2 & Elastase & $14 q$ \\
\hline a1-antiquimiotripsina & A3 & 2 & Quimiotripsina & $14 q$ \\
\hline Calistatina & A4 & 2 & Tecido Calicreína & $14 q$ \\
\hline Inibidor de Proteína C & A5 & 2 & Proteína C & $14 q$ \\
\hline Centerina & A9 & $2^{a}$ & Maturação de celulas B novas & $14 q$ \\
\hline $\begin{array}{l}\text { Inibidor de protease proteína Z- } \\
\text { dependente }\end{array}$ & A10 & $2^{a}$ & Fator Xa & $14 q$ \\
\hline Antitrombina III & $\mathrm{C} 1$ & 5 & Trombina, Fator $\mathrm{Xa}$, anti-angiogênico & $6 p$ \\
\hline Heparina co-fator II & D1 & 2 & Trombina, quimiotripsina & $22 q$ \\
\hline $\begin{array}{l}\text { Inibidor-1 ativador } \\
\text { plasminogênio }\end{array}$ & E1 & 3 & Tecido tipo ativador de plasminogênio & $7 q$ \\
\hline a1-antiplasmina & F2 & 4 & Plasmina & $17 q$ \\
\hline Inibidor C1 & G1 & 4 & Complemento $\mathrm{C} 1$ esterase & $11 q$ \\
\hline Neuroserpina & 11 & 3 & $\begin{array}{l}\text { Ativador de plasminogênio, uroquinase, } \\
\text { plasmina }\end{array}$ & $3 q$ \\
\hline Pancrepina & 12 & $3^{a}$ & Repressor tumoral pancreático & $3 q$ \\
\hline \multicolumn{5}{|l|}{ NÃO - INIBIDORES } \\
\hline Globulina de Ligação a Tiroxina & A7 & 2 & Hormônio carreador de $T_{3}$ e $T_{4}$ & $\mathrm{X}$ \\
\hline $\begin{array}{l}\text { Globulina de Ligação a } \\
\text { Corticosteroide }\end{array}$ & A6 & 2 & Hormônio carreador & $14 q$ \\
\hline Angiotensinogênio & A8 & 2 & $\begin{array}{l}\text { Hormônio precursor, regulação da pressão } \\
\text { sanguínea }\end{array}$ & $1 q$ \\
\hline $\begin{array}{l}\text { Fator pigmentante derivado do } \\
\text { epitélio }\end{array}$ & $\mathrm{F} 1$ & 4 & Fator Neurotrófico & $17 q$ \\
\hline $\begin{array}{l}\text { Proteína } 1 \text { de ligação ao } \\
\text { colágeno }\end{array}$ & $\mathrm{H} 1$ & $6^{\mathrm{a}}$ & Molécula de ligação para colágeno & $11 q$ \\
\hline $\begin{array}{l}\text { Proteína } 2 \text { de ligação ao } \\
\text { colágeno }\end{array}$ & $\mathrm{H} 2$ & 6 & Colágeno, Função HSP & $11 q$ \\
\hline Nexina derivada da Glia & $\mathrm{H} 2$ & 3 & Crescimento excessivo na Neurite, trombina & $\mathrm{X}$ \\
\hline \multicolumn{5}{|c|}{$\begin{array}{l}\text { Os nomes clássicos junto à nova nomenclatura (XX, SERPINXX, de acordo com Silverman et al, 2001) é dada. Os } \\
\text { números na coluna "grupo" representam a classificação das serinas em vertebrados dentro dos grupos identificados } \\
\text { pela estrutura do gene e sítios de aminoácidos diagnosticados (Ragg et al., 2001). a A serpina seria classificada para } \\
\text { este grupo pela estrutura básica.Fonte: Adaptado de Gent, DV Sharp P, Morgan K, Kalsheker N. } 2003 \\
\text { Serpins: structure, function and molecular evolution. Int J Biochem Cell Biol. 35(11):1536-47. }\end{array}$} \\
\hline
\end{tabular}


A estrutura protéica da maioria das serpinas, proteínas globulares, é caracterizada por $3 \beta$-folhas (A,B e C) e 8 ou 9 -hélices, nomeadas de hA-hl. (77). As serpinas possuem uma característica importante conservada entre todas as proteínas do grupo que seria uma região $\mathrm{RSL} / \mathrm{RCL}$ (do inglês reactive site loop ou reactive center loop) da alça do centro reativo, localizado em uma área aproximadamente de 20 aa do segmento do peptídeo longo na superfície molecular. Ele está ligado a porção $C$-terminal da cadeia 1 da $\beta$-folha $C$ e na parte $\mathrm{N}$-terminal da cadeia 5 da $\beta$-folha $A$ (Figura 6 ).

Mudanças conformacionais consideráveis ocorrem nas serpinas, sendo chamadas de um mecanismo suicida irreversível, em que a serina protease provoca uma clivagem da serpina na região RCL. Esta clivagem proteolítica dentro do circuíto no centro reativo pela proteinase leva a inserção da cadeia $\mathrm{N}$-terminal para o local de clivagem da cadeia 4 na $\beta$-folha, aumentando para 5 o número de fitas- $\beta$ nessa folha central e ligação covalente entre a serpina e serina-protease. Assim, os complexos resultantes são, entretanto, apenas transientes e colapsam com a liberação de uma forma clivada de diferente estrutura e estabilidade (78-80).

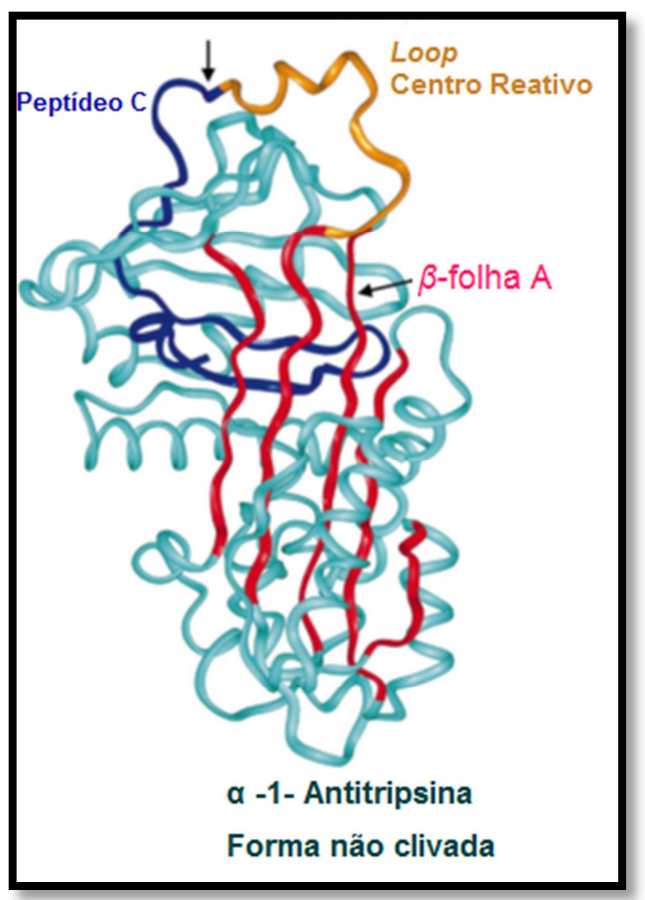

Figura 6 - $\alpha 1$-antitripsina nativa. $O$ centro reativo (amarelo), $\beta$-folha $A$ (vermelho) e porção Cterminal do peptídeo (azul escuro), mostrado em relação ao resto da estrutura que está em azul claro. Fonte: Adaptado de Janciauskiene S. 2001 Conformational properties of serine proteinase inhibitors (serpins) confer multiple pathophysiological roles. Biochimica Biophysica Acta Mar 26;1535(3):221-35. 
A forma nativa é aquela em que o $\mathrm{RCL}$ encontra exposto ao solvente e portanto, passível de interagir com uma serina-protease e disparar o processo de inibição. Já a forma clivada causa deslocamento do RCL e sua inserção na folha A como uma nova fita $\beta$. Com a estrutura tridimensional resolvida (3D) foi possível verificar que os inibidores serpinas possuem dois sítios de interação, sendo um deles responsável pelo reconhecimento da proteinase e outro contendo a alça reativa na qual ocorre à formação do complexo enzima/inibidor propriamente dito (81). Desta maneira, a estrutura terciária da TBG foi resolvida por co-cristalização da molécula não glicosilada sintetizada in vitro com $\mathrm{T}_{4} \mathrm{e}$ corroborou para confirmar supostas propriedades e variantes $(30,56,82,83)$.

A TBG difere dos outros membros da família das serpinas por possuir a metade superior da folha $\beta$ principal completamente aberta. Essa característica permite que peptídeo da região $\mathrm{RCL}$ (alça do centro do reativo) se mova para dentro e para fora da $\beta$-folha $A$ (movimento flip-flop), resultando na ligação e liberação do ligante sem clivagem da TBG (Figura 7) (29). Assim, a molécula pode assumir uma conformação de alta e baixa afinidade, um modelo anteriormente proposto por Grasberger e colaboradores em 2002 (84). Esta reversibilidade é devido à presença exclusiva de prolina P8 na TBG, em vez de uma treonina em todas as outras serpinas, limitando a inserção da alça. Estudos mostram que há uma direta interação entre resíduos $\mathrm{Thr}^{342}$ da alça reativo e Tyr ${ }^{241}$ do sítio de ligação ao hormônio, contribuindo para ligação à tiroxina e liberação subsequente à inserção do sítio reativo. Os movimentos coordenados da alça reativa, hD (Hélice $D$ ) e o sítio de ligação ao hormônio permitem uma regulação alostérica de liberação do hormônio $(29,56)$. 


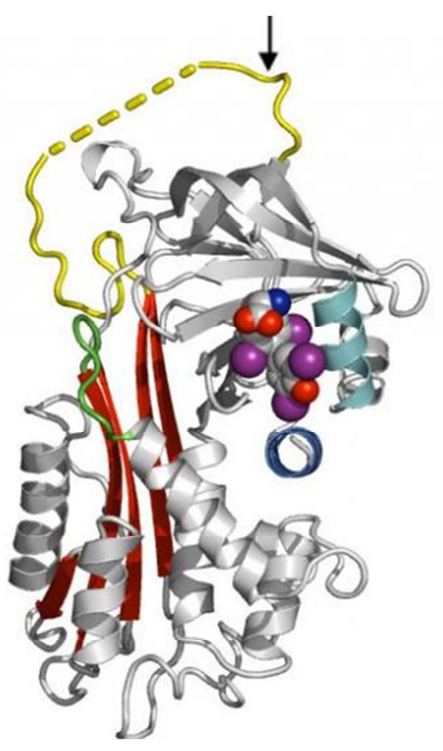

TBG: Intacta Forma S

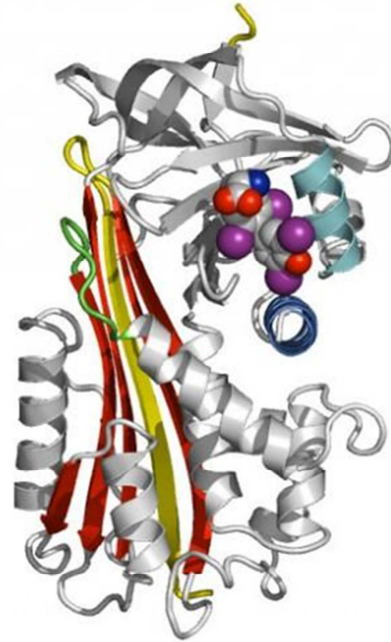

TBG: Clivada Forma R

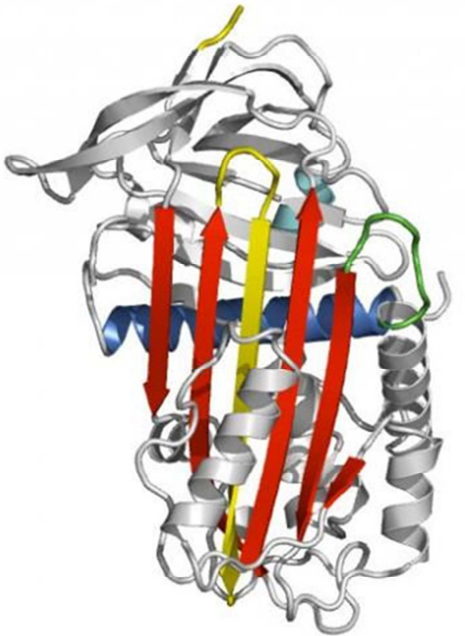

TBG: Vista de cima da Forma R

Figura 7 - Estrutura molecular da TBG: Loops reativos (em amarelo). Inserção ocorre imediatamente após sua clivagem por proteases para se obter uma cadeia extra na folha da molécula, mas o sítio de ligação ao T4 pode ainda manter sua conformação ativa. Isto está de acordo com outros achados que mostram que a ligação e liberação de T4 não é devido a uma mudança, na conformação ligada ou desligada, mas sim do resultado de uma mudança equilibrada de plasticidade do sítio de ligação. Então, a mudança da forma $S$ para $R$ na TBG resulta em uma diminuição em $6 \mathrm{X}$, mas não em uma perda total de afinidade. A liberação de tiroxina é um processo modulado notavelmente visto em resposta às mudanças de temperatura. Fonte: Qi X, et al., Allosteric modulation of hormone release from thyroxine and corticosteroid-binding globulins. J Biol Chem 2011; 286:16163-16173.

\subsubsection{0 gene da TBG e sua regulação transcricional}

O gene que codifica a TBG é denominado SERPINA7 (ou gene TBG), localiza-se no braço longo do cromossomo $X$ (Xq22.2), abrangendo $5.5 \mathrm{~Kb}$ do DNA genômico. O gene SERPINA7 consiste em 5 éxons, sendo o primeiro não codante. O primeiro éxon, chamado de éxon 0 , é pequeno e localizado a 1.62Kbp do primeiro éxon codante (éxon 1), que contém o códon AUG o qual a inicia a tradução. Desta forma, os éxons codantes vão do 1 ao 4 , sendo esta última a região que codifica a região 3'- não traduzida do RNAm da TBG (85).

Os aminoácidos de -20 a -1 compõe um peptídeo sinal, clivado e não presente na proteína em sua forma funcional, porém apresenta um papel importante na tradução pelos ribossomos. A proteína recém-sintetizada é ligada por meio deste peptídeo para a partícula de reconhecimento de sinal, 
que leva o complexo ao retículo endoplasmático. Em seguida ocorre o processamento pós-traducional, que inclui a clivagem do peptídeo sinal, formação de pontes dissulfeto, glicosilação e enovelamento $(55,85)$. Sua sequência de aminoácidos traduzida a partir de cDNA está mostrada na figura 8.

\begin{tabular}{|c|c|c|c|c|c|c|}
\hline-20 & -10 & 10 & 20 & 30 & 40 & 50 \\
\hline \multirow[t]{15}{*}{ MSPFLYLVLL } & VLGLHATIHC & ASPEGKVTAC & HSSQPNATLY & KMSSINADFA & FNLYRRFTVE & TPDKNIFFSP \\
\hline & & 60 & 70 & 80 & 90 & 100 \\
\hline & & VSISAALVML & SFGACCSTQT & EIVETLGFNL & TDTPMVEIQH & GEQHLICSLN \\
\hline & & 110 & 120 & 130 & 140 & 150 \\
\hline & & FPKKELELQI & GNALF IGKHL & KPLAKF LNDV & KTLYETEVES & TDFSNISAAK \\
\hline & & 160 & 170 & 180 & 190 & 200 \\
\hline & & QEINSHVEMQ & TKGKVVGLIQ & DLKPNTTMVL & VNYIHEKAQW & ANPFDPSKTE \\
\hline & & 210 & 220 & 230 & 240 & 250 \\
\hline & & DSSSFLIDKT & TTVQVPMMHQ & MEQYYHLVDM & ELNCTVLQMD & YSKNALALFV \\
\hline & & 260 & 270 & 280 & 290 & 300 \\
\hline & & LPKEGQMESV & EAAMSSKTLK & KWNRLLQKGW & VDLFVPKFSI & SATYDLGATL \\
\hline & & 310 & 320 & 330 & $3 / 40$ & 350 \\
\hline & & LKMGIQHAYS & ENADFSGLTE & DNGLKLSNAA & HKAVLH IGEK & GTEAAAVPEV \\
\hline & & 360 & 370 & 380 & 390 & 395 \\
\hline & & ELSDQPENTF & LHP I IQIDRS & FMLLILERST & RSILFLGKVV & NPTEA \\
\hline
\end{tabular}

Figura 8 - Sequência de aminoácidos traduzida do gene SERPINA7. Os aa numerados de -20 a -1 compõe o peptídeo sinal. A TBG consiste de 395 resíduos de aa e 4 unidades de heterossacarídeos. Fonte: http://www.uniprot.org/uniprot/P05543\#sequences, acesso em 15.04.2016.

Uma classificação arbitrária para todas as serpinas foi proposta por Silverman et al., nomeados como grupos $A-P$, baseado no subtipo da composição sugerida por Irving e colaboradores em 2000 (69, 74). Em 2001, Ragg e colaboradores (75) classificaram ainda em seis subgrupos, identificados pela estrutura do gene e sítios de aminoácidos (Tabela 3). As serpinas humanas são classificadas em nove grupos A - I. Desta forma, a proteína é chamada de SERPINXy, o X é o subgrupo e y é o número dentro do subgrupo. Os maiores grupos são o a1AT-like e os ov-like serpin que são designados " SERPINA " (10 membros) e " SERPINB " (14 membros), respectivamente. Os grupos " SERPINC " e " SERPIND " consistem dos órfãos antitrombina (ATIII) e co-fator II da heparina (HCFII). No total 9 serpinas compõem os grupos SERPIN -I (86). 
O promotor do gene SERPINA7 contém sítios de ligação para vários fatores de transcrição, como os fatores nucleares hepáticos (HNF1a, HNF3a e HNF3 $\beta$ ) conferindo uma forte regulação transcricional fígado-específica (Figura 9) (87). Outra região a $20 \mathrm{kbp}$ abaixo do gene da TBG, isto é que não reside no gene da TBG, também foi recentemente reconhecida por estar envolvida na regulação da expressão do gene $(88,89)$.

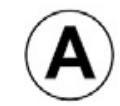

TBG

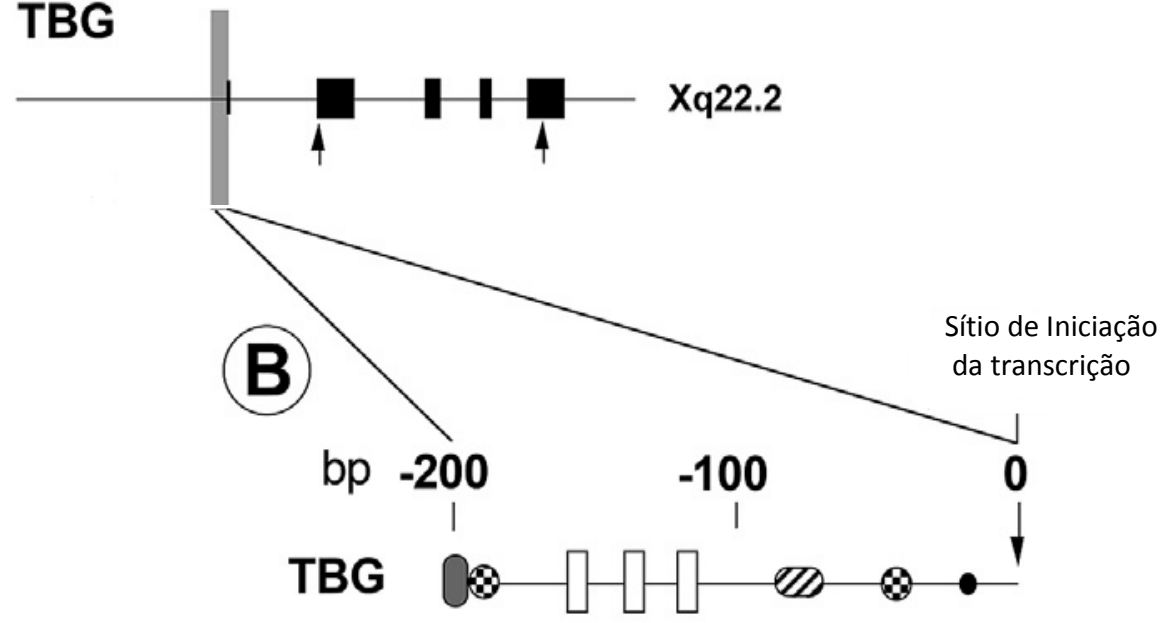

$1 \mathrm{kbp}$

TATAA

HNF-I שO

HNF-3

NF-I

CAAT

or $\theta$

C/EBP

Figura 9 - Organização genômica e localização cromossomal da principal proteína de ligação ao hormônio tireoideano no sangue. A. Cinco caixas representam os éxons. Localização dos códons de iniciação e terminação são indicadas pelas setas. B. Estrutura das regiões promotoras com a localização cis-atuante de elementos regulatórios transcricionais. Adapatado de Pappa T, Ferrara AM, Morkin E, Refetoff S 2015 Inherited defects of thyroxine-binding proteins. Best Pract Res Clin Endocrinol Metab 29(5):735-747.

\subsubsection{Propriedades biológicas e Fisiologia da TBG}

A molécula TBG tem um único sítio de ligação para iodotironina, assim, possui uma afinidade maior para $T_{4}$ vinte vezes maior do que $\circ T_{3}$ (Tabela 3). A capacidade de ligação de $T_{4}$ e $T_{3}$ pela TBG no soro de humanos normais é equivalente à sua concentração, que é aproximadamente $270 \mathrm{nmol} / \mathrm{L}$. 
A meia-vida da proteína no plasma é cerca de 5 dias e o volume de distribuição é semelhante ao da albumina $(61,63,65,90)$. Uma boa atividade de ligação requer a presença da cadeia lateral de L-alanina, um grupo 4'-hidroxil não substituído, uma ponte éter de difenil, e os constituintes de halogênicos $(\mathrm{Br}$ ou I) na posição 3,5,3 'e 5' (91) . A TBG desnaturada não se liga às iodotironinas, mas pode ser detectada com anticorpos que reconhecem a estrutura primária da molécula (61). Em adultos eutireoidianos com concentração normal TBG, cerca de um terço das moléculas transportam $\mathrm{HTs}$, principalmente $\mathrm{T}_{4}$. Quando totalmente saturado, transporta cerca de $20 \mu \mathrm{g}$ de $\mathrm{T}_{4} / \mathrm{dL}$ no soro, e sua via de excreção é pelo fígado (92).

Um grande número de compostos compete com a ligação da TBG a HTs, dentre eles podemos citar: fenitoína, salsalato, furosemida, fenclofenaco, mitotano e salicilatos. Embora a afinidade da TBG por compostos seja menor do que para iodotironinas, se esses estiverem em uma concentração suficientemente alta para competir com $\mathrm{T}_{4}$ e $\mathrm{T}_{3}$ com TTR, podem reduzir os níveis normais do hormônio total, enquanto a fração livre de $T_{4}$ permanece normal. Assim, pacientes eutireoideanos que usam esses fármacos podem parecer ter níveis baixos de $T_{4}$ total e livre, enquanto in vivo o $T_{4}$ livre está normal (3, 93-95).

A ligação e a liberação da tiroxina no sangue são devidas às alterações conformacionais tipo flip-flop da TBG, porém quando ocorre a clivagem da proteína por uma serina protease liberada por leucócitos polimorfonucleares, esta produz uma mudança permanente nas propriedades da molécula. Assim, dados da literatura mostraram que esta forma modificada reduziu a ligação ao T4 e o aumento da estabilidade ao calor (30).

Os intervalos de concentração da TBG no soro de adultos normais são de 1,1-2,1 mg/dL (180-350nM), 14-26 $\mu \mathrm{g} \mathrm{T}_{4} / \mathrm{dL}$ em termos de capacidade máxima de ligação ao $T_{4}$. A proteína está presente no soro por volta da $12^{\text {a }}$ semana de idade fetal e no recém-nascido até 2-3 anos de idade é cerca de 1,5 vezes a concentração de um adulto normal $(55,96-98)$. Os níveis de TBG declinam ligeiramente na metade da idade adulta e tendem a aumentar com 0 avanço da idade (99). A literatura mostra que foram detectados quantidades de TBG, embora inferiores às encontradas no soro, no líquido amniótico (100), fluido cerebrospinal (101) e na urina (85). 
Uma das causas mais comuns do aumento da concentração de TBG no soro é o excesso de estrogênio, seja a partir de uma fonte endógena (tumores produtores de estrogênio) ou exógena (uso terapêutico ou no controle de fertilidade). O nível de várias outras proteínas do soro, tais como globulina de ligação a corticosteroides, globulina de ligação à testosterona, ceruloplasmina e transferrina, também são aumentadas (102). Este efeito estrogênico é mediado por meio do aumento na complexidade dos resíduos de oligossacáridos da TBG em conjunto com uma elevação do número de ácidos siálicos que resultam no prolongamento da meia-vida $(65,103)$. Esteroides anabolizantes e andrógenos produzem um efeito oposto $(56,61)$. Apesar dos hormônios sexuais afetarem o nível sérico de TBG, as diferenças no gênero são pequenas, exceto durante a gravidez, durante o qual as concentrações estão 2,5 vezes o valor médio normal $(104,105)$.

Os hormônios tireoideanos estão associados às proteínas de transporte no soro por ligações não covalentes e estão em constante equilíbrio reversível com a quantidade de hormônio livre $(0,03 \%$ do T4 total e $0,3 \%$ do T3 total) (106). É essa fração livre dos HTs que está imediatamente disponível para os tecidos em que exerce seus efeitos metabólicos $(106,107)$. A TBG é responsável por proteger o organismo contra variações bruscas dos níveis de hormônios tiroideanos, pois funciona como reservatório circulante que libera os hormônios conforme as necessidades locais dos diferentes tecidos. Outra função da TBG é contra o desperdício de iodo por possuir um alto peso molecular que impede a filtração glomerular dos HTs ligados a ela, reduzindo perda do iodo pela urina (108). Além disso, estudos mostram que a TBG facilita a distribuição uniforme de $T_{4}$ celular permitindo que as mudanças na circulação da concentração dos HTs sejam rapidamente transmitidas a todas as células dentro dos tecidos (109). Estudos ainda não concluídos levantam a hipótese de que a TBG executa uma entrega direcionada de HTs. Desta maneira, alterações enzimáticas de sítios específicos na TBG modificariam a sua ligação hormonal, podendo fornecer um mecanismo para direcionar a quantidade de hormônio a ser entregue (110). 


\subsection{Anormalidades na TBG}

Alterações congênitas nas proteínas de ligação dos HTs não são incomuns e podem predominar em alguns grupos étnicos. Em 1959, Beierwaltes e Robbins relataram uma família com excesso de TBG, assim, foi reconhecida pela primeira vez a existência de anormalidades congênitas na TBG no homem (111). Subsequentemente, a ocorrência de deficiências congênitas completas (112-114) e parciais de TBG (115-117) foram descritas. E essas anormalidades na TBG confirmaram o padrão de herança recessivo ligado ao X, com uma única exceção relatada na literatura (118), compatível com a localização do gene da TBG $(119,120)$ e, assim, o fenótipo completo é expresso principalmente no sexo masculino. Desta forma, a hereditariedade também sugere que os defeitos possam ser vinculados ao gene $T B G$ e não apenas da taxa de eliminação da TBG, como há muito tempo tinha sido sugerida como a possível causa (117).

Portanto, anormalidades da TBG podem ser classificadas clinicamente de acordo com o nível de TBG em soro de hemizigotos afetados (homens XY ou mulheres $\mathrm{XO}$, que expressam apenas o alelo mutante) como deficiência completa (TBG-CD) ou parcial (TBG-PD) e excesso de TBG (TBG-E). Em qualquer destas situações a produção de hormônio é normal, mas os testes laboratoriais podem apresentar alterações que sugerem, respectivamente, hipotireoidismo ou hipertireoidismo. Isto significa que, apesar de ser uma condição benigna e que não acarreta disfunção da tireoide, a alteração na quantidade da TBG pode ser erroneamente interpretada e levar a tratamentos desnecessários. Além das alterações quantitativas citadas, também há alterações qualitativas que podem fazer com que a TBG tenha menor afinidade pelos hormônios tireoidianos (121).

Esses defeitos geralmente se manifestam na clínica bioquímicamente como hipertiroxinemia eutireoidea ou hipotiroxinemia e, em raros casos, isolado hipertriodotironinemia. A tirotoxicose, hipotireoidismo, bócio e hiperlipidemia familiar consiste em anomalias que geralmente são coincidentes (122). No entanto, os indivíduos com distúrbios da tireoide são mais propensos a passar por testes mais acurados para uma detecção aleatória de um defeito no transporte hormonal da tireoide (29). 
Geralmente, a deficiência ou o excesso de TBG são diagnosticados pelos achados acidentais anormais de $T_{4}$ sérico e $T_{4}$ livre normal. Assim, quando há ausência de fatores que causam anomalias adquiridas na TBG, deve-se levantar a suspeita de ser defeito herdado da TBG, o que pode ser facilmente confirmada pela presença de anomalias semelhantes na TBG em membros na família. No entanto, a confirmação de defeitos herdados da TBG requer análise genética (123).

Refetoff observou, em 1989, que, nas famílias com TBG-CD, homens afetados não têm níveis detectáveis TBG e mulheres portadoras (mães ou filhas) têm em média a metade da concentração de TBG normal. Nas famílias com homens com TBG-PD, a concentração média TBG em mulheres heterozigotas é geralmente acima da média normal. A concentração sérica de TBG em homens com TBG-E é de 2 a 4 vezes maior em relação ao valor médio normal, e nas mulheres portadoras correspondentes, o valor é um pouco maior do que o valor médio nos homens afetados. Estas observações indicam igual contribuição de células que expressam os genes mutantes e normais para TBG. Em raras ocasiões, a inativação seletiva do cromossomo $X$ tem sido a causa da manifestação do defeito completo da proteína (fenótipo hemizigótico) em mulheres heterozigotas (124).

Além dessas observações relatadas, os defeitos herdados na TBG podem ser devido ao nível de TBG desnaturada (dnTBG) no soro e decorrente das propriedades físico-químicas da molécula, que podem ser: (A) identidade imunológica; (B) o padrão focagem isoelétrica (IEF); (C) taxa de inativação quando exposta as várias temperaturas e ao $\mathrm{pH}$; e (D) a afinidade para ligantes, $T_{4}$ e $T_{3}$. Assim, a identificação mais precisa dos defeitos TBG requer sequenciamento do gene da TBG (29).

Até o presente momento, 51 variantes de TBG foram identificadas, e dentre essas, 49 foram geneticamente caracterizadas (29) 


\subsubsection{Deficiência completa (TBG-CD)}

TBG-CD é definida como níveis indetectáveis de TBG no soro de indivíduos hemizigotos afetados ou com um valor menor do que $0,03 \%$ da média normal. Os limites atuais de detecção utilizando o ensaio mais sensível, radioimunoensaio (RIA), é de $5 \mathrm{ng} / \mathrm{dL}$ (125). TBG-CD foi identificada pela primeira vez em uma adolescente de 13 anos de idade com síndrome de Turner, ausência completa de TBG, similar aos membros da família do sexo masculino afetados. Os dados laboratoriais encontrados nessa paciente foi uma baixa concentração de T4 no soro, e achados clínicos como a baixa estatura, levando ao tratamento com doses crescentes de $\mathrm{TH}$, resultando em efeitos adversos como agitação e sono perturbado, além da diminuição do desempenho escolar (114). A publicação dessa família em 1968 foi de grande importância, pois foi a partir desta que a causa do defeito na TBG foi identificada.

A prevalência da deficiência completa de TBG é de aproximadamente 1:15.000 nascidos do sexo masculino. Há uma variação étnica nos dados de prevalência, sendo que a deficiência completa é mais comum em japoneses (1:1.200 a 1:1.800) do que em brancos (1:5.000 a 1:13.000) (123).

Vinte e sete variantes da TBG tendo esse fenótipo foram caracterizadas geneticamente e dezoito dessas possuem moléculas truncadas, produzidas pela substituição de um único nucleotídeo ou deslocamento do quadro de leitura, frameshifts, devido a deleções nucleotídicas. A terminação antecipada da tradução dessas variantes é causada em 4 por uma única substituição de nucleotídeo (TBG-CDP1, TBG-CDP2, CD5, TBG-CDB e TBG-CDT2) ou por um frameshift devido a uma deleção de um único nucleotídeo (TBG-CDY, TBGCDN, TBG-CDNI, TBG-CD6, CD-PL, TBG-CD7, TBG-CD8, e TBG-CDJ, TBGCDPE) ou deleção de 19 nucleotídeos (TBG-CDH) (29).

Em 7 variantes, mutações foram descritas nos íntrons dentro do sítio de splice causando frameshift (TBG-CDK) ou splicing completo do éxons (TBG-CDL e TBG-CDja). Em contraste, substituições nucleotídicas no sítio de splicing 5' dentro intron IV (TBG-CDL e a TBG-CDja), resultou em um splicing completo do éxon 3 , e também produziu uma molécula truncada (126). Uma 
substituição de um único aminoácido foi a causa de TBG-CD em cinco famílias (TBG-CDT1, TBG-CDPA, TBG-CD5, TBG-CDP3 e TBG-CDKo), entretanto devido à baixa sensibilidade nos exames, podem ter sido classificadas erroneamente. Em TBG-CD5, a Leucina na posição 227 substituída por uma prolina, foi relatada provocar um processamento pós-traducional aberrante (127). Uma variante TBG (TBG-CDNI), com dois nucleotídeos deletados perto da região carboxílica terminal, resultou em mutação frameshift na extensão da molécula por adição de 7 resíduos nonsense (128). TBG-CDMi foi recentemente encontrada em associação a mutações P453A no gene THR $\beta$ (129). TBG-CDJ até o presente momento foi identificada apenas em japoneses, mas a frequência do seu alelo na população permanece desconhecida, embora já sejam bem documentadas que algumas mutações no gene SERPINA7 têm maior prevalência em determinados grupos étnicos $(130,131)$.

\subsubsection{Deficiência parcial (TBG-PD)}

A deficiência parcial TBG é mais comum do que a deficiência completa, com uma prevalência de 1:4.000 nascimentos. Alta frequência de variantes na TBG foram identificados em negros africanos, aborígenes australianos e esquimós (132). Uma vez que um número de variantes da TBG circula em baixas concentrações, é muito provável que diferentes mecanismos possam levar à deficiência parcial de TBG. A redução da secreção pode ser devido a alterações na expressão do gene ou processamento intracelular anormal ou ainda, taxa de degradação acelerada devido à instabilidade das moléculas variantes. Em geral, variantes TBG que são mais instáveis ou susceptíveis à desnaturação pelo calor são encontradas em menor concentração em soro. (29). Algumas variantes instáveis podem ter menor afinidade de ligação para THs ou padrões de migração anormais na eletroforese de IEF. Mutações com diminuição da afinidade para $T_{4}$ e $T_{3}$ possuem uma redução desproporcional na concentração do hormônio em relação ao nível correspondente de TBG no soro (133).

Os homens com deficiência hereditária de TBG que têm níveis de TBG detectáveis no soro são classificados como parcialmente deficientes de TBG. Enquanto, pelo critério, indivíduos hemizigotos afetados devem possuir 
concentrações séricas de TBG abaixo do limite inferior. Assim, uma definição normal mais ampla de deficiência parcial de TBG engloba todas as anomalias hereditárias da TBG resultando em níveis séricos de TBG que são, em média, significativamente abaixo do valor médio para os homens não afetados em um mesmo grupo populacional. Desta forma, por esta definição, os sujeitos com deficiência parcial de TBG podem ter níveis de TBG com sobreposição aos valores normais (32). Esta condição pode ser muito comum, especialmente se inclui uma variante como grupos étnicos distintos. Por exemplo, cerca de metade da população australiana aborígena expressa uma forma de TBG (TBG - A) que, além de ter baixa afinidade para os HTs, está presente no soro em concentrações mais baixas do que a TBG-C $(104,134)$.

Os níveis de TBG no soro em mulheres heterozigotas muitas vezes se sobrepõem ao nível normal, sendo encontrado acima da média normal. Contrariamente ao TBG-CD, todos TBG-DP são causadas por mutações missense. TBG-CDs com mutações missense podem ter sido erroneamente classificados devido à baixa sensibilidade dos ensaios de rotina de medição TBG (29).

\subsubsection{Excesso de TBG (TBG-E)}

O excesso de TBG é uma condição menos frenquentemente encontrada de forma herdada e mais comumente vista como forma adquirida como, por exemplo, na gravidez, em tratamentos com estrógenos e na hepatite. $O$ estrogênio em excesso é a causa mais comum de aumento da concentração de TBG no soro, mediada pela meia-vida prolongada da TBG (32).

TBG-E tem uma prevalência mais baixa do que a deficiência de TBG. Valores obtidos a partir de resultados em programas de triagem neonatal foram bastante variados: de 1:6.000 a 1:40.000. No estado de Nova lorque (135) foi visto uma prevalência de 1:6.000, de 1:17.800 na Nova Zelândia (136), e 1:6.000 em Birmingham, Reino Unido. (137). Embora a prevalência possa variar entre grupos étnicos, a julgar pelo número relativamente baixo de relatos publicados em famílias com excesso TBG, é possível que a causa da elevação TBG em algumas das lactantes não foi necessariamente genética. Este tem sido tema de uma pesquisa em neonatos, realizado na providência canadense 
de Quebec, mostrando que em 12 de 15 crianças com altas taxas de TBG foi apenas transitória (138). Desta maneira, esse achado reduziu o cálculo da incidência de excesso TBG hereditária, comprovado para 1: 25.000. (29).

Os níveis de TBG no soro em indivíduos afetados, hemizigóticos, variaram de 3 a 4,5 vezes a média normal e os níveis de $T_{4}$ médios de 2,5 vezes a média normal (121). Assim, não é surpreendente que as concentrações $T_{4}$ em condições normais estejam altas em recém-nascidos, em valores acima dos níveis em adultos, nas crianças com TBG herdada em excesso (139). Em 1995, Mori e colaboradores demostraram que a amplificação da parte do gene SERPINA7 era a causa forma da hereditária da TBG-E (140).

\subsection{Inativação do cromossomo $X$}

O cromossomo $X$ possui cerca de 155 milhões de pares de bases, aproximadamente 1.155 genes e, entre eles, 868 foram identificados como codificadores de proteínas. Essas proteínas possuem diversas funções estruturais e participam da regulação da transcrição de outros genes e da transdução de sinais; a maioria atua no núcleo e no citoplasma, porém podem também exercer sua função em organelas, na membrana plasmática e no meio extracelular (141).

A teoria da inativação do cromossomo $X$ nas células somáticas femininas normais ocorre como mecanismo de compensação de dose dos produtos gênicos entre os sexos feminino e masculino. De acordo com a hipótese de Lyon (1961), existe nas células de mamíferos do sexo feminino apenas um cromossomo $X$ ativo (142). Isto proporciona essa compensação de dose entre homens $(X Y)$ e mulheres $(X X)$ em relação aos genes presentes no cromossomo $X$. Essa inativação do cromossomo $X$ ocorre no início da vida embrionária, por volta do $13^{\circ}-16^{\circ}$ dias de vida intra-uterina e possue duas propriedades importantes. A primeira propriedade é a determinação randômica (aleatória): $\circ \mathrm{X}$ de origem materna e $\circ \mathrm{X}$ de origem paterna têm a mesma probabilidade de serem escolhidos para inativação. A segunda é a manutenção do padrão de inativação, em que a partir do momento em que um dos 
cromossomos $X$ é escolhido para inativação e é inativado, todos os descendentes clonais daquela célula apresentam o mesmo $X$ inativo. Desta forma, a inativação do $\mathrm{X}$ é um processo determinado aleatoriamente e clonal, mas fixo $(142,143)$.

Uma das consequências do processo de inativação do $X$ é a ocorrência de mosaicismo somático em mulheres, já que estas possuem 2 populações celulares distintas em relação ao cromossomo $\mathrm{X}$. Disso resulta que, em média, as mulheres possuem $50 \%$ das suas células somáticas com 0 cromossomo $X$ materno ativo e nos outros $50 \%$ o cromossomo ativo é o paterno. São, assim, mosaicos quanto à inativação do cromossomo $X$ e se distribuem de acordo com uma curva normal quanto à porcentagem de células com o cromossomo $X$ materno ou paterno inativos, como demonstrado em estudo de 415 mulheres adultas da população geral (144). Os autores verificaram que apenas $1,7 \%$ dessas mulheres tinham padrão de inativação com desvio completo (100:0) e concluiram que uma mulher qualquer da população, que tenha tal padrão de inativação, tem probabilidade pelo menos igual de ser portadora ou não de mutação no cromossomo $X$ que afeta a razão de inativação, justificando a investigação de patologias com herança ligada ao X na família (143).

Existem algumas situações em que a inativação do $X$ não é aleatória, como, por exemplo, circunstâncias em que há uma mutação presente em um dos cromossomos $X$, a seleção ocorre no cromossomo $X$ onde há defeito, permitindo a seleção de $X$ ativos sem mutação e tendo, portanto, um efeito benéfico. Ou ainda quando uma inativação preferencial do cromossomo $X$ normal, permanecendo o X mutado na maioria dos cromossomos X ativos. Esta forma de inativação não aleatória tem consequências negativas, podendo gerar algumas patologias (145).

Vários relatos de famílias com anormalidades na TBG confirmaram 0 padrão de herança ligado ao X $(85,117,146)$. Há apenas um relato na literatura de deficiência de TBG transmitida de forma autossômica dominante (118). Considerando o padrão de herança ligado ao $\mathrm{X}$, o defeito apresenta manifestação clínica plena em indivíduos hemizigotos (homens 46,XY ou mulheres $45, \mathrm{X0})(114)$. As mulheres heterozigotas geralmente apresentam 
níveis intermediários de TBG devido à compensação de dose pela inativação do cromossomo $X$. É sabido que mulheres $X X$ heterozigotas não manifestam a doença, mas a transmitem a seus filhos. Existe ainda uma outra possibilidade de uma mulher XX heterozigota manifestar a doença, que é por meio da inativação seletiva do cromossomo $X$ (124). Variações no modo como esse mecanismo se processa, seja por inativação aleatória ou seletiva, podem acarretar discrepâncias entre o genótipo e o fenótipo, e justificam a importância da avaliação do padrão de inativação do cromossomo $X$ nas mulheres afetadas $(124,147)$. 


\section{JUSTIFICATIVA}




\section{JUSTIFICATIVA}

Os primeiros registros sobre defeitos hereditários comprometendo, parcial ou totalmente, determinada etapa de síntese hormonal da tireoide foram publicados há cerca de 100 anos por Pendred e Osler (148). A partir da década de 1980, o rápido progresso da genética possibilitou avanços significativos na elucidação de alterações de mecanismos hormonais e genéticos em nível molecular. A deficiência parcial de TBG é a forma mais comum, ainda que pouco frequente, das anormalidades hereditárias que acometem a principal proteína de ligação aos hormônios tireoideanos no soro (54). A raridade desta situação clínica justifica um estudo de caracterização genética e molecular de uma família afetada podendo levar a uma melhor compreensão da fisiologia do transporte do hormônio tireoidiano e, sobretudo, evitar tratamentos desnecessários aos indivíduos acometidos.

O presente estudo buscou verificar a ocorrência de mutações no gene SERPINA7 em uma família brasileira com deficiência parcial de TBG, diagnosticada clinicamente. Esta família tem uma peculiaridade que chama a atenção: a manifestação da deficiência por uma das filhas, o que é extremamente raro, pois as mulheres em geral são apenas portadoras. Isto pode ocorrer pelo mecanismo de inativação do $X$, um mecanismo epigenético ainda pouco compreendido. Portanto, a identificação e caracterização de mutações nesta família pode ajudar a compreender este complexo mecanismo de silenciamento gênico. Além disso, também se buscou avaliar o padrão de inativação do cromossomo $\mathrm{X}$, para melhor elucidação do fenótipo clínico expresso pelo caso índice.

Adicionalmente, buscamos um melhor entendimento das relações de estrutura e função da proteína, o que vem a justificar o estudo de caracterização genética e molecular da família afetada pela deficiência, juntamente com análises estruturais e de modelagem. Com isso, espera-se contribuir para maior elucidação do papel do gene SERPINA7 na deficiência parcial de TBG, além de verificar a conservação/correlação dessa posição estrutural da proteína dentro das famílias das serpinas. 
OBJETIVOS 


\section{OBJETIVOS}

\subsection{Objetivos gerais}

Realizar investigação clínica, genética e molecular em uma família, cujo caso índice era uma mulher, com diagnóstico clínico de deficiência parcial da TBG (TBG-DP).

\subsection{Objetivos específicos}

1. Descrever e analisar o quadro clínico e laboratorial de uma família com deficiência parcial congênita da TBG (TBG-DP).

2. Realizar análise molecular do gene SERPINA7, que codifica a TBG, em uma família com deficiência parcial da TBG.

3. Caso seja identificada mutação potencialmente patogênica no gene SERPINA7, buscar-se-á:

3.1 Avaliar o padrão de inativação do cromossomo X com intuito de investigar mecanismos de silenciamento gênico que justifiquem o quadro clínico presente no caso índice (probanda).

3.2 Analisar o impacto funcional, in silico, da mutação no gene SERPINA7 identificada.

3.3 Realizar a análise estrutural e modelagem da possível mutação no gene SERPINA7, além de verificar a conservação/correlação dessa posição dentro das famílias das serpinas. 
MÉTODOS 


\subsection{MÉTODOS}

\subsection{SUJEITOS DO ESTUDO}

Este projeto foi aprovado sob o número CAAE 48417815.60000.0030, pelo Comitê de Ética da Faculdade de Ciências da Saúde, Universidade de Brasília (UnB) (ANEXO A - Parecer consubstanciado). Todos os sujeitos participaram da pesquisa mediante assinatura do Termo de Consentimento Livre e Esclarecido, pelo próprio paciente ou por seu responsável, no caso de menores de 18 anos (Apêndice A - Termo de consentimento livre e esclarecido).

O estudo foi realizado em 5 indivíduos de uma família brasileira. O caso índice é uma paciente de 37 anos do sexo feminino, que vinha anteriormente apresentando repetidamente testes da função tireoideana anormais, caracterizados por concentrações plasmáticas reduzidas de $T_{3}$ total $\left(T_{3}\right)$ e $T_{4}$ total $\left(\mathrm{TT}_{4}\right)$, e um nível de TSH normal enquanto utilizava levotiroxina 50 $\mathrm{mcg} / \mathrm{dia}$, durante vários anos.

O exame físico do caso índice não constava alterações, exceto para tireoide que apresentava um volume reduzido $\left(1 \mathrm{~cm}^{3}\right)$ na avaliação ecográfica. Após 6 semanas sem o uso da levotiroxina, testes adicionais da função tireoideana foram re-avaliados para determinação do nível plasmático TBG, que por fim confirmou o diagnóstico de deficiência de TBG (Figura 13). Além do caso índice, foram realizados exames laboratoriais nos outros membros da família (pai, irmã gêmea dizigótica e dois irmãos). Não foi realizada a análise da mãe do caso índice, já falecida no momento em que os dados foram avaliados. Foram coletadas, com o consentimento dos participantes, amostras de sangue para avaliação bioquímica e genética. 


\subsection{TESTES DA FUNÇÃO TIREOIDEANA}

Os pacientes em estudo foram avaliados clinicamente por médico endocrinologista, por meio de anamnese e exame físico, direcionado a patologias tireoideanas.

As dosagens plasmáticas de $\mathrm{T}_{3}$ total $\left(\mathrm{TT}_{3}\right), \mathrm{T} 4$ total $\left(\mathrm{TT}_{4}\right)$, $\mathrm{T} 4$ livre $\left(\mathrm{FT}_{4}\right)$, hormônio tireoestimulante (TSH), TBG e de anticorpos antitireoperoxidase (Anti-TPO) e anti-tireoglobulina (Anti-Tg) foram realizadas em laboratório comercial (Laboratório Sabin, Brasília-DF), utilizando o método de quimioluminescência.

Os valores de referência de normalidade para método (VR) foram:

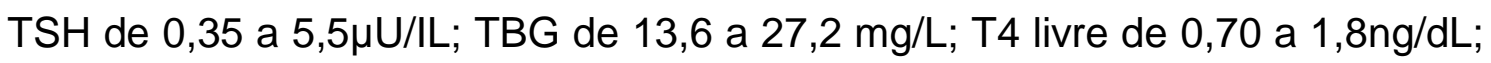

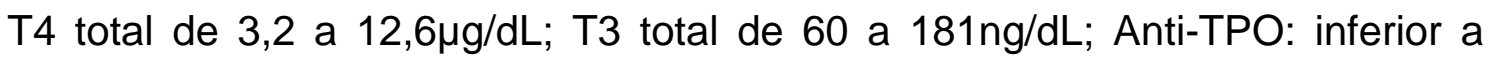
$35 \mathrm{U} / \mathrm{mL}$ e Anti-Tg: até $40 \mathrm{IU} / \mathrm{mL}$.

O teste de TRH também foi realizado no caso índice com o propósito de se avaliar a integridade do eixo hipotálamo-hipófise-tireoide. O teste do TRH (hormônio liberador da tireotropina) é um importante exame para se avaliar a integridade do eixo hipotálamo-hipófise-tireoide e em casos de suspeita de hipotireoidismo de causa central (tumores, pós cirurgia ou radioterapia, e outras causas de hipopituitarismo. Em casos de danos hipofisários a resposta é baixa, enquanto no dano hipotalâmico observa-se reposta normal ou exagerada. Consiste na administração de $200 \mu \mathrm{g}$ de TRH por via endovenosa e medida do TSH nos 15 minutos antes da administração, no momento da administração e 15, 30, 60 e 120 minutos após a injeção do TRH. O pico de TSH, que pode chegar a até 22 vezes a concentração sérica basal, ocorre aos 30 minutos em indivíduos eutireoideos. $O \mathrm{~T}_{3}$ e $\circ \mathrm{T}_{4}$ sérico se elevam, após 3 a 8 horas, respectivamente. A resposta do TSH ao estímulo com TRH ocorre entre 15 a 30 minutos, com um incremento mínimo de $5 \mu \mathrm{U} / \mathrm{mL}$ do valor basal. Adultos maiores de 40 anos de idade podem apresentar resposta normal com incremento de $2 \mu \mathrm{U} / \mathrm{mL}$. No hipotireoidismo primário a resposta do TSH é exagerada (> $35 \mu \mathrm{U} / \mathrm{mL}$ ). No hipotireoidismo secundário a resposta do TSH é insuficiente. No hipotireoidismo terciário a resposta é normal, mas atrasada (pico acima dos 60 minutos) (153). 


\subsection{ANÁLISE MOLECULAR}

4.3.1 Extração de DNA genômico de leucócitos do sangue periférico

O DNA genômico dos sujeitos do estudo foi extraído de leucócitos do sangue periférico pelo método de Salting-out modificado, descrito por Miller e colaboradores em 1988 (149).

O método consiste, primeiramente, em se obter o sangue periférico por meio de punção venosa de 12 a $16 \mathrm{~mL}$ de sangue em 4 tubos contendo 0 anticoagulante ácido etileno diaminotetracético (EDTA). Um dos tubos foi congelado a fim de manter material viável por mais tempo, caso fosse necessário realizar uma nova extração. O material dos outros três tubos foi transferido para um tubo falcon de $50 \mathrm{~mL}$ e acrescentado $30 \mathrm{~mL}$ de tampão de lise de hemácias (1mM NH4HCO3 + 1,4 mM NH4Cl). A solução foi homogeneizada e incubada durante 30 minutos em gelo e, posteriormente, 0 material foi centrifugado a $3000 \mathrm{rpm}, 4^{\circ} \mathrm{C}$, durante 15 minutos. $\mathrm{O}$ sobrenadante foi descartado e acrescentado mais tampão de lise, novamente incubado e centrifugado. Essa etapa foi repetida de três a cinco vezes até se obter um sedimento de leucócitos limpo (pellet) ao fundo do tubo cônico.

A esse pellet acrescentou-se $9 \mathrm{~mL}$ de TEN (TRIS 10mM ph8, EDTA 10mM ph8, NaCl2 150mM ph8), 180 $\mu \mathrm{L}$ de SDS10\% e $45 \mu \mathrm{L}$ de Proteinase $\mathrm{K}$. Em seguida, foi feita homogeneização com pipeta Pasteur de plástico, e incubou-se a $37^{\circ} \mathrm{C}$ por 12 horas (overnight) para se obter completa digestão protéica. Após a incubação foram acrescentados $3,6 \mathrm{~mL}$ de $\mathrm{NaCl}$ super saturado $(6 \mathrm{M})$, centrifugado a 3000rpm por 15 minutos em temperatura ambiente, e o sobrenadante foi transferido para outro tubo cônico. Ao sobrenadante foram acrescentados cerca de $20 \mathrm{~mL}$ de etanol absoluto gelado (JT Baker) para precipitar o DNA, e este foi retirado com auxílio de uma pinça ou bastão de vidro e transferido para um tubo de $1,5 \mathrm{~mL}$. E, finalmente, foram realizadas três lavagens com álcool 70\% (JT Baker) com intuito de remoção do excesso de sal por meio dessas sucessivas lavagens, e após a secagem, 0 DNA foi eluido em TE (TRIS $2 \mathrm{mM}$ ph8, EDTA 0,5 mM ph8). As amostras foram armazenadas $-4^{\circ} \mathrm{C}$ para posterior utilização. 


\subsubsection{Determinação da concentração do DNA}

Para avaliar a quantificação e pureza do DNA extraído foi utilizado o espectrofotômetro NanoVue Plus (GE Eletronics), que quantifica ácidos nucléicos a um comprimento de onda de 260nm. A pureza do DNA pode ser avaliada pela razão entre a quantificação a 260nm e 280nm (que corresponde à absorbância para proteínas). Todas as amostras utilizadas demonstraram

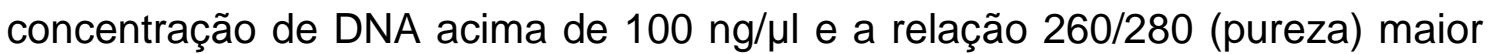
que 1,70 .

\subsubsection{Reação de polimerização em cadeia (PCR)}

A amplificação do DNA foi realizada por meio da técnica de PCR (Reação em Cadeia da Polimerase, polymerase chain reaction), que permite obter múltiplas cópias de uma região específica do DNA.

O DNA genômico foi utilizado como substrato para amplificação das regiões codantes do gene SERPINA7, gene que codifica a TBG, e que consiste de 5 éxons, sendo o primeiro não codante. Foi realizada reação de polimerização em cadeia (PCR) para amplificação dos éxons 1 ao 4 do gene SERPINA7, utilizando pares de oligonucleotídeos iniciadores (primers) desenhados especificamente para este estudo $(126,150,151)$. As sequências dos primers para cada éxon do gene SERPINA7 podem ser visualizadas na tabela de 4.

Tabela 4 - Oligonucleotídeos iniciadores utilizados para amplificação dos éxons 1 a 4 do gene SERPINA7.

\begin{tabular}{|c|c|c|c|c|}
\hline Primers & Sequências & LOCALIZAÇÃO* & $\mathrm{Ta}\left({ }^{\circ} \mathrm{c}\right)$ & Produto \\
\hline $1 \mathrm{~F}$ & 5'-GCTCAGGGAGTGTTTCATCCA-3' & 6591 a 6611 & 55 & 803pb \\
\hline $1 \mathrm{R}$ & 5'-GGGACACCTACTGATGCCAG-3' & 7374 a 7393 & 55 & \\
\hline $2 \mathrm{~F}$ & 5'-GCCTGATCCTCAGTCACTTGTAA-3' & 8192 a 8214 & 52 & $508 p b$ \\
\hline $2 \mathrm{R}$ & 5'-TCTGCCTCTGGGTTTCTGCT-3' & 8680 a 8699 & 52 & \\
\hline $3 F$ & 5'-TTGGCTGTACCTGAGTGCAT-3' & 9152 a 9171 & 52 & $550 \mathrm{pb}$ \\
\hline $3 R$ & 5'-TGGGACATAAAGGTCAAGGATGG-3' & 9679 a 9701 & 52 & \\
\hline $4 \mathrm{~F}$ & 5'-CCGTAGAATCGCCAGAGAATGA-3' & 9844 a 9866 & 52 & 532pb \\
\hline $4 \mathrm{R}$ & 5'-CAGCCAACAAAGTTCAGCCA-3' & 10357 a 10376 & 52 & \\
\hline
\end{tabular}


As reações de PCR para o gene SERPINA7 foram realizadas utilizando o kit GoTaq ${ }^{\circledR}$ Green Master Mix (Promega) de acordo com as orientações do fabricante. O protocolo geral para reação de PCR está descrito

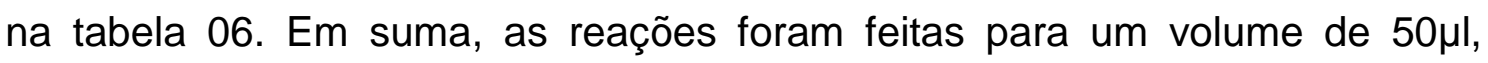
utilizando $20 \mu \mathrm{l} \mathrm{de} \mathrm{GoTaq}^{\mathrm{TM}}$ Green Master Mix (Promega®, Madison, WI, USA), $1 \mu \mathrm{l}$ de cada oligonucleotídeo iniciador (forward e reverse) e $1 \mu$ de DNA (tabela $5)$.

Tabela 5 - Quantitativo dos reagentes para realização da PCR para os éxons 1 ao 4 do gene SERPINA7.

\begin{tabular}{ll}
\hline Reagentes & Quantidades \\
DNA $100 \mathrm{ng} / \mu \mathrm{L}$ & $1 \mu \mathrm{L}$ \\
Primer F & $1 \mu \mathrm{L}$ \\
Primer R & $1 \mu \mathrm{L}$ \\
MIX GoTaq Green & $20 \mu \mathrm{L}$ \\
Água destilada & $17 \mu \mathrm{L}$ \\
& $50 \mu \mathrm{L}$ (volume final da reação) \\
\hline
\end{tabular}

A amplificação de todos os éxons foi otimizada utilizando-se um único protocolo de amplificação, conforme apresentado na tabela 6 .

Tabela 6 - Descrição das condições para realização da PCR para os éxons 1 ao 4 do gene SERPINA7.

\begin{tabular}{llll}
\hline Função & $\begin{array}{l}\text { Quantidade } \\
\text { (ciclos) }\end{array}$ & $\mathbf{T}^{\circ} \mathbf{C}$ & Tempo \\
\hline Desnaturação inicial & 1 & 95 & 3 minutos \\
Desnaturação & 35 & 95 & 30 segundos \\
Anelamento & 35 & 50 & 45 segundos \\
Extensão & 35 & 72 & 1 minuto \\
Extensão final & 1 & 72 & 10 minutos \\
\hline
\end{tabular}


Para avaliar a eficiência da amplificação, os produtos de PCR foram submetidos à eletroforese em gel de agarose a $2 \%$ em TAE, com brometo de etídeo a $10 \mathrm{mg} / \mathrm{mL}$; para comparação visual do padrão de migração dos produtos no gel, utilizou-se marcador de Peso molecular $1 \mathrm{~Kb}$ Plus 34 (Invitrogen ${ }^{\mathrm{TM}}$ ). O gel foi visualizado em luz ultravioleta e fotografado. Controles negativo e positivo foram utilizados em todas as reações.

\subsubsection{Sequenciamento genético automático}

Os produtos de PCR foram purificados pelo kit de purificação QIAquick $^{\mathrm{TM}}$ (Qiagen $^{\mathrm{TM}}$ ) e enviados para sequenciamento automático, nas orientações sense ( $\left.5^{\prime}>3^{\prime}\right)$ e antisense ( $3^{\prime}>5$ '). As reações de sequenciamento foram realizadas pela empresa especializada Macrogen Inc. (MACROGEN, Seoul, Coreia do Sul), que utiliza o aparelho ABI Prism ${ }^{\circledR} 3700$ Genetic Analyzer (Perkin-Elmer), a qual realiza sequenciamentos automáticos pelo método de Sanger.

\subsubsection{Leitura e análise das sequências}

As análises, alinhamentos e comparações entre as sequências foram realizadas com o auxílio de software especializado: Sequencher ${ }^{\circledR}$ versão 5.0.1. (Gene Codes Corporation versão Demo 4.10.1 2011, Ann Arbor, MI). As sequências obtidas, expressas em eletroferogramas, foram comparadas com a sequência referência disponível na base de dados PubMed (National Center for Biotechnology and Information - NCBI). Para o gene SERPINA7, gene que codifica a TBG: NCBI Reference Sequence NM_0211252.1e NM_000354.5.

\subsubsection{Análise preditiva in silico}

O software PolyPhen-2® (http://genetics.bwh.harvard.edu/pph2) foi utilizado para a predição in silico do efeito funcional da mutação encontrada. 


\subsection{AVALIAÇÃO DO PADRÃO DE INATIVAÇÃO DO CROMOSSOMO X}

O ensaio para avaliação do padrão de inativação do cromossomo $X$ foi feito com base na análise da metilação da repetição polimórfica $C A G$ do primeiro éxon do gene do receptor androgênico (AR, Androgen Receptor Gene, NCBI Reference Sequence NM_000044), localizado em Xq11.2, conforme descrito previamente por Allen e colaboradores com modificações (figura 10) (152).

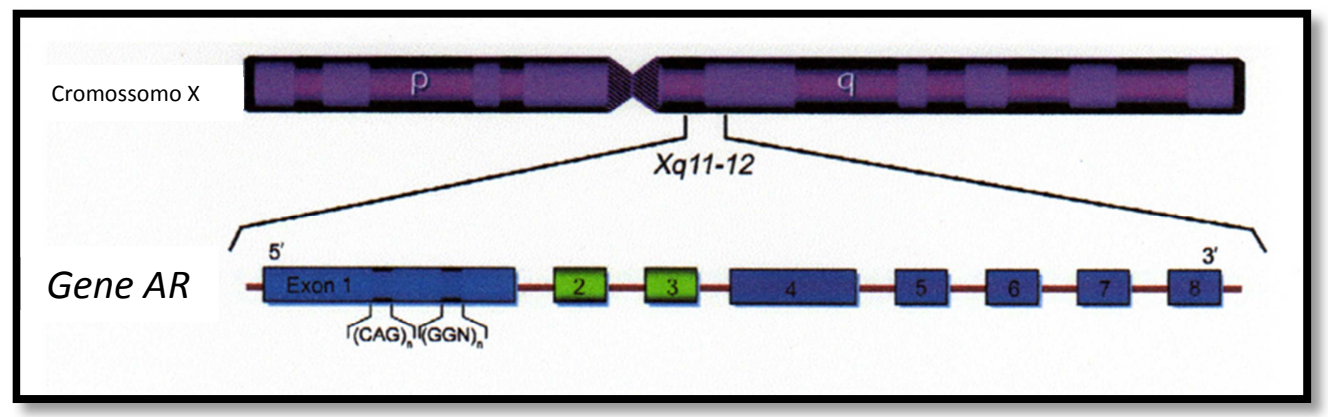

Figura 10 - Representação da localização do gene que codifica o receptor androgênico $(A R)$ no cromossomo X. A estrutura do gene do $A R$ está esquematizada na imagem inferior, em que os retângulos representam os éxons e as linhas entre eles representam os íntrons. $O$ éxon 1 inclui as regiões de repetições CAG e GGN. Fonte: Adaptado de Quigley CA, De Bellis A, Marschke KB, El-Awady MK, Wilson EM, French FS. Androgen receptor defects: historical, clinical, and molecular perspectives. Endocrine reviews. 1995 Jun;16(3):271-321.

\subsubsection{Digestão do DNA pela enzima Hhal}

O protocolo de digestão pela enzima Hhal consistiu em duas amostras de $1000 \mathrm{ng}$ de DNA foram preparadas simultaneamente: uma foi submetida à digestão pela enzima Hhal (Invitrogen, Carlsbad, USA), por 16 horas a $37^{\circ} \mathrm{C}$ no termociclador, deixando-se em seguida à temperatura de $65^{\circ} \mathrm{C}$ por 25 minutos para inativação da enzima; a outra amostra foi incubada, na ausência da enzima Hhal. Todas as reações foram preparadas com todos os reagentes participantes da digestão (água, tampão e BSA) e a amostra de DNA, para um volume final de $20 \mu \mathrm{L}$ (152). Assim, de forma resumida, uma amostra dos produtos de amplificação por PCR da sequência de repetição CAG no interior 
do gene de $A R$ foi submetida à digestão enzimática pela Hhal, enquanto a outra amostra permaneceu intacta (não digerido).

A enzima de restrição thal (Nova EnglandBioLabsInc $\left.{ }^{\circledR}, M A, E U A\right)$ é uma endonuclease que possui dois sítios de clivagem que se encontram próximos à repetição CAG (37bp e 78pb proximal). A enzima Hhal também é sensível à metilação, devido à presença de dinucleótidos $\mathrm{CpG}$ nos seus sítios de reconhecimento, e, portanto, apenas as regiões cromossômicas não metiladas (ativas) são clivadas (152). Consequentemente, a digestão pela enzima Hhal dos produtos de PCR permite uma determinação diferencial do estado de metilação da região no cromossomo $X$ que compreende as repetições CAG no gene de $A R$, a qual, por sua vez, está localizada próxima ao gene de interesse, SERPINA7.

4.4.2 Amplificação do produto da digestão e eletroforese em gel de agarose.

Para a amplificação por PCR da repetição CAG foram utilizados oligonucleotídeos iniciadores (primers) comerciais (Promega ${ }^{\circledR}$, Madison, WI, USA) representados na Tabela 7 , que também flanqueiam o sítio de restrição da enzima Hhal na sequência do gene $A R$. Como a enzima Hhal só corta os sítios de restrição desmetilados, ou seja, proveniente dos alelos do gene $A R$ localizados no cromossomo $X$ ativo, esses alelos não são amplificados. Assim, é possível determinar o padrão de inativação do cromossomo $\mathrm{X}$ analisando os alelos do cromossomo $\mathrm{X}$ inativo, isto é, aqueles que são amplificados após a digestão com a enzima Hhal (Figura 11).

Tabela 7- Oligonucleotídeos iniciadores utilizados para amplificação do éxon 1 do gene $A R$.

\begin{tabular}{|c|c|c|c|}
\hline Éxon & Nome & Primers & $\begin{array}{l}\text { Produto } \\
\text { (pb) }\end{array}$ \\
\hline 1 & AR1F & 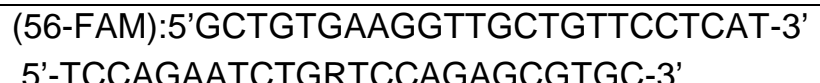 & $211-292$ \\
\hline
\end{tabular}


Após o passo de digestão enzimática, a região de repetição CAG do gene AR foi amplificada como se segue: 200ng de cada amostra de DNA molde (digeridas e não digeridas), equivalente a um volume de $4 \mu \mathrm{L}$, foram utilizados em um volume de reação final de $30 \mu \mathrm{L}$, no qual foram adicionados $30 \mathrm{mM}$ Tris ( $\mathrm{pH} 8,5), \mathrm{KCl} 10 \mathrm{mM}$, Hepes $10 \mathrm{mM}, \mathrm{MgCl}_{2} 1,5 \mathrm{mM}, 10 \mathrm{mM}$ de (NH4) $2 \mathrm{SO}_{4}, 200 \mu \mathrm{M}$ de cada dNTP, $15 \mathrm{pmol}$ de iniciadores forward e reverse e $1 \mathrm{U}$ de Taq DNA polimerase (Invitrogen, CA, EUA).

O programa de amplificação no termocliclador consistiu de um período de desnaturação inicial a $95^{\circ} \mathrm{C}$ durante $5 \mathrm{~min}$, seguido de 28 ciclos a $95^{\circ} \mathrm{C}$ durante $45 \mathrm{~s}, 60^{\circ} \mathrm{C}$ durante $30 \mathrm{~s}$ e $72^{\circ} \mathrm{C}$ durante $30 \mathrm{~s}$, e um passo final de extensão a $72^{\circ} \mathrm{C}$ durante 10 min (tabela 8 ).

Tabela 8 - Descrição das condições para realização da PCR para éxon 1 do gene $A R$.

\begin{tabular}{lll}
\hline Etapas do Ciclo & Temperatura & Tempo \\
\hline Desnaturação inicial & $95^{\circ} \mathrm{C}$ & 5 minutos \\
28 ciclos & & \\
- Desnaturação & $95^{\circ} \mathrm{C}$ & 45 segundos \\
-Anelamento dos primers & $60^{\circ} \mathrm{C}$ & 30 segundos \\
- Extensão & $72^{\circ} \mathrm{C}$ & 30 segundos \\
Extensão final & $72^{\circ} \mathrm{C}$ & 10 minutos \\
Finalização & $4^{0} \mathrm{C}$ & $\infty$ \\
\hline
\end{tabular}

Após a PCR, todas as amostras foram submetidas à técnica de eletroforese em gel de agarose 1,5X (figura 12). Para tanto, usou-se $6 \mu \mathrm{L}$ da amostra amplificada e $2 \mu \mathrm{L}$ de tampão de corrida. Em cada poço do gel foi pipetado $5 \mu \mathrm{L}$ da mistura. A eletroforese ocorreu em cuba horizontal, contendo TBE 1X e com os seguintes parâmetros: DDP de 100V e corrente de 40A por aproximadamente duas horas (Apêndice $B$ - eletroforese em gel de agarose). 
A

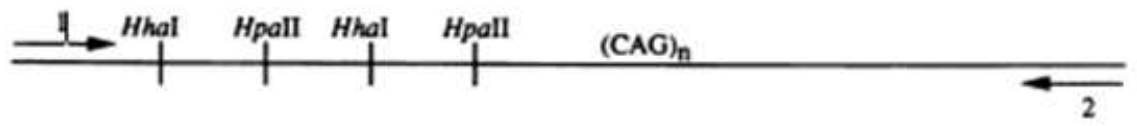

B Inativação aleatória do
cromossomo X paterno

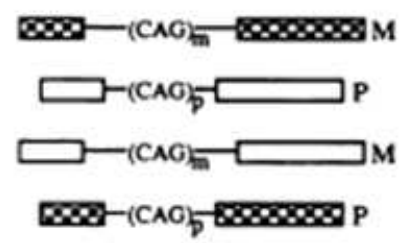

Inativação não-aleatória do cromossomo X paterno

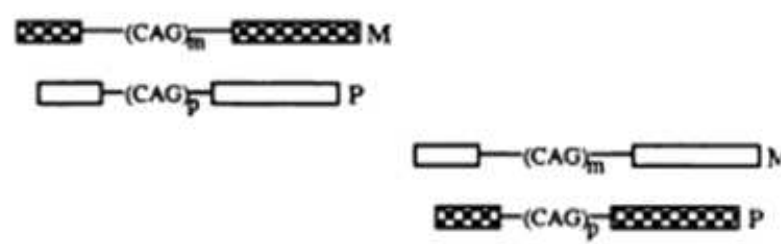

$000-(\mathrm{CAG})-0000000$ ?
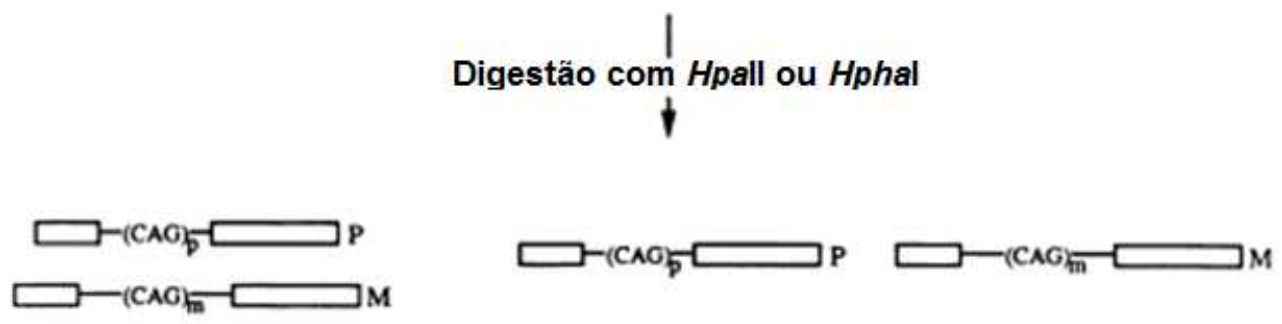

Amplificação por PCR

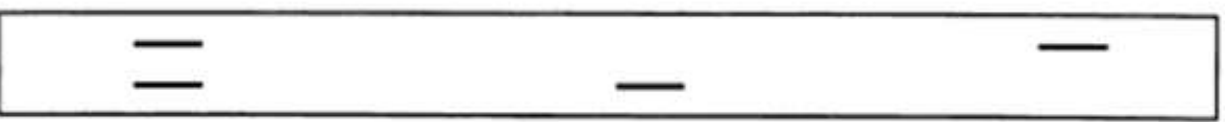

Eletroforese em gel de agarose

Figura 11 - A. Diagrama da região amplificada no primeiro éxon do gene do receptor de andrógeno humano $(A R)$. Dois sítios Hhal e dois Hpall estão localizados a aproximadamente $100 \mathrm{pb}$ em direção à extremidade 5' das repetições polimórficas CAG. A metilação desses sítios de restrição está relacionada com a inativação do cromossomo X. Os primers 1 e 2 foram desenhados para flanquear os sítios, sensíveis a metilação (cortados ou não por Hpall ou Hha/) e a repetição CAG, simultaneamente. B. Análise do padrão de inativação do cromossomo $X$ por PCR no primeiro éxon do gene do receptor androgênico humano. $O$ diagrama de fluxo ilustra os resultados esperados a partir do DNA isolado de populações de células, revelando padrões de inativação do $X$ tanto de forma aleatória (esquerda) ou não aleatória (direita). $\mathrm{M}$ e $\mathrm{P}=$ cromossomos $\mathrm{X}$ maternos e paternos, respectivamente; (CAG)m e $(C A G) P=$ Alelo associado à repetição polimórfica $C A G$ nos cromossomos $X$ maternos $e$ paternos, respectivamente. Após incubação com as enzimas sensíveis à metilação Hpal ou Hhal, os sítios no cromossomo $X$ ativo (xadrez) serão clivados, uma vez que são não metilados; os sítios do $X$ inativo não serão clivados, uma vez que são metilados. A amplificação por PCR da região delimitada pelos oligonucleotídeos iniciadores mostra o produto obtido do 
cromossomo $\mathrm{X}$ inativo clivado. Os alelos maternos e paternos são visualizados por eletroforese em gel de agarose. Fonte: Allen RC, Zoghbi HY, Moseley AB, Rosenblatt HM, Belmont JW 1992. Methylation of Hpall and Hhal sites near the polymorphic CAG repeat in the human androgen-receptor gene correlates with X chromosome inactivation. Am J Hum Genet 51: 12291239.

\subsubsection{Eletroforese Capilar.}

Os produtos de amplificação foram submetidos à análise por eletroforese capilar no sequenciador automático ABI-3130XL Applied Biosystems (Life Technologies) utilizando um marcador de peso molecular GS500 LIZ (Applied Biosystems, CA, EUA). Desta maneira, foi utilizado $1 \mu \mathrm{L}$ do material amplificado, $1 \mu \mathrm{L}$ de marcador de peso molecular e $9 \mu \mathrm{L}$ de formamida. A análise dos dados foi realizada utilizando-se o software Gene Mapper (Life Technologies). Todos os resultados nessa fase foram obtidos em parceria com o Laboratório de Genética da Faculdade de Medicina da Universidade de Brasília e com o Laboratório de Ciências Genômicas e Biotecnologia Molecular da Universidade Católica de Brasília - Campus Asa Norte.

\subsubsection{Cálculo da taxa de inativação.}

O cálculo da taxa de inativação foi feita com base na razão entre o valor pico de amplificação do menor alelo e a soma dos valores correspondentes aos dois alelos, com correção para o pico do mesmo alelo não digerido pela enzima, conforme descrito por Bittel e colaboradores (154). Nesta análise, a altura de cada pico é proporcional ao número de produtos de PCR de cada alelo de repetição CAG. $O$ razão de inativação do cromossomo $X$ representa a porcentagem de células em que cada alelo diferente é ativo (não metilado).

Índice de inativação:

(phd1/phu1)

(phd1/phu1)+(phd2/phu2) 
Onde:

phd1 = altura máxima do pico do primeiro alelo digerido

phd2 = altura máxima do pico do segundo alelo digerido

phu1 = altura máxima do pico do primeiro alelo não-digerido

phu2= altura máxima do pico do segundo alelo não-digerido

\subsection{ANÁLISE ESTRUTURAL COMPARATIVA À FAMÍLIA DE PROTEÍNAS SERPINAS E MODELAGEM MOLECULAR DA PROTEÍNA MUTANTE}

A fim de verificar padrões de conservação e de correlação para a posição 35, a família de proteínas serpinas foi analisada utilizando PFSTATS (155). Um alinhamento múltiplo de sequências contendo todas as serpinas no UniProt (Universal Protein Resource), um dos maiores bancos de dados que engloba dados de sequências de proteínas e dados de anotações, foi baixado a partir do banco de dados PFAM (156). O alinhamento completo, contendo 12260 sequências, foi filtrado a fim de remover os fragmentos e redundâncias (> 70\% de identidade), resultando em um alinhamento final de 2440 sequências. Assim, foram calculadas as frequências típicas do resíduo para posição 35 e também as possíveis correlações que envolvem tal posição. PFSTATS também foi usado para mapear posições equivalentes em todos os homólogos humanos.

O mutante encontrado na família com TBG-PD (R35W) foi modelado utilizando o protocolo descrito por Feyfant e colaboradores em 2007 (157), que consiste em otimização do gradiente conjugado seguido por uma curta dinâmica molecular como implementado no Modeller (158). Áreas de superfície acessíveis foram calculadas usando o programa Areaimol $(159,160)$ no pacote do CCP4 (161).

As análises estruturais e modelagem foram realizadas em colaboração com Prof. Lucas Bleicher da UFMG especificamente para esse estudo. 
RESULTADOS 


\subsection{RESULTADOS}

Em sua primeira avaliação, o caso índice (sujeito II-2) apresentou,

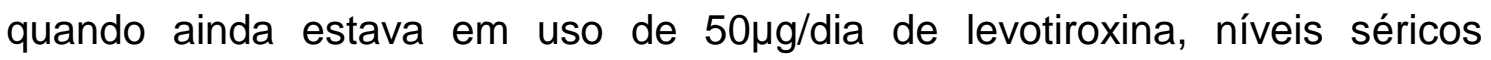
reduzidos de $\mathrm{TT}_{4}, \mathrm{TSH}$ e de TBG, além de valores normais de $\mathrm{TT}_{3}$ e $\mathrm{T}_{4}$ livre (Tabela 9). A presença de $\mathrm{TT}_{4}$ significativamente baixo, com $\mathrm{T}_{4}$ livre normal levaram a suspeita de deficiência de TBG, a qual foi confirmada com uma dosagem baixa de TBG no sangue. Entretanto, o reduzido nível de TSH encontrado foi questionável, mas que poderia ser devido ao uso prolongado de levotiroixina. Assim, optou-se por suspender a levotiroxina por no mínimo 6 semanas, para reavaliação da função tiroideana. Esse tempo é o necessário para que haja novo equilíbrio do eixo hipotálamo-hipofisário-tiroideano. Após suspensão do medicamento foi observado uma inesperada diminuição do nível de $\mathrm{T}_{4}$ livre, concordante com queixa de extrema fadiga da paciente, e um teste do TRH foi realizado e excluiu a existência de hipotireoidismo central (pico de TSH após estímulo com TRH $<25 \mu \mathrm{UI} / \mathrm{mL}$ - Apêndice F). A levotiroxina foi então reintroduzida $(50 \mathrm{mcg} / \mathrm{dia})$ e a paciente permaneceu eutireoidea após a introdução da medicação novamente.

Tabela 9 - Resultados dos exames laboratoriais do caso índice em uso de $50 \mu \mathrm{g} /$ dia de levotiroxina e após sua retirada

\begin{tabular}{cccccc}
\hline & TSH & $\mathrm{TT}_{4}$ & $\mathbf{F T}_{4}$ & $\mathrm{TT}_{3}$ & TBG \\
\hline $\begin{array}{c}\text { Em uso da } \\
\text { levotiroxina } \\
\begin{array}{c}\text { Após a } \\
\text { retirada da }\end{array}\end{array}$ & $0,02 \mathrm{uUl} / \mathrm{mL}$ & $1,9 \mu \mathrm{g} / \mathrm{dL}$ & $0,7 \mathrm{ng} / \mathrm{dL}$ & $67,35 \mathrm{ng} / \mathrm{dL}$ & $5,9 \mathrm{mg} / \mathrm{L}$ \\
$\begin{array}{c}\text { levotiroxina } \\
\begin{array}{c}\text { Valor de } \\
\text { Referência }\end{array}\end{array}$ & $0,39 \mathrm{uUl} / \mathrm{mL}$ & $2,4 \mu \mathrm{g} / \mathrm{dL}$ & $0,6 \mathrm{ng} / \mathrm{dL}$ & $35,09 \mathrm{ng} / \mathrm{dL}$ & $5,5 \mathrm{mg} / \mathrm{L}$ \\
& $\mathrm{uUl} / \mathrm{mL}$ & $\begin{array}{c}3,2-12,6 \\
\mu \mathrm{g} / \mathrm{dL}\end{array}$ & $\begin{array}{c}0,7- \\
1,8 \mathrm{ng} / \mathrm{dL}\end{array}$ & $\begin{array}{c}60- \\
181 \mathrm{ng} / \mathrm{dL}\end{array}$ & $\begin{array}{c}13,6-27,2 \\
\mathrm{mg} / \mathrm{L}\end{array}$ \\
\hline
\end{tabular}

Os dois irmãos do caso índice (II-1 e II-4) eram assintomáticos e também apresentaram níveis séricos baixos de TBG (3,5mg/L), além de valores reduzidos de $\mathrm{TT}_{3}$ e $\mathrm{TT}_{4}$, compatíveis clinicamente com deficiência parcial de TBG (TBG-PD). Os testes laboratoriais da irmã gêmea dizigótica do caso índice (II-3) e do pai do caso índice (I-1) foram normais. Os resultados bioquímicos e a genotipagem estão esquematizados na figura 12 . 
A

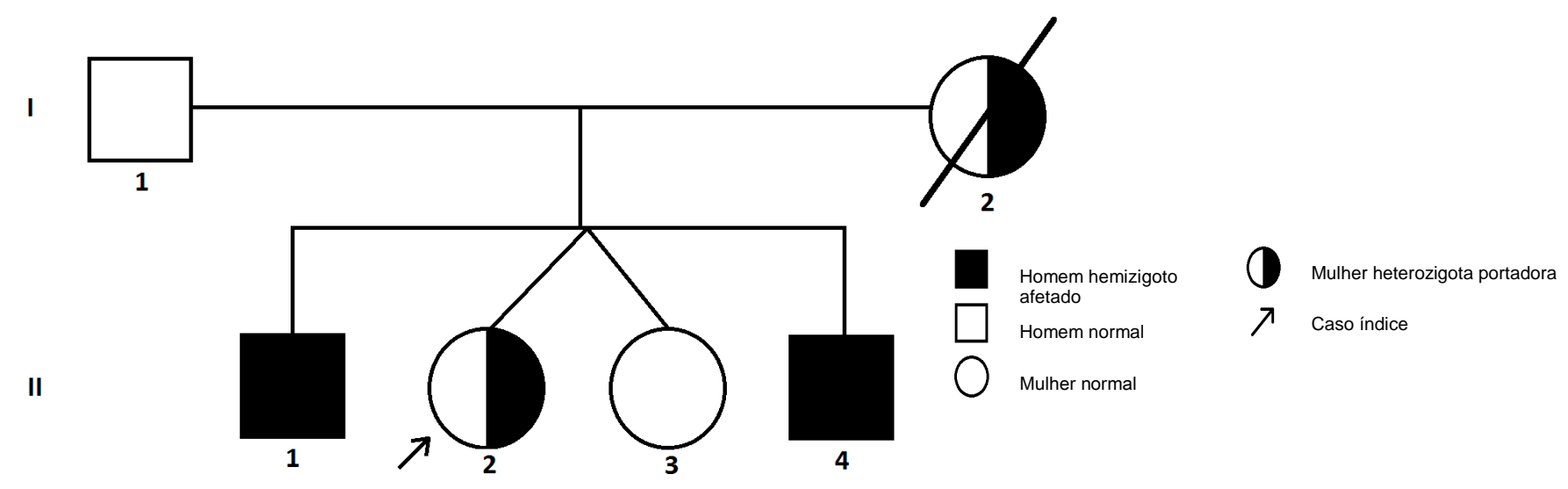

B

\begin{tabular}{|c|c|c|c|c|c|c|c|}
\hline & $\mid-1$ & II-1 & II-2 & II-3 & II-4 & $\mid-2$ & $\begin{array}{c}\text { Valor de } \\
\text { Referência }\end{array}$ \\
\hline Idade & 75 & 35 & 37 & 37 & 42 & ND & \\
\hline $\mathrm{TT}_{4}$ & ND & 1,9 & 2,4 & 7,4 & 2,1 & ND & $3,2-12,6 \mu \mathrm{g} / \mathrm{dL}$ \\
\hline $\mathrm{TT}_{3}$ & ND & 46,65 & 35,09 & 86,69 & 45,5 & ND & $60-181 \mathrm{ng} / \mathrm{dL}$ \\
\hline $\mathrm{T}_{4}$ livre & 1,2 & 1,4 & 0,6 & 0,8 & 1,51 & ND & $0,7-1,8 \mathrm{ng} / \mathrm{dL}$ \\
\hline TSH & 2,83 & 1,71 & 5,39 & 1,35 & 3,65 & ND & $\begin{array}{c}0,35-5,5 \\
\mathrm{uUI} / \mathrm{mL}\end{array}$ \\
\hline TBG & 23,4 & 3,5 & 5,5 & 18,5 & 3,5 & ND & $13,6-27,2 \mathrm{mg} / \mathrm{L}$ \\
\hline $\begin{array}{c}\text { Ac } \\
\text { TPO/Tg }\end{array}$ & ND & ND & $-/-$ & ND & ND & ND & $-/-$ \\
\hline
\end{tabular}

Figura 12 - Heredograma da família estudada e resultados dos exames laboratoriais da função tireoideana de três irmãos afetados pela deficiência parcial de TBG (TBG-PD) devido à mutação no gene p.R35W SERPINA7. A. Heredograma da família mostrando um padrão de herança recessivo ligada ao X, onde o caso índice (II-2) foi heterozigota e seus dois irmãos (II 1 e II- 4) foram hemizigotos para a mutação. A mãe (I- 2) já falecida, não há dados disponíveis, era supostamente uma portadora obrigatória da mutação p.R35W. B. Testes das funções da tireoide compatíveis com TBG-PD nos três irmãos afetados (resultados anormais são mostrados em negrito). ${ }^{*}$ os testes da função tiroideana foram obtidos depois da suspensão de 6 semanas da levotiroxina. $\mathrm{TT}_{4}: \mathrm{T}_{4}$ Total; $\mathrm{TT}_{3}: \mathrm{T}_{3}$ Total; $\mathrm{FT}_{4}: \mathrm{T}_{4}$ livre; ND: Não determinado; $\mathrm{TSH}$ : hormônio tireotrófico; TBG: globulina ligadora de tiroxina. 
A mãe do caso índice já era falecida e não existem dados clínicos disponíveis. No entanto, três tias maternas foram examinadas e duas delas tiveram testes positivos para anticorpos da tireoide, apesar de terem a função tireoidiana normal. Uma das duas últimas também apresentou um baixo nível de TBG (10,8mg/L - intervalo:13,0-39,0), embora os testes genéticos confirmatórios não tenham sido realizados (Apêndice D).

O sequenciamento do gene SERPINA7 evidenciou uma nova mutação missense nos indivíduos com os testes da função tireoideana compatíveis com TBG-PD (II-1, II-2, e II-4) (Apêndice C - Imagens dos resultados dos sequenciamentos). A mutação consistiu em uma substituição de uma citosina por uma timina na posição do nucleotídeo 163 do éxon 1 do gene SERPINA7, acarretando alteração do códon 35 de CGG para TGG, que resultou na tradução de um triptofano ao invés de uma arginina no códon 35 (p.R35W) da proteína madura. A mutação se apresentou em hemizigose nos dois indivíduos afetados do sexo masculino (sujeitos II-1 e II-4) e em heterozigose na mulher (caso índice, II-2) (Figura 13). Apesar de não se dispor dos dados clínicos e genéticos da mãe do caso índice, a análise do clássico padrão de herança ligado ao $X$ nesta família estudada permite predizer que a mãe era heterozigota para a mutação encontrada. A predição in silico do efeito funcional da mutação p.R35W indicou que esta variação é possivelmente danosa, com um escore de $79,5 \%$ (sensibilidade: $84 \%$, especificidade: $93 \%$ ). Para essa análise foi utilizado o códon 55, pois o software requer toda a sequência da referência codificada pelo gene SERPINA7 (Apêndice E), incluindo a sequência do peptídeo sinal. Para fins de definição e nomenclatura oficial da mutação, a contagem de aminoácidos não incluiu o peptídeo sinal, portanto, a mutação está localizada no códon 35 da proteína madura, após clivagem do peptídeo sinal. Tal nomenclatura está de acordo com as mutações previamente descritas no gene SERPINA7 (29). 
A

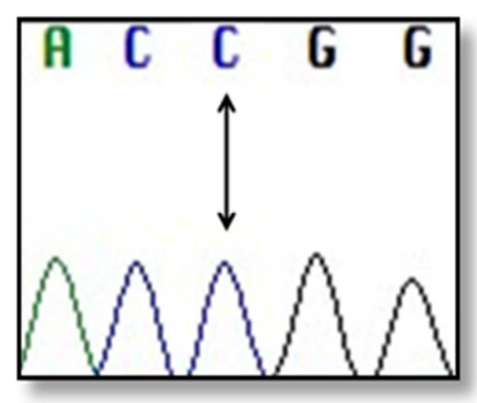

SELVAGEM

I-1 e II-3
B

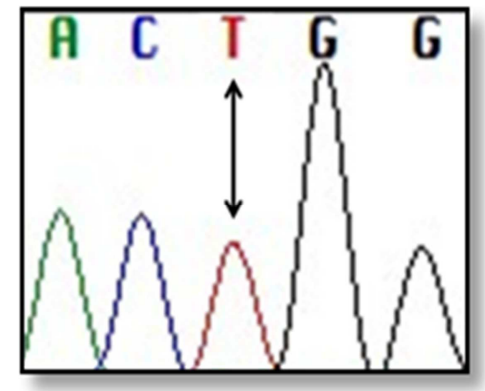

MUTAÇÃO NO DNA

p.R35W EM

HEMIZIGOSE

II-1 e II-4
C

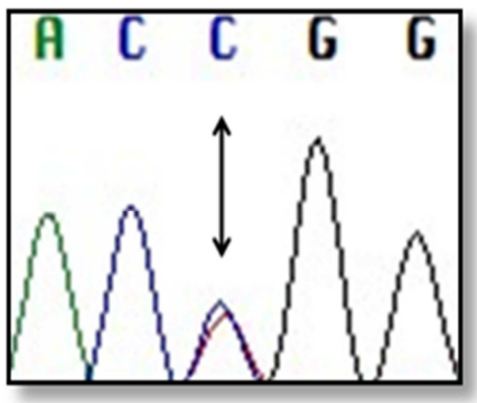

MUTAÇÃO NO DNA

p.R35W EM

HETEROZIGOSE

II-2

Figura 13 - Eletroferogramas do sequenciamento de parte do éxon 1 do gene SERPINA7, mostrando a substituição de uma citosina $(\mathrm{C})$ por uma timina $(\mathrm{T})$ na posição correspondente ao códon 35 da proteína madura (mutação p.R35W). A) Sequência encontrada nos indivíduos não afectados (I-1 e II-3); B) Sequência encontrada nos probandos irmãos (II - 1 e II - 4), mostrando a mutação em hemizigose; C) Sequência do caso índice, mostrando heterozigosidade para a mutação p.R35W.

A análise do padrão de inativação do cromossomo $X$ realizada para 0 caso índice mostrou uma razão de inativação de 20:80, sendo o primeiro valor representando a proporção de células que carrega o alelo menor não metilado (ativo) para repetição polimórfica CAG presente no sítio de restrinção do gene $A R$, e o segundo, a proporção para o alelo maior. Foram observados picos de amplificação para os dois alelos antes e após a digestão enzimática (Figura 14). 
Antes da digestão com Hhal

A

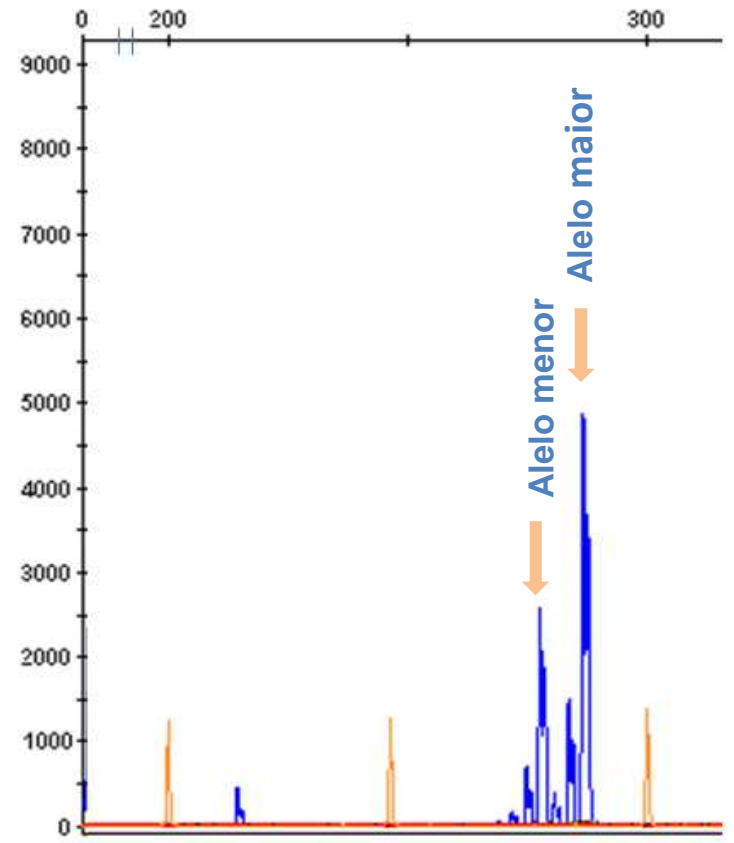

Após digestão com Hhal

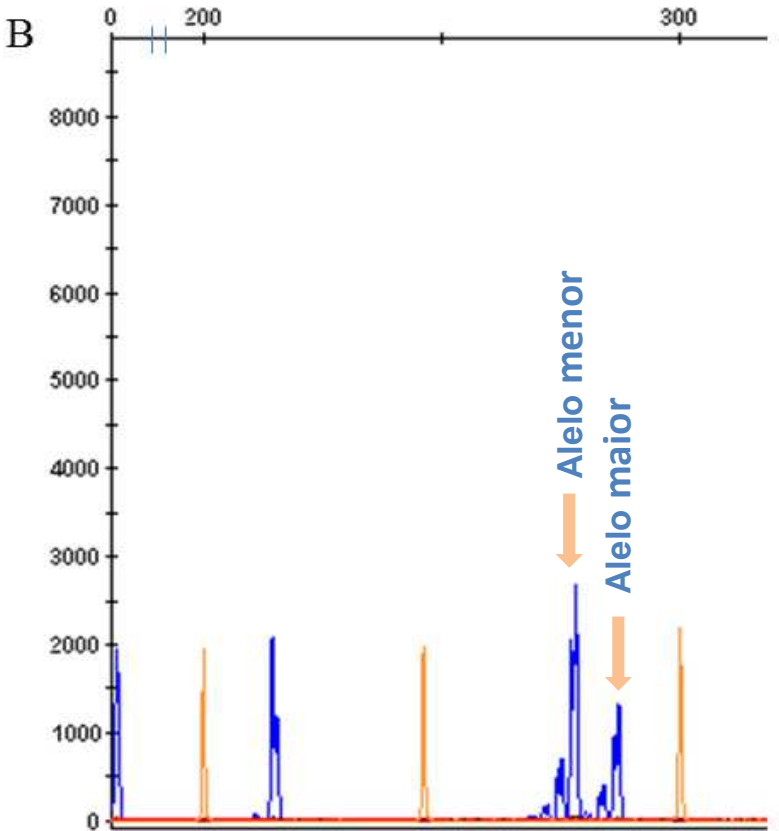

Figura 14 - Análise do padrão de inativação do cromossomo $X$ docaso índice com a deficiência parcial de TBG (caso índice). Os picos de amplificação para o menor e maior alelo com repetições CAG do gene do receptor de andrógeno, antes $(A)$ e após $(B)$ o tratamento com a lenzima Hhal são mostrados. $O$ eixo $Y$ mostra os valores dos picos de amplificações, os quais são proporcionais ao número de produtos de PCR para cada alelo. Os valores de amplificação para o alelo menor (278bp), digerido e não digerido, foram de 1868 e 2681, respectivamente. Para o alelo maior (287bp), não digerido e digerido, os valores de amplificação foram de 1335 3674 e 1335, respectivamente. O cálculo da razão de inativação do cromossomo $X$ foi de 20:80 baseado no método descrito anteriormente por Bittel e colaboradores (154), onde o primeiro alelo é o menor.

$\mathrm{Na}$ análise da estrutura, o carbono alfa do resíduo 35 encontra-se a cerca de $17 \AA ̊$ de distância do átomo mais próximo do $T_{4}$ na estrutura intacta da TBG (código PDB: 4X30). Este resíduo reside numa hélice, com a sua cadeia lateral localizada de frente para o solvente (modelo mostrado na Figura 15 A). Ao analisar os padrões de conservação e de correlação envolvendo este resíduo, pode ser visto que os resíduos mais frequentes nestas posições são as lisinas (26,7\%), argininas (18,4\%) e glutaminas (10,8\%). Triptofanos, tal qual verificado na mutação descrita nessa família, são extremamente raros $(0,1 \%)$ e não há significantes $\left(p<10^{-10}\right)$ correlações de emparelhamentos envolvendo resíduos nesta posição. 
Embora esta posição esteja na superfície da proteína e seja dominada pelos resíduos polares, eles não são apenas os que interagem completamente com o solvente. Na verdade, a área total de superfície acessível na arginina 35 na TBG nativa é $57 \AA^{2}$, menos do que $25 \%$ da área exposta de uma arginina em um tripéptido GRG. A razão para tal comportamento é o fato de que, em vez de interagir apenas as com águas dos solventes, a Arg35 está também envolvida com interações eletrostáticas com os principais oxigênios das cadeias da Met264 (metionina 264) e Asp261 (aspártico 261), e também do oxigênio do grupo carboxamida na Asn32 (asparagina 32), e ainda com duas moléculas de água, como pode ser visto na Figura $15 \mathrm{~B}$.
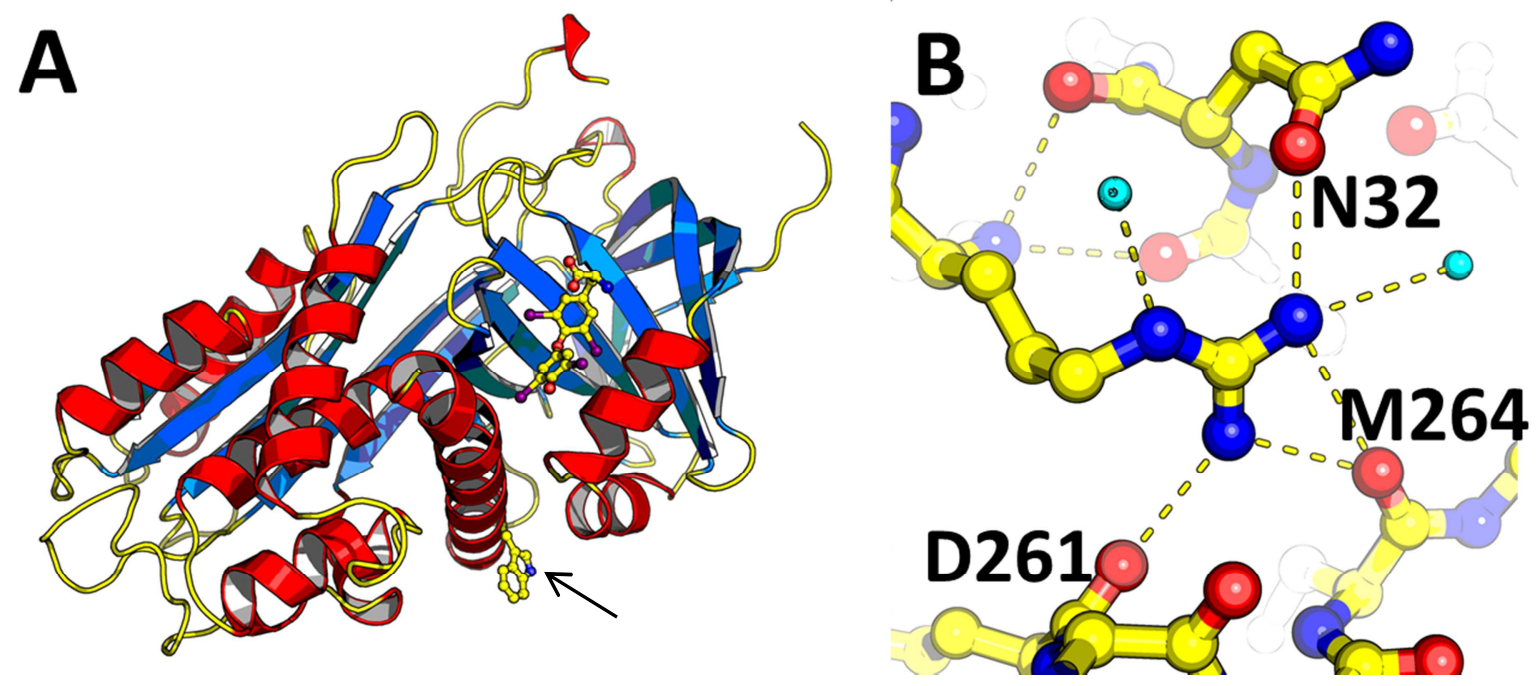

Figura 15 - Estrutura da TBG mostrando a localização do mutante R35W e suas interações. A. Estrutura cristalográfica da TBG mostrando a localização do mutante, $\mathrm{R} 35 \mathrm{~W}$, em relação ao sítio de ligação ao $\mathrm{T}_{4}$. O resíduo 35 (marcado em amarelo) encontra-se na primeira hélice $-\mathrm{hA}$ - (em vermelho) e sua cadeia lateral fica de frente para o solvente. Encontra-se a uma distância de $17 \AA ̊$ do átomo mais próximo do $T_{4}$ na estrutura intacta da TBG. B. Detalhe da região onde ocorre a mutação mostrando os resíduos (N32, M264, D261) que interagem diretamente com a Arg35 e com duas moléculas de água.

$\mathrm{Na}$ análise para os homólogos da família das serpinas em seres humanos foi visto que esta posição também é dominada por lisinas, argininas e glutaminas e também por outros resíduos polares (histidinas e asparaginas também são comuns), mas nunca são observados triptofanos. 
DISCUSSÃO 


\subsection{DISCUSSÃO}

A TBG é uma glicoproteína sintetizada pelos hepatócitos, sendo a principal responsável pelo transporte sérico dos hormônios tireoideanos, apresentando uma alta afinidade ao T4 (75\% da ligação do T4 sérico) (29). Variações na concentração da TBG, por conseguinte, alteram os níveis sanguíneos de T4 e T3, contudo não afetam a função tireoideana, desde que as frações livres permaneçam normais. A deficiência de TBG é uma condição benigna que não causa nenhum distúrbio metabólico e, consequentemente, não implica em alterações na função tireoideana nos indivíduos afetados (32). Porém, deve ser reconhecida para se evitar erros no diagnóstico de disfunção tireoidiana. Assim, seu conhecimento e definição tem importancia prática significativa, pois alterações na quantidade da TBG podem ser erroneamente interpretadas e levar a tratamentos desnecessários.

Anormalidades na TBG levam a três diferentes fenótipos de acordo com a concentração sérica presente de TBG, que são classificadas em deficiência completa, parcial ou em excesso. Nos casos de TBG-CD, a concentração sérica é indetectável, já na TBG-DP há uma redução dos níveis nos homens afetados $(32,123)$. Neste estudo foi relatado uma família na qual uma mulher (caso índice) e seus dois irmãos tinham TBG-PD devido a uma nova mutação missense no gene SERPINA7, p.R35W. Interessantemente, o caso índice apresentou um histórico de baixos níveis de $\mathrm{TT}_{4}$ repetidamente, durante $\mathrm{O}$ tratamento com hormônio da tireoide por muitos anos devido a um diagnóstico presuntivo de hipotireoidismo. Depois de retirada levotiroxina $\left(L-T_{4}\right)$, foi observado um nível $\mathrm{T}_{4}$ livre inesperadamente baixo, o que não poderia ser atribuído à deficiência de TBG por si só, já que a deficiência de TBG não influencia significativamente a fração livre da tiroxina. Sendo assim, foi descartada a hipótese de hipotireoidismo central e considerou-se a existência de uma sobreposição adicional de uma disfunção tireoidiana, ou até mesmo a possibilidade de achado ocasional em testes laboratoriais, o que é menos provável, considerando a repetição dos resultados dos testes. Embora os anticorpos tireoideanos fossem indetectáveis, é de salientar que a paciente tinha história familiar de autoimunidade na tireoide (duas tias maternas) e apresentava-se com um volume muito pequeno da glândula tireoide, observado 
em ultrassonografia, apoiando a coexistência de uma disfunção tiroideana sobreposta. Igualmente, Domingues e colaboradores (162) relataram uma família em que a deficiência de TBG foi associada a níveis reduzidos de $T_{4}$ livre concomitantemente com bócio e nódulos em parentes afetados. No geral, estes casos ilustram o quão desafiador é a interpretação dos testes da função tireoideana no contexto onde há defeitos simultâneos da tireoide.

Desde 1966, pesquisadores mostram que o padrão de herança na TBGCD seguia o padrão ligado ao X. Da mesma forma, um pouco mais tarde, também foi sugerido esse mesmo padrão de herança na TBG-DP, exceto para um único caso relatado na literatura de deficiência de TBG transmitida de forma autossômica dominante (118). Assim, considerando que o padrão de herança ligada ao X é típico na deficiência de TBG, a expressão fenotípica completa em mulheres heterozigotas com mutações no gene SERPINA7 é rara, devido à compensação por dosagem, isto é, pela expressão do gene ser resultante da inativação aleatória de um dos seus dois cromossomos $\mathrm{X}$, permanecendo, assim, a expressão do alelo normal na maioria dos casos $(29,32,114,142)$. Por esta razão, heterozigotas geralmente têm níveis séricos TBG intermediários entre indivíduos normais e homens hemizigóticos com deficiência de TBG (32). No entanto, as mulheres heterozigotas podem eventualmente apresentar uma expressão fenotípica semelhante aos homens hemizigóticos, que geralmente é devido a desvios no padrão de inativação do cromossomo $X$, ou seja, a inativação seletiva. A expressão completa da deficiência de TBG também foi descrita em mulheres com síndrome de Turner e um cariótipo 45, X (114).

No presente estudo, as concentrações plasmáticas de TBG do caso índice (5,5mg/dL; faixa normal: $13,6-27,2 \mathrm{mg} / \mathrm{dL}$ ) foram abaixo do esperado para uma mulher com TBG-PD em heterozigose, que é, em média, da metade superior da concentração normal.

Fingerhut e colaboradores (163) relataram um caso de uma paciente heterozigota para uma mutação causadora de TBG-PD (TBG-Allentown) que tinha níveis de TBG no limite inferior da normalidade. Okamoto e colaboradores (124) também relataram uma mulher heterozigota para mutação TBG-PD-J com um nível TBG de $2 \mathrm{mg} / \mathrm{L}$, mais baixo do que o valor observado nos indivíduos do sexo masculino desse estudo. Embora haja variações na sensibilidade e precisão dos ensaios para mensurar a TBG e esses podem ser 
responsáveis por algumas discrepâncias nos resultados, estes casos ilustram a variabilidade genótipo-fenótipo presente em mulheres heterozigotas portadoras de mutações no gene SERPINA7, o que é frequentemente relacionado com as variações no padrão de inativação do cromossomo X (146). Há relato de mulheres heterozigotas para as mutações TBG-CD-J e TBG-PD-J que apresentaram o mesmo fenótipo que indivíduos hemizigotos em decorrência da inativação seletiva do cromossomo X (124).

$O$ processo de inativação aleatória do cromossomo $X$ no sexo feminino ocorre bem precocemente logo nos primeiros estágios do desenvolvimento embrionário quando o embrião contém aproximadamente 5.000 células. Nesse processo, muitos genes de um dos dois cromossomos $X$ em mulheres são epigeneticamente silenciados e falham em produzir qualquer produto. Dessa forma, apenas uma cópia do cromossomo $X$ encontra-se completamente ativa em indivíduos de ambos os sexos, igualando a expressão aos genes ligados ao $X$ nos dois sexos $(144,154)$. A exceção é o que se observa em mamíferos marsupiais, nos quais as fêmeas de cangurus apresentam, preferencialmente, inativação do cromossomo $X$ de origem paterna (164). Na população feminina em geral, a inativação do cromossomo $X$ acontece normalmente de maneira aleatória com uma proporção média de 50:50 na proporção de células possuindo tanto o alelo paterno $(\mathrm{Xp})$ ou materno (Xm) ativo (não metilado), sendo mantido em cada linhagem clonada $(144,154)$. Em alguns casos que envolvam alterações estruturais ou de sequência do cromossomo $X$ foi visto que a inativação pode ocorrer de forma não aleatória, ocorrendo uma inativação preferencial do cromossomo alterado, proporcionando ao organismo uma seleção dirigida para preservar as funções celulares com a manutenção ativa do cromossomo $X$ não afetado $(165,166)$.

$A$ inativação aleatória do cromossomo $X$ é controlada pelo centro de inativação do cromossomo $X(C I X)$ e pelo gene XIST (transcrito específico para inativação do $X)$, que inicia a inativação e a propagação do estado inativado. $O$ cromossomo $X$ inativo é lentamente replicado, e migra para a região perinuclear, a qual é rica em enzimas importantes na produção da estrutura inativa do cromossomo. A partir da escolha de qual cromossomo $X$ deverá ser inativado, é iniciado o comando para o centro de inativação do cromossomo $X$, e o gene XIST, então, passa a produzir transcritos não codantes que se 
posicionam ao longo do próprio cromossomo. Essa fase dará início às outras manifestações celulares epigenéticas necessárias para que a inativação ocorra, tais como, modificações de histonas, incorporação de diferentes tipos de histonas ao cromossomo a ser inativado, a metilação do DNA, além da compartimentalização do cromossomo (167).

A média da razão de inativação segue uma distribuição Gaussiana, em que os padrões altamente desviados representam eventos incomuns. O padrão de inativação do cromossomo $X$ é classificado como aleatório quando há a relação $\leq 80 \%$ de um dos alelos do cromossomo $X$ e de $20 \%$ do segundo alelo; perfil moderadamente desviado se a proporção for entre 80:20 e 90:10, e altamente desviado para perfis >90:10 $(144,165)$. Cerca de $8 \%$ das mulheres apresentam um desvio de inativação (>80:20 ou <20:80) e apenas $1 \%$ apresentam desvios extremos de padrão de inativação (>95:5 ou $<5: 95)$ $(144,154)$.

A investigação do padrão de inativação do cromossomo $X$ no caso índice foi feita pelo método de análise do padrão de metilação do gene $A R$, que foi escolhido devido a sua localização (Xq11.2) ser próxima ao gene TBG (Xq22.2), diminuindo, assim, a possibilidade de quebra do linkage entre os dois genes $(124,154,144)$.

Um achado interessante neste estudo foi que a tia materna do caso índice tinha um nível de TBG de 10mg/L (intervalo normal: 13,7-27mg/L), o que é consistente com a TBG-DP e é típico de mulheres heterozigotas afetadas. Este achado contrasta com o nível de TBG mais baixo encontrado no caso índice, apesar de que ambos os testes laboratoriais serem realizados pelo mesmo processo de ensaio. Porém, não foi possível realizar os testes genéticos na tia do caso índice, o que poderia ter contribuído para melhor demonstrar diferentes padrões de inativação do cromossomo $X$ entre as mulheres afetadas até mesmo na mesma família.

Até o momento da conclusão deste estudo, de acordo com Pappa e colaboradores, em torno de 57 mutações no gene SERPINA7 foram identificadas, sendo 49 mutações (incluindo a descrita nesse estudo) geneticamente caracterizadas (tabela 10), sendo relatados nos bancos de dados genéticos públicos (NCBI e 1000genomes). Tais mutações incluem 11 deleções, 7 em sítios de splicing, 4 nonsense e 22 mutações missense, sendo 
27 encontrada na deficiência completa e 18 deficiência parcial de TBG. Dentre as mutações descritas, 7 ocorrem em associação a um polimorfismo conhecido do gene (p.L283F), que é frequentemente encontrado na população normal e não causa alterações estruturais na molécula da TBG (125). Duas outras variantes da TBG, slow (TBG-S) e chicago (TBG -CH ou TBG-Cgo) são encontradas, uma na TBG-DP e a seguinte provoca alteração qualitativa, respectivamente (29).

Tabela 10 - Mutações no gene SERPINA7 já descritas, incluindo a do presente estudo, e que resultam em deficiência completa ou parcial de TBG

\begin{tabular}{|c|c|c|c|c|}
\hline $\begin{array}{c}\text { Tipo e nome da } \\
\text { mutação }\end{array}$ & $\begin{array}{l}\text { Abreviação } \\
\text { da mutação }\end{array}$ & Identificação & Efeito & Referência \\
\hline \multicolumn{5}{|l|}{ Mutações de Sítio de } \\
\hline \multicolumn{5}{|l|}{ Splicing } \\
\hline Milano $(*)$ & CDMi & g.IVS1,+2_3insT & TBG-CD & 168 \\
\hline Kantakee & CDK & g.IVS2,-2A>G & TBG-CD & 169 \\
\hline Jackson & CDJa & g.IVS4,+5G>A & TBG-CD & 126 \\
\hline Andrews & CDAN & g.IVS1 + 2T>C & TBG-CD & 170 \\
\hline Berlin & CDBn & g.IVS3, del & TBG-CD & 170 \\
\hline Houston & $\mathrm{CDH}$ & g.IVS3,G>A & TBG-CD & 29 \\
\hline Lisle & CDL & g.IVS4, T>A & TBG-CD & 29 \\
\hline \multicolumn{5}{|l|}{ Mutações nonsense } \\
\hline Portuguese 1 & CDP1 & p.S23X & TBG-CD & 171 \\
\hline Portuguese 2 & CDP2 & p.Q223X & TBG-CD & 171 \\
\hline Buffalo $(*)$ & $\mathrm{CDB}$ & $\begin{array}{l}\text { p.W280X } \\
\text { (TGG>TAG) }\end{array}$ & TBG-CD & 150 \\
\hline Taiwanese 2 & CDT2 & $\begin{array}{c}\text { p.W280X } \\
(\mathrm{TGG}>\mathrm{TGA})\end{array}$ & TBG-CD & 172 \\
\hline \multicolumn{5}{|l|}{ Mutações missense } \\
\hline Allentown & PDAT & p.H-2Y & TBG-PD & 163 \\
\hline San Diego $(*)$ & PDSD & p.S23T & TBG-PD & 173 \\
\hline Brasilia & PDB & p.R35W & TBG-PD & \\
\hline Wanne-Eickel & PDWE & p.R35E & TBG-PD & 29 \\
\hline Taiwanese $1(*)$ & CDT1 & p.S52N & TBG-CD & 172 \\
\hline Mainz 1 & PDMZ1 & p.S52R & TBG-PD & 29 \\
\hline Mainz 2 & PDMZ2 & p.A64D & TBG-PD & 174 \\
\hline Parana $(*)$ & $\mathrm{CDPa}$ & p.S61C & TBG-CD & 29 \\
\hline Korea $^{a}$ & PDKa & p.E74K & TBG-PD & Não publicado \\
\hline Gary & PDG & p.I96N & TBG-PD & 175 \\
\hline Mainz 3 & PDMZ3 & p.N112L & TBG-PD & 29 \\
\hline Montreal & PDM & p.A113P & TBG-PD & 176 \\
\hline Aborigine $(*)$ & PDA & p.A191T & TBG-PD & 104 \\
\hline Glencoe & PDGe & p.V215G & TBG-PD & 177 \\
\hline No name $(*)$ & CD5 & p.L227P & TBG-CD & 125 \\
\hline Portuguese 3 & CDP3 & p.N233I & TBG-CD & 162 \\
\hline Quebec $(*)$ & PDQ & p.H331Y & TBG-PD & 178 \\
\hline Japan/Kumamoto & PDJ & p.P363L & TBG-PD & 179,180 \\
\hline Heidelberg & PDHg & p.D368G & TBG-PD & Não publicado \\
\hline Kyoto & CDKo & p.S370F & TBG-CD & 181 \\
\hline Mainz 4 & PDMZ4 & p.R381G & TBG-PD & 29 \\
\hline
\end{tabular}




\begin{tabular}{|c|c|c|c|c|}
\hline Mainz 5 & PDMZ5 & p.S382R & TBG-PD & 29 \\
\hline No name & - & $\mathrm{G}>\mathrm{A}$ & TBG-PD & 29 \\
\hline \multicolumn{5}{|l|}{ Deleções } \\
\hline Yonago & CDY & p.D28fsX51 & TBG-CD & 182 \\
\hline Negev & $\mathrm{CDN}$ & p.T38fsX51 & TBG-CD & 183 \\
\hline Nikita & $\mathrm{CDNi}$ & p.P50fsX51 & TBG-CD & 168 \\
\hline No name & CD6 & p.V165fsX168 & TBG-CD & 151 \\
\hline Poland & CDPL & p.D201fsX206 & TBG-CD & 26 \\
\hline No name & CD7 & p.L283fsX301 & TBG-CD & 184 \\
\hline No name (*) & CD8 & p.A329fsX374 & TBG-CD & 185 \\
\hline Japan & CDJ & p.L352fsX374 & TBG-CD & 186,187 \\
\hline Harwichport & $\mathrm{CDH}$ & p.382fsX384 & TBG-CD & 185 \\
\hline NeoIsenburg & CDNI & p.L384fsX402 & TBG-CD & 128 \\
\hline Penápolis & $\mathrm{CDPe}$ & p.K332fsX374 & TBG-CD & 29 \\
\hline \multicolumn{5}{|c|}{ Outras variantes } \\
\hline Slow & $\mathrm{S}$ & p.D171N & TBG-PD & $188-190$ \\
\hline Polimorfismo & Poly & p.L283F & - & 125 \\
\hline Chicago & $\mathrm{CH}$ ou $\mathrm{Cgo}$ & p.Y309F & $\begin{array}{c}\text { Alteração } \\
\text { qualitativa }\end{array}$ & 191,192 \\
\hline
\end{tabular}

Em destaque a mutação descrita no presente estudo.

(*) Mutações que ocorrem em associação com o polimorfismo p.L283F.

a também encontrada uma mutação silenciosa no códon 55: GCA /GCG.

Fonte: adaptado de Pappa T, Ferrara AM, Morkin E, Refetoff S Inherited defects of thyroxinebinding proteins. Best Pract Res Clin Endocrinol Metab 2015:29(5):735-747.

A maioria das variações leva a mudanças quantitativas, ao invés de qualitativas, nos níveis circulantes de TBG, causando deficiência completa ou parcial TBG. Neste cenário, as mutações missense são consideradas menos graves e invariavelmente causam TBG-PD (29). A mutação identificada no presente estudo, p.R35W, segue esta regra e não havia sido descrita na literatura (Tabela 9) (29, 104, 125, 126, 151, 162, 168-192). Uma clássica exceção é a variante TBG-Chicago (p.Y309F), que é encontrada em concentrações normais no soro e apresenta um aumento da resistência à desnaturação térmica e ácida (191,192). Além disso, há raros casos de deficiência clínica de TBG nas quais nenhuma mutação foi encontrada nas regiões codantes e nem em regiões ao redor do gene SERPINA7, sugerindo que fatores regulatórios da expressão do gene podem estar envolvidos (29). Recentemente, uma nova variante em um enhancer específico do tecido hepático, localizado a 20kb abaixo do gene SERPINA7, foi encontrada em 4 famílias, e foi demonstrado que esta mutação compromete a atividade do enhancer in vitro (88).

Observa-se que não há hot spots para a ocorrência de mutações que levem à deficiência de TBG, tampouco correlação entre o grau de deficiência e o local em que a mutação ocorre. Algumas mutações são encontradas nas 
transições em dinucleotídeos CpG, que são sítios frequentes de mutações de ponto em vários outros genes, porém nenhuma mutação foi encontrada em regiões ricas em GC (definida como maior ou igual a 4 consecultivos Gs ou Cs) (193). Deve-se destacar que há uma associação entre o tipo de mutação e a forma como a deficiência se expressa (parcial ou completa), de modo que a maioria das variações causadoras de TBG-CD consiste em mutações nonsense ou deleções com mudança do quadro de leitura, que formam um códon de parada prematuro e geram uma proteína truncada. Já as mutações missense estão mais tipicamente associadas à TBG-PD, o que é compatível com a correlação genótipo-fenótipo encontrada no presente estudo (123).

A figura 17 reporta todas as mutações relatadas na TBG-DP até o presente momento desse trabalho. De acordo com as recomendações da nomenclatura para as mutações, usualmente o nucleotídeo $A$ do códon iniciador ATG é definido como o nucleotídeo +1 . Contudo, no caso do gene SERPINA7, os primeiros 60 nucleotídeos do éxon 1 codificam os 20 aminoácidos do peptídeo sinal, o qual é clivado no momento da síntese da proteína madura. Consequentemente, a metionina codificada pelo ATG no início do éxon 1 é numerada como -20 em todas as publicações para mutações no gene SERPINA7 (194).

Assim, seguindo essa norma para nomenclatura nas mutações no gene SERPINA7, a mutação encontrada neste trabalho consistiu em uma substituição de uma citosina por uma timina na posição do nucleotídeo 163 do éxon 1 do gene SERPINA7, que resultou em alteração no códon 35 da proteína madura (excluindo-se os 20 aminoácidos do peptídeo sinal), com troca de CGG para TGG, resultando na tradução de um triptofano ao invés de uma arginina no códon 35 (p.R35W) da proteína madura. A figura 15 exibe que no éxon 1 do gene SERPINA7, há 10 mutações relatadas, incluindo a desse estudo, e apenas uma, a Allentown (p.H-2Y), encontrada no peptídeo sinal da proteína no códon -2 que resultou na tradução de uma tirosina ao invés de uma histidina (163). No éxon 3 ainda não foram relatadas mutações na TBG-DP no gene SERPINA7. Outra mutação missense no códon 35 foi reportada TBG WanneEickel (p.R35E) (195), assim como também a TBG-PDSD e TBG-CDP1 (ambas no códon 23), TBG-CDT1 e TBG-PDMZ1 (ambas no códon 52) (29,171-173). 


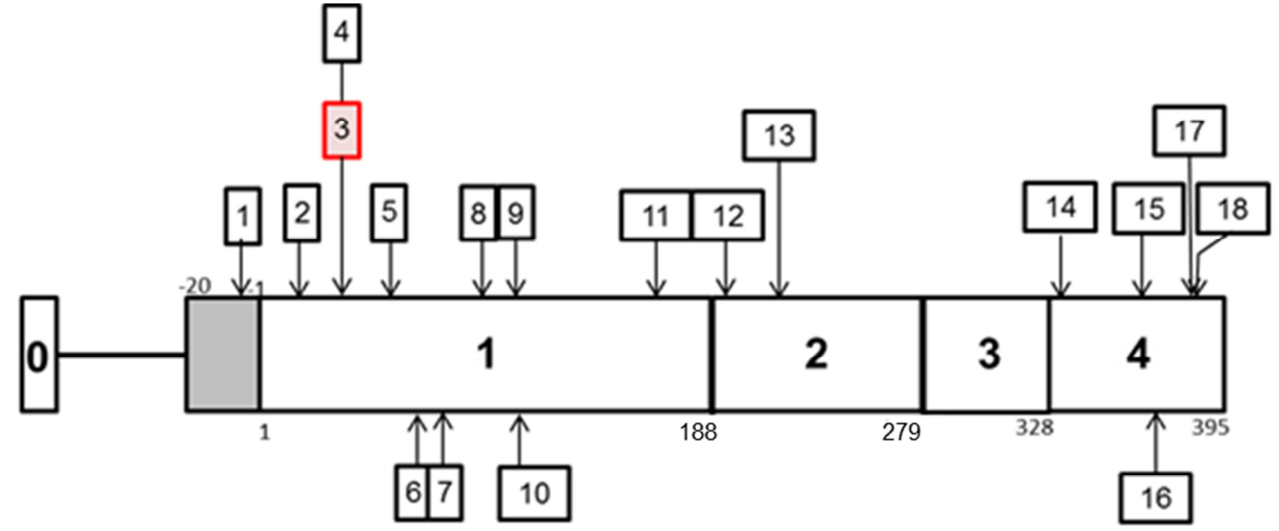
1. Allentown (p.H-2Y)
7 Korea (p.E74K)
13. Glencoe (p.V215G)
2. San Diego* (p.S23T)
8. Gary (p.196N)
14. Quebec* (p.H331Y)
3. Brasília (p.R35W)
9. Mainz 3 (p.N112L)
15. Japan (kumamoto) (p.P363L)
4. Wanner (p.R35E)
10. Montreal (p.A113P)
16. Heidelberg (p.D368G)
5. Mainz 1 (p.S52R)
11. Slow (p.D171N)
17. Mainz 4 (p.R381G)
6. Mainz 2 (p.A64D)
12. Aborigine * (p. A191T)
18. Mainz 5 (p.S382R)

Figura 16 - Representação esquemática da proteína TBG com a numeração dos aminoácidos do peptídeo sinal (retângulo cinza; aminoácidos -20 a -1) e da proteína madura (retângulos brancos; aminoácidos 1 a 395), bem como respectivos números dos éxons codantes da proteína madura (retângulos brancos numerados de 1 a 4). Todas as mutações no gene SERPINA7 descritas na literatura, incluindo a do presente estudo, que resultaram em deficiência parcial de TBG estão apresentadas. A tabela mostra o nome da mutação representada por seus repectivos números na figura, a qual indica sua localização nos éxons 1 , 2, 3, e 4 do gene SERPINA7. Os asteriscos (*) indicam as mutações que ocorrem em associação com o polimorfismo p.L283F. E em destaque de vermelho, a mutação descrita no presente estudo. Fonte: Adaptado de Mannavola D, Vannucchi G, Fugazzola L, Cirello V, Campi I, Radetti G, Persani L, Refetoff S, Beck-Peccoz P. TBG deficiency: description of two novel mutations associated with complete TBG deficiency and review literature. $\mathrm{J}$ Mol Med 2006:84;864-871.

A TBG-DP é a forma mais comum de deficiência herdada de TBG. Porém, muitas vezes seu diagnóstico se torna difícil, principalmente em mulheres heterozigóticas, em que o fenótipo é moderadamente expressso e os exames de rotina são de baixa sensibilidade para a medição da concentração de TBG. Os relatos na literatura mostram que algumas variantes na TBG-DP 
são instáveis (TBG-PDG, TBG-PDA, TBG-PDSD, TBG-PDM TBG-PDQ e TBGPDJ) ou têm menor afinidade de ligação para $T_{4}$ e $T_{3}$ (TBG-PDG, TBGPDA, TBG-PDS TBG-PDSD, TBG-PDM e TBG-PDQ), outras têm o transporte intracelular prejudicado e a secreção (TBG-PDJ e TBG-CDJ), e ainda, algumas exibem um padrão de migração anormal em eletroforese IEF (TBG-PDG, TBGPDM e TBG-PDQ) (Figura 17) (29). Variantes com diminuição da afinidade para $T_{4}$ e $T_{3}$ têm uma diminuição desproporcional na concentração hormonal em relação ao nível de TBG correspondente no soro $(104,163)$.

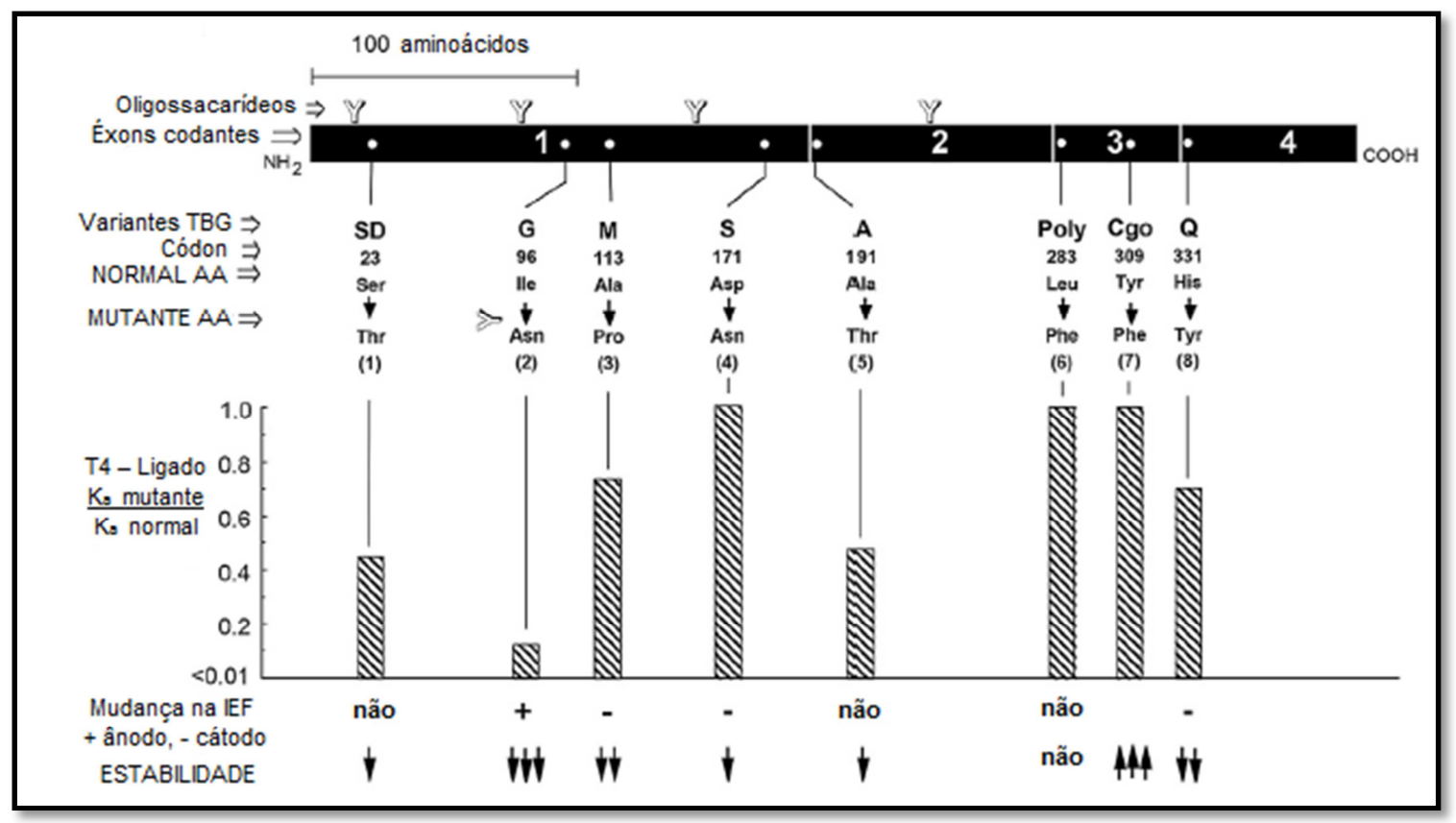

Figura 17 - Propriedades de algumas variantes da TBG que causam deficiência parcial de TBG, como padrão migração em electroforese IEF (focalização isoelétrica), estabilidade e afinidade para ligação ao $T_{4}$. As variantes demonstradas na figura são: -SD, San Diego; - $G$, Gary; -M, Montreal, -S, slow; -A, Aborigine; -Poly, polymorphic; -Cgo, Chicago; and -Q, Quebec. Fonte: adaptado de Pappa T, Ferrara AM, Morkin E, Refetoff $S$ Inherited defects of thyroxinebinding proteins. Best Pract Res Clin Endocrinol Metab 2015:29(5):735-747.

Tem sido relatado que, por várias tentativas, muitos pesquisadores têm procurado estabelecer correlações entre o tipo e grau de deficiência na proteína e a localização da mutação nos domínios da proteína. Mas, comumente, mudanças na estrutura primária causam prejuízo na dobradura da proteína madura podendo alterar a secreção de TBG por levar à retenção intracelular e a degradação das proteínas mutantes (121). A homologia dessa 
proteína com as pertencentes ao grupo serpina evidenciada nos programas de alinhamento de sequencias mostrou que a TBG possui a mesma estrutura vista nos outros membros da família das serpinas inibidoras de proteases. Entretanto, devido à presença exclusiva de uma prolina na posição P8 da região $\mathrm{RCL}$, centro do loop do reativo da TBG, ao invés de uma treonina como em todas as outras serpinas, a TBG não pode formar pontes de hidrogênio entre as cadeias. Desta forma, essa alteração teve um propósito claro de limitar a inserção dentro da região $R C L$ até metade da folha- $A$, provocando uma reversibilidade de transição conformacional na TBG. Desta maneira, a elucidação da estrutura cristalográfica da TBG forneceu novos aprofundamentos sobre os resíduos funcionais da proteína envolvendo a afinidade ao hormônio tireoideano e sua plasticidade estrutural, que podem, desse modo, afetar a regulação alostérica da ligação hormonal e sua liberação (56).

A análise da estrutura da proteína mutante não indicou que a mutação p.R35W da TBG afetaria diretamente o sítio de ligação aos HTs, pois encontrase bem mais distante do T4, diferentemente da mutação San Diego (p.S23T), previamente descrita, que está localizada na proximidade do bolso de ligação à tiroxina (173). Pela análise realizada foi visto que o aminoácido mutado estaria a uma distância de aproximadamente de $17 \AA$ do $\mathrm{T}_{4}$ na estrutura intacta da TBG. Provavelmente o que ocorre é uma perturbação da estrutura, pois é pouco provável que possa afetar diretamente a ligação com a tiroxina.

A arginina não está majoritariamente exposta ao solvente como é comum para resíduos polares/carregados na superfície de proteínas, mas na verdade, ela interage diretamente com outros resíduos na vizinhança (Asn32, Met264 e Asp261) e com duas moléculas de água. Embora estas interações possam ser possíveis com outros resíduos, tais como lisinas e glutaminas, que também são comuns nessa posição, elas não poderiam ser possíveis com um triptofano. E não apenas por essas interações que não são possíveis, mas também pela natureza volumosa e, principalmente, hidrofóbica do triptofano, essa troca resultaria em um fragmento apolar que seria significativamente exposto ao solvente - de acordo com o modelo que foi utilzado nessa análise, com uma área total de $135 \AA^{2}$ - mais da metade da superfície exposta de um triptofano em um tripeptídeo GWG. Tais fragmentos apolares na superfície 
podem resultar em agregação da proteína e/ou enovelamento incorreto. Corroborando com esses achados, a análise da predição in silico do efeito funcional da mutação p.R35W indicou que esta variação é possivelmente danosa, reforçando ainda mais a importância dessa posição para estrutura da proteína na região onde ocorre a mutação.

Outra mutação afetando o códon 35 foi descrita, embora não tenha sido publicada, a mutação Wanner-Eickel, p.R35E, que troca a arginina pelo glutâmico, que também seria problemática por conta da inversão de carga. $\mathrm{E}$ revendo toda a família das serpinas, glutâmicos também são raros nessa posição (2.7\%), mas não tanto quanto triptofanos (29).

Para os outros homólogos da família das serpinas em seres humanos, essa posição também é dominada geralmente por resíduos polares, mas nunca são observados resíduos apolares como triptofanos. Além disso, existe uma mutação documentada na literatura nesta posição por outro homólogo: uma mutação que resulta na troca da arginina por uma cisteína na posição equivalente encontrada nesse estudo na alfa-1-antitripsina resultando em um fenótipo de deficiência de TBG (196). Por essas razões, acredita-se que a TBG e seus homólogos dentro da família das serpinas poderiam ser igualmente afetados por mutações nesta posição que iriam romper a rede de interações para com seus vizinhos na estrutura nativa.

Em síntese, o conjunto de resultados obtidos nesse estudo sugerem fortemente que a nova mutação p.R35W identificada na TBG resulta em anormalidade estrutural grave, que pode acarretar agregação da proteína ou enovelamento incorreto e provável retenção intracelular e degradação, o que justifica a detecção de níveis muito baixos de TBG circulante, e, em última análise, o fenótipo de TBG-PD nos indivíduos afetados. 
CONCLUSÃO 


\subsection{CONCLUSÃO}

- O presente estudo descreveu uma nova mutação no gene SERPINA7 (p.R35W) associado a TBG-PD em três irmãos: uma mulher em heterozigose e dois homens hemizigotos.

- A mulher expressa um padrão de inativação do cromossomo X 20:80, ligeiramente desviado, sugerindo que o desvio do padrão de inativação seja o mecanismo fundamental na expressão fenotípica nesse caso.

- A predição in silico do impacto funcional da mutação p.R35W indicou que esta variação é possivelmente danosa.

- A análise estrutural revelou que:

- O resíduo 35 encontra-se distante $17 \AA ̊$ do sítio de ligação do T4.

- R35W localiza-se na hélice-hA cuja cadeia lateral encontra-se na superfície da TBG, na região exposta ao solvente.

- A mutação rompe as interações eletrostáticas do resíduo $35 \mathrm{com}$ seus vizinhos, portanto, gera fragmentos apolares na superfície da TBG, não solúveis no sangue, que então resultam em agregação e/ou enovelamento incorreto da proteína.

- A mutação p.R35W é patogênica.

- Os achados justificam o fenótipo de TBG-PD nessa família, pois o enovelamento incorreto da proteína resulta em retenção intracelular, e/ou compromete a sua secreção e função de transporte do $T_{4}$ no sangue.

- Por fim, este estudo contribuiu para uma melhor compreensão das bases moleculares e da relação estrutura/função da TBG e acrescentou informações originais à casuística internacional dentro da série dos defeitos hereditários nas proteínas carreadoras dos hormônios tireoideanos no soro. 
REFERÊNCIAS 


\subsection{REFERÊNCIAS}

1. Dângelo JG, Fattini CA. Anatomia humana básica. São Paulo: Atheneu, 2002.

2. Moore KL, Persaud TVN. Embriologia Clínica. $8^{\mathrm{a}}$ ed. Rio de Janeiro: Guanabara Koogan, 2008.

3. Kronenberg HM, Melmed S, Polonsky KS, Larsen PR. Williams tratado de endocrinologia. 11 ed. Rio de Janeiro: Elsevier, 2010.

4. Junqueira, L. C. U. \& Carneiro, J. Histologia básica: texto e atlas. 12. ed. Rio de Janeiro: Guanabara Koogan, 2013.

5. Yen PM. Physiological and molecular basis of thyroid hormone action. Physiol Rev. 2001;81:1097-142.

6. Brent GA . Mechanisms of thyroid hormone action. J Clin Invest 2012;122: 3035-3043.

7. Cheng SY, Leonard JL, Davis PJ. Molecular aspects of thyroid hormone actions. Endocr Rev 2010;31:139-170,

8. Oetting A, Yen PM. New insights into thyroid hormone action. Best Pract Res Clin Endocrinol Metab 2007; 21: 193-208.

9. Oppenheimer JH, Schwartz HL, Lane JT, Thompson MP. Functional relationship of thyroid hormone-induced lipogenesis, lipolysis, and thermogenesis in the rat. J Clin Invest 1991;87: 125-132.

10. Friesema EC, Jansen J, Visser TJ. Thyroid hormone transporters. Biochem Soc Trans. 2005; 33:228-32.

11. Lúcio Vilar. Endocrinologia Clínica. $5^{\underline{a}}$ ed. Rio de Janeiro: Editora Guanabara Koogan, 2013. 
12. Ribeiro RCJ, Apriletti JW, West BR, Wagner RL, Fletterick RJ, Schaufele F, Baxter JD. The molecular biology of thyroid homone action. Ann Ny Acad Sci, 1995;758: 366-89.

13. Maia AL, Kim BW, Huang SA, Harney JW, Larsen PR. Type 2 iodothyronine deiodinase is the major source of plasma $T_{3}$ in euthyroid humans. J Clin Invest 115: 2524-2533, 2005.

14. Larsen PR, Berry MJ. Type I iodothyronine deiodinase: unexpected complexities in a simple deiodination reaction. Thyroid. 1994; 4:357-62.

15. Berry MJ, Banu L, Larsen PR. Type I iodothyronine deiodinase is a selenocysteine-containing enzyme. Nature 1991;349:438-40.

16. Azevedo MF, SB., Maioa L., Leal E. Interpretação dos testes de função tireoideana, in Endocrinologia Clínica, Rio de Janeiro 2006; p. 219-239.

17. St. Germain DL, Galton VA. The deiodinase family of selenoproteins. Thyroid 1997;7:655-68.

18. Kuiper GG, Kester MH, Peeters RP, Visser TJ. Biochemical mechanisms of thyroid hormone deiodination. Thyroid 2005;15:787-98.

19. Gereben, B et al. Cellular and Molecular Basis of Deiodinase-regulated Thyroid Hormone Signaling. Endocr Rev. 2008; Dec 29(7):898-938.

20. Bianco, AC et al., Biochemistry, cellular and molecular biology, and physiological roles of the iodothyronine selenodeiodinases. Endocr Rev 2002;23 (1):p.38-39.

21. Salvatore D, Tu H, Harney JW, Larsen PR. Type 2 iodothyronine deiodinase is highly expressed in human thyroid. J Clin Invest 1996;98:962-8.

22. Ishii $\mathrm{H}$, Inada $\mathrm{M}$, Tanaka $\mathrm{K}$, Mashio $\mathrm{Y}$, Naito $\mathrm{K}$, Nishikawa $\mathrm{M}$, et al. Triiodothyronine generation from thyroxine in human thyroid: enhanced conversion in Graves' thyroid tissue. J Clin Endocrinol Metab 1981;52:1211-7 
23. Shupnik MA, Ridgway EC, Chin WW. Molecular biology of thyrotropin. Endocr Rev 1989;10: 459-475.

24. Larsen PR, Davies TF, Schlumberger M-J, Hay ID. Thyroid physiology and diagnostic evaluation of patients with thyroid disorders. In: Larsen PR, Kronenberg HM, Melmed S, Polonsky KS, editors. Williams' textbook of endocrinology. $10^{\text {th }}$ ed. Philadelphia: W.B. Saunders, 2003;p.331-73.

25. Schomburg L, Bauer K.. Thyroid hormones rapidly and stringently regulate the messenger RNA levels of the thyrotropin-releasing hormone (TRH) receptor and the TRH-degrading ectoenzyme. Endocrinology 1995;136:34805.

26. Scanlon MF. Thyrotropin-releasing hormone and thyroid-stimulating hormone. In: DeGroot LJP, Jameson JL, editors Endocrinology. $4^{\text {th }}$ ed. Philadelphia: W.B. Saunders, 2001 ;p.1279-89.

27. Goichot B, Weibel L, Chapotot F, Gronfier C, Piquard F, Brandenberger G. Effect of the shift of the sleep-wake cycle on three robust endocrine markers of the circadian clock. Am J Physiol 1998;275:E243-E248.

28. Oppenhenheimer $\mathrm{JH}$. Role of plasma proteins in the binding, distribution, and metabolismo of the thyroid hormones. N Engl J Med 1968; 278:1153-62.

29. Pappa T, Ferrara AM, Morkin E, Refetoff S. Inherited defects of thyroxinebinding proteins. Best Pract Res Clin Endocrinol Metab. 2015;29(5):735-747.

30. Janssen OE, Golcher HMB, Grasberger H, et al., Characterization of thyroxine-binding globulin cleaved by human leukocyte elastase. J Clin Endocrinol Metab 2002;87:1217-22.

31. Sunthornthepvarakul T, Likitmaskul S, Ngowngarmratana S et al., Familial dysalbuminemic 1998;83:1448-54.

32. Refetoff S., Inherited Thyroxine-Binding Globulin Abnormalities in Man. Endocr Rev 1989;10(3):275-93. 
33. Blake CC, geisow MJ, oatley SJ et al. Structure of prealbumin: secondary, terciary and quaternary interactions determined by fourier refinement at $1.8 \mathrm{~A}$. J Mol Biol. 1978;121:339-56.

34. Peters Jr T. Serum albumin. Adv Protein Chem 1985;37:161e245.

35. Hollander CS, Bernstein G, Oppenheimer JH. Abnormalities of thyroxine binding in analbuminemia. J Clin Endocrinol Metab 1968;28:1064e6.

36. Utiger, RD. The thyroid: physiology, thyrotoxicosis, hypothyroidism, and the painful thyroid. In Endocrinology and Metabolism (Felig, PF, Baxter, JD \& Frohman, CA, eds.), 1995; pp. 435-519. MacGraw-Hill, New York.

37. Ribeiro RCJ, Apriletti JW, Wagner RL, West BL, Feng W, Huber R, et al. Mechanisms of Thyroid Hormone Action: Insights from X-ray Crystallographic and Functional Studies. Recent Prog Horm Res 1998;53:351-94.

38. Hennemann G, Docter R, Friesema EC, de Jong M, Krenning EP, Visser TJ. Plasma membrane transport of thyroid hormones and its role in thyroid hormone metabolism and bioavailability. Endocr Rev 2001; 22:451-76.

39. Hennemann, G., et al., Plasma membrane transport of thyroid hormones and its role in thyroid hormone metabolism and bioavailability. Endocr Rev, 2001. 22(4): p. 451-76.

40. Friesema, EC., et al., Thyroid hormone transporters. Vitam Horm. 2005;70: p.137-67.

41. Barra GB, Velasco LF, Pessanha RP, Campos AM, Moura FN, Dias, SM, Polikarpov I, Ribeiro RC, Simeoni LA, Neves FA. Mecanismo molecular da ação do hormônio tireoideano. Arq Bras Endocrinol Metabol. 2004;48, 25-39.

42. Velasco, LFR., et al. Thyroid hormone response element organization dictates the composition of active recoeptor. J Biol Chem 2007;282(17): p. 12458-66.

43. Germain, P., Staels, B.,Dacquet,. C., Spedding, M \& Laudet, V. Overview of nomenclature of nuclear receptors. Pharmacol Rev 2006; 58, 685-704. 
44. Evans, RM. The steroid and Thyroid hormone receptor superfamily. Science. 1988;240, 889-895.

45. Beato, M. Transcriptional control by nuclear receptors. The Faseb Journal. $1991 ; 5$ (7) 2044-2051.

46. Ribeiro, RCJ, Kushner,PJ, and Baxter,JD; The nuclear hormone receptor gene superfamily .Annu Rev Med. 1995;46: p.443-53.

47. Sap J, Munoz A, Damm K, Goldberg Y, Ghysdael J, Leutz A Beug H \& Vennstrom $B$. The c-erb-A protein is a high-affinity receptor for thyroid hormone. Nature. 1986;324, 635-640.

48. Weinberger C, Thompson CC,Ong ES, Lebo R, Gruol DJ \& Evans RJ, 1986. The c-erb-A gene encodes a thyroid hormone receptor. Nature. 324, 641-646.

49. Lazar, MA. Thyroid hormone receptor: multiple forms, multiple possibilities. Endocr Rev. 1993;14(2): p.184-93.

50. Ribeiro RCJ, Kushner PJ and Baxter JD. The nuclear hormone receptor gene superfamily. Annu Rev Med. 1995;46:p.443-53.

51. Chen JD, Evans RM. A transcriptional co-repressor that interacts with nuclear hormone receptors. Nature.1995;377:151-7.

52. McKenna NJ, Lanz RB and O'Malley BW. Nuclear receptor coregulators: cellular and molecular biology. Endocr Rev. 1990;20(3): p. 321-44.

53. Ribeiro RCJ, Kushner PJ, Apriletti JW, West BL \& Baxter JD. Thyroid hormone alters in vitro DNA binding of monomers and dimers of thyroid hormone receptor. Mol. Endocrinol. 1992; 6:1142-1152.

54. Refetoff S 2012 Thyroid hormone serum transport proteins: structure, properties, genes and transcriptional regulation. In: DeGroot L. Thyroid Disease Manager. 
55. Flink IL, Bailey TJ, Gustefson TA, Markham BE, Morkin E. Complete amino acid sequence of human thyroxine-binding globulin deduced from cloned DNA: Close homology to the serine antiproteases. Proc Natl Acad Sci U S A 1986; 83:7708-7712.

56. Zhou A, Wei Z, Read RJ, Carrell RW. Structural mechanism for the carriage and release of thyroxine in the blood. Proc Natl Acad Sci U S A 2006; 103:13321-13326.

57. Murata $Y$, Magner JA, Refetoff $S$. The role of glycosylation in the molecular conformation and secretion of thyroxine-binding globulin. Endocrinology 1986; 118:1614-1621

58. Kambe F, Seo H, Mori Y, Murata Y, Janssen OE, Refetoff S, Matsui N. An additional carbohydrate chain in the variant thyroxine-binding globulin-Gary (TBGAsn-96) impairs its secretion. Mol Endocrinol 1992; 6:443-449

59. Robbins J. Thyroxine transport and the free hormone hypothesis. J Clin Endocrinol Metab 1992; 131:546-547.

60. Gärtner R, Henze R, Horn K, Pickardt CR, Scriba PC. Thyroxine-binding globulin: Investigation of microheterogeneity. J Clin Endocrinol Metab 1981; 52:657-664.

61. Refetoff S, Murata Y, Vassart G, Chandramouli V, Marshall JS. Radioimmunoassays specific for the tertiary and primary structures of thyroxine-binding globulin (TBG): Measurement of denatured TBG in serum. J Clin Endocrinol Metab 1984; 59:269-277.

62. Tabachnick M, Giorgio NA, Jr. Thyroxine-protein interactions. II. The binding of thyroxine and its analogues to human serum albumin. Arch Biochem Biophys 1964; 105:563-569.

63. Refetoff S, Hagen S, Selenkow HA. Estimation of the T4 binding capacity of serum TBG and TBPA by a single T4 load ion exchange resin method. J Nucl Med 1972; 13:2-12, 
64. Grimaldi $\mathrm{S}$, Edelhoch $\mathrm{H}$, Robbins J. Effects of thyroxine binding on the stability, conformation, and fluorescence properties ofthyroxine-binding globulin. Biochemistry (Mosc) 1982; 21:145-150.

65. Refetoff S, Fang VS, Marshall JS. Studies on human thyroxine-binding globulin (TBG): IX. Some physical, chemical and biological properties of radioiodinated TBG and partially desialylated TBG (STBG). J Clin Invest 1975; 56:177-187.

66. Law RHP et al., An overview of the serpin superfamily. Genome Biology. 2006; 7:216.

67. Irving JA, Pike RN, Lesk AM, Whisstock JC: Phylogeny of the serpin superfamily: implications of patterns of amino acid conservation for structure and function. Genome Res. 2000;10:1845-1864.

68. Carrell RW, Aulak KS, Owen MC. The molecular pathology of the serpins. Mol Biol Med. 1989; Feb:6(1):35-42.

69. Silverman GA, et al. The serppin are expanding superfamily of struturally similar but functionally diverse protein. The jornal of boil chem vol $2001 ; 276$ (36), 33293-33296.

70. Pemberton PA, Stein PE, Pepys MB, Potter JM, Carrell RW: Hormone binding globulins undergo serpin conformational change in inflammation. Nature 1988; 336:257-258.

71. Nagata K: Hsp47: a collagen-specific molecular chaperone. Trends Biochem Sci. 1996;21:22-26.

72. Zou Z, Anisowicz A, Hendrix MJ, Thor A, Neveu M, Sheng S, Rafidi K, Seftor E, Sager R: Maspin, a serpin with tumor-suppressing activity in human mammary epithelial cells. Science. 1994;263:526-529.

73. Patson, P. A. Serpins and other serine protease inhibitors. Immunology Today. 2000;21(7):354. 
74. Irving JA., Pike RN., Lesk AM \& Whisstock JC. Phylogeny of the serpin superfamily: implications of patterns of amino acid conservation for structure and function. Genome Research. 2000;10 (12):1845-1864.

75. Ragg $\mathrm{H}$, Lokot $\mathrm{T}$, Kamp PB, Atchley WR \& Dress A. Vertebrate serpins: construction of a conflict-free phylogeny by combining exon-intron and diagnostic site analyses. Molecular Biology and Evolution. 2001;18(4):577584.

76. Nakashima T, Pak SC, Silverman GA, Spring PM, Frederick MJ, \& Clayman GL. Genomic cloning, mapping, structure and promoter analysis of HEADPIN, a serpin which is down-regulated in head and neck cancer cells. Biochimica Biophysics Acta. 2000;1492:441-446.

77. Janciauskiene S. Conformational properties of serine proteinase inhibitors (serpins) confer multiple pathophysiological roles. 2001;Mar 26;1535(3):22135.

78. Carrell, RW, Pemberton PA., Boswell DR. The serpins: evolution and adaptation in a family of protease inhibitors. Cold Spring Harbor Symposia Quantitative Biology, 1987; 52:527-535.

79. Gettins, GWP. Keeping the serpin machine running smoothly. Genome Research. 2000; 10:1833-1835.

80. Huntington JA., Read RJ, \& Carrell RW. Structure of a serpin-protease complex shows inhibition by deformation. Nature. 2000;407, 923-926.

81. Loebermann HR, Tokuoka J. Deisenhofer, \& R. Huber, Human alpha 1proteinase inhibitor. Crystal structure analysis of two crystal modifications, molecular model and preliminary analysis of the implications for function: $\mathrm{J}$ Mol Biol, 1984; 177: 531-57.

82. Bruch $M$, Weiss $V$ and Engel J. Plasma serine proteinase inhibitors (serpins) exhibit major conformational changes and a large increase in conformational stability upon cleavage at their reactive sites. J. Biol. Chem. 1988; 263:16626-16630. 
83. Qi X, Loiseau F, Chan WL, Yan Y, Wei Z, Milroy LG, Myers RM, Ley SV, Read RJ, Carrell RW, Zhou A. Allosteric modulation of hormone release from thyroxine and corticosteroid-binding globulins. J Biol Chem 2011; 286:1616316173

84. Grasberger H, Henriette MBG, Fingerhut A, Janssen OE. Loop variants of the serpin thyroxine-binding globulin: implications for hormone release upon limited proteolysis. Biochem J. 2002; Jul 1;365(Pt 1): 311-316.

85. Trent JM, Flink IL, Morkin E, Van Tuinen P, Ledbetter DH. Localization of the human thyroxine-binding globulin gene to the long arm of the $X$ chromosome (Xq21-22). Am J Hum Genet. 1987; 41:428-435.

86. Gent DV, Serpins structure, function and molecular evolution. The international Journal of Biochemistry \& Cell Biology. 2003; 35:1536-1547.

87. Hayashi $\mathrm{Y}$, Mori $\mathrm{Y}$, Janssen $\mathrm{OE}$, et al. Human thyroxine-binding globulin gene: complete sequence and transcriptional regulation. Mol Endocrinol. 1993; 7:1049-60.

88. Ferrara AM, Pappa T, Fu J, et al. A novel mechanism of inherited TBG deficiency: mutation in a liver-specific enhancer.J Clin Endocrinol Metab 2015;100:E173-81.

89. Nakashima T, Pak SC, Silverman GA, Spring PM, Frederick MJ, \& Clayman GL. Genomic cloning, mapping, structure and promoter analysis of HEADPIN, a serpin which is down-regulated in head and neck cancer cells. Biochimica Biophysics Acta. 2000;1492:441-446.

90. Grimaldi S, Edelhoch H, Robbins J. Effects of thyroxine binding on the stability, conformation, and fluorescence properties of thyroxine-binding globulin. Biochemistry (Mosc) 1982; 21:145-150.

91. Cody V. Thyroid hormone interactions: Molecular conformation, protein binding and hormone action. Endocr Rev 1980; 1:140-166. 
92. Hocman G. Human thyroxine binding globulin. Rev Physiol Biochem Pharmacol 1981; 81:45-88 .

93. Tabachnick M, Giorgio NA, Jr. Thyroxine-protein interactions. II. The binding of thyroxine and its analogues to human serum albumin. Arch Biochem Biophys 1964; 105:563-569.

94. Cavalieri RR, McMahon FA, Castle JN. Preparation of 125I-labeled human thyroxine-binding alpha globulin and its turnover in normal and hypothyroid subjects. J Clin Invest 1975; 56:79-87.

95. Larsen PR. Salicylate-induced increases in free triiodothyronine in human serum: Evidence of inhibition of triiodothyronine binding to thyroxine-binding gloublin and thyroxine-binding prealbumin. J Clin Invest 1972; 51:1125-1134.

96. Bartalena L, Tata JR, Robbins J. Characterization of nascentand secreted thyroxine-binding globulin in cultured human hepatoma (Hep G2) cells. J Biol Chem 1984; 259:13605.

97. Murata Y, Same D, Horwitz AL, Lecocq R, Aden DP, Knowles BB, Refetoff S. Characterization of thyroxine-binding globulin (TBG) synthesis in a human hepatoma cell line. J ClinEndocrinol Metab. 1985;60:472

98. Flink IL, Bailey TJ, Gustefson TA, Markham BE, Morkin E. Complete amino acid sequence of human thyroxine-binding globulin deduced from cloned DNA: close homology to the serine antiproteases. Proc Natl Acad Sci USA. 1986; 83:7708

99. Hammond GL, Smith CL, Goping IS, Underhill DA, Harley MJ, Reventos J, Musto NA, Gunsalus GL, Bardin CW. Primary structure of human corticosteroid binding globulin, deduced from hepatic and pulmonary cDNAs, exhibits homology with serine protease inhibitors. Proc Natl Acad Sci. 1987; 84:5153.

100. Zinn AB, Marshall JS, Carlson DM Carbohydrate structures of thyroxinebinding globulin and their effects on hepatocyte membrane binding. $J$ Biol Chem 1978;253:6768. 
101. Gartner R, Henze R, Horn K, Pickardt CR, Scriba PC . Thyroxine-binding globulin: investigation of microheterogeneity. J Clin Endocrinol Metab 1981; $52: 65742$.

102. Marshall JS, Pensky J, Green AM Studies on human thyroxine-binding globulin. IV. The nature of slow thyroxine-binding globulin. J Clin Invest 1972; $51: 3173$.

103. Cheng S-Y, Morrone S, Robbins J Effect of deglycosylation on the binding and immunoreactivity of human thyroxine-binding globulin. J Biol Chem 1979; 254:8830.

104. Takeda K, Mori Y, Sobieszczyk S, Seo H, Dick M, Watson F, Flink IL, Seino S, Bell Gl, Refetoff S. Sequence of the variant thyroxine-binding globulin of Australian Aborigines: only one of two amino acid replacements is responsible for its altered properties.J Clin Invest. 1989;83:1344.

105. Marshall JS, Pensky J Studies on thyroxine-binding globulin (TBG). III. Some physical characteristics of TBG and its interaction with thyroxine. Arch Biochem Biophys. 1971;146:76.

106. Robbins J, Cheng S-Y, Gershengorn MC, Glinoer D, CahnmannHJ, Edelnoch $\mathrm{H}$ Thyroxine transport proteins of plasma. Molecular properties and biosynthesis. Recent Prog Horm Res. 1978;34:477.

107. Mendel CM, Weisinger RA, Cavalieri RR. Uptake of 3,5,3'triiodothyronine by the perfused rat liver: return to the free hormone hypothesis. Endocrinology. 1988;123:1817

108. Chan V, Besser GM, Landon J. Effects of estrogen on urinary thyroxine excretion. Br Med J. 1972;4:699

109. Mendel CM, Weisinger RA, Jones AL, Cavalieri RR. Thyroid hormonebinding proteins in plasma facilitate uniform distribution of thyroxine within tissues: a perfused rat liver study. Endocrinology. 1987;120:1742. 
110. Pemberton PA, Stein PE, Pepys MB, Potter JM, Carell RW Hormone binding globulins undergo serpin conformational change in inflammation. Nature. 1988; 336:257.

111. Beierwaltes $\mathbf{W H}$, Robbins $J$ Familial increase in the thyroxine-binding sites in serum alpha globulin. J Clin Invest. 1959; 38:1683.

112. Marshall JS, Levy RP, Steinberg AG. Human thyroxine-binding globulin deficiency: a genetic study. N Engl J Med. 1966;274:1469.

113. Nikolai TF, Seal US. X-chromosome linked familial decrease in thyroxinebinding globulin deficiency. J Clin Endocrinol Metab. 1966;25:835.

114. Refetoff S, Selenkow HA. Familial thyroxine-binding globulin deficiency in a patient with Turner's syndrome (XO): genetic study of a kindred. N Engl J Med. 1968;278:1081.

115. Nicoloff JT, Dowling JT, Patton DD. Inheritance of decreased thyroxinebinding by the thyroxine-binding globulin. J Clin Endocrinol Metab.1964;24:294

116. Moloshok RE, Hsu LYF, Seal US, Hirschhorn K. Partial thyroxine-binding globulin deficiency in a family Pediatrics. 1969;44:518.

117. Refetoff S, Robin NI, Alper CA. Study of four new kindreds with inherited thyroxine-binding globulin abnormalities: Possible mutations of a single gene locus. J Clin Invest 1972; 51:848-867.

118. Kobayashi H, Sakurai A, Katai M, Hashizume K. Autosomally transmited low concentration of thyroxine-binding globuline. Thyroid. 1999; 9:159-163.

119. Burr WA, Ramsden DB, Hoffenberg R. Hereditary abnormalities of thyroxine-binding globulin concentration J Med 1980; 49:295.

120. Refetoff S, Larsen PR. Transport, cellular uptake and metabolism of thyroid hormone. In: DeGroot LJ (ed) Endocrinology, Ed 2. W.B. Saunders, Philadelphia, 1989; pp 541-561. 
121. Refetoff S 2015 Abnormal thyroid hormone transport. In: DeGroot L. Thyroid Disease Manager. Disponível em www.thyroidmanager.org. Acessado em 18 de abril, 2016.

122. Sunthornthepvarakul T, Likitmaskul S, Ngowngarmratana S, Angsusingha $\mathrm{K}$, Sureerat $\mathrm{K}$, Scherberg $\mathrm{NH}$, Refetoff $\mathrm{S}$. Familial dysalbuminemic hypertriiodothyroninemia: a new dominantly inherited albumin defect. J Clin Endocrinol Metab. 1998; 83:1448-1454.

123. Refetoff $\mathrm{S}$, Murata $\mathrm{Y}$, Mori $\mathrm{Y}$, Janssen OE, Takeda $\mathrm{K}$ Hyashi $\mathrm{Y}$ Thyroxine-binding globulin: organization of the gene and variants. Horm Res. 1996; 45:128-138.

124. Okamoto H, Mori $Y$, Tani $Y$, Nakagomi $Y$, Sano $T$, Ohyama K, Saito H, Oiso $\mathrm{Y}$. Molecular analysis of females manifesting thyroxine-binding globulin (TBG) deficiency: selective X-chromosome inactivation responsible for the difference between phenotype and genotype in TBG-deficient females. J Clin Endocrinol Metab 1996; 81:2204-2208.

125. Mori Y, Takeda K, Charbonneau M, Refetoff S. Replacement of Leu ${ }^{227}$ by Pro in thyroxine-binding globulin (TBG) is associated with complete TBG deficiency in three of eight families with this inherited defect. J Clin Endocrinol Metab.1990; 70:804-809.

126. Reutrakul S, Dumitrescu A, Macchia P, Moll GWJ, Vierhapper H, Refetoff $S$. Complete thyroxine-binding globulin (TBG) deficiency in two families without mutations in coding or promoter regions of the TBG gene: in vitro demonstration of exon skipping. J Clin Endocrinol Metab. 2002; 87:1045-1051

127. Janssen $\mathrm{OE}$, Refetoff $\mathrm{S}$. In-vitro expression of thyroxine-binding globulin (TBG) variants: Impaired secretion of TBGPRO-227 but not TBGPRO-113. J Biol Chem. 1992; 267:13998-14004.

128. Moeller LC, Fingerhut A, Lahner H, Grasberger H, Weimer B, Happ J, Mann K, Janssen OE. C-Terminal Amino Acid Alteration rather than Late Termination Causes Complete Deficiency of Thyroxine-Binding Globulin CDNeulsenburg. J Clin Endocrinol Metab 2006; 91:3215-3218 
129. Ferrara AM, Cakir M, Henry PH, et al. Coexistence of THRB and TBG gene mutations in a Turkish family. J Clin Endocrinol Metab. 2013;98:E1148E51.

130. Yamamori I, Mori $Y$, Miura $Y$, Tani $Y$, Imamura S, Oiso $Y$, Seo H. Gene screening of 23 Japanese families with complete thyroxine-binding globulin deficiency: Identification of a nucleotide deletion at codon 352 as a common cause. Endocr J 1993; 40:563-569.

131. Takeda $K$, lyota $K$, Mori $Y$, Tamura $Y$, Suehiro $T$, Kubo $Y$, Refetoff $S$, Hashimoto K. Gene screening in Japanese families with complete deficiency of thyroxine-binding globulin demonstrates that a nucleotide deletion at codon 352 may be a race specific mutation. Clin Endocrinol (Oxf) 1994; 40:221-226.

132. Sarne DH, Refetoff S, Murata $Y$, Dick M, Watson F. Variant thyroxinebinding globulin in serum of Australian Aborigines. A comparison with familial TBG deficiency in Caucasians and American Blacks. J Endocrinol Invest 1985; 8:217-224.

133. Sarne DH, Refetoff S, Nelson JC, Dussault J. A new inherited abnormality of thyroxine-binding globulin (TBG-San Diego) with decreased affinity for thyroxine and triiodothyronine. J Clin Endocrinol Metab 1989; 68:114-119.

134. Dick $\mathrm{M}$, Watson $\mathrm{FA}$ possible variant of thyroxine-binding globulin in Australian Aborigines. Clin Chim Acta 1981;116:361.

135. Brown SK, Bellisario R Measurement of thyroxine bindingglobulin (TBG) levels from dried blood spot specimens: detectionof TBG deficiency and TBG excess in infants. In: Genetic Disease: Screening and Management. Alan R. Liss, Inc., New York, 1986; 373-384.

136. Lyon ICT Screening for hypothyroidism: The New Zealand experience. In: Naruse $\mathrm{H}$, Irie M (eds), Neonatal Screening. International Congress, Series 606. Excerpta Medica, Amsterdam, 1983 ;111-112. 
137. Griffiths KD, Virdi NK, Rayner PHW, Green A Neonatal screening for congenital hypothyroidism by measurement ofplasma thyroxine and thyroid stimulating hormone concentrations.Br Med J.1985;291:117.

138. Refetoff S, Charbonneau M, Same DH, Takamatsu J, Dussault JH Resistance to thyroid hormones and screening for high thyroxine at birth. In: Delange F, Fisher DA, Glinoer D (eds) Research for Congenital Hypothyroidism. Plenum PublishingCorp., New York, 1989; 165-172.

139. Viscardi RM, Shea M, Sriwantanakul K, McCormick K Hyperthyroxinemia in newborns due to excess Thyroxine-binding globulin. $N$ Engl $\mathrm{J}$ Med. 1983;309:897.

140. Mori $Y$, Miura Y, Takeuchi H, Igarashi Y, Sugiura J, Oiso Y. Gene amplification as a cause for inherited thyroxine-binding globulin excess in two Japanese families. J Clin Endocrinol Metab. 1995; 80:3758-3762.

141. Chiurrazi P,Schwartz CE, Gercz J, Neri G - XLMR. genes: update 2007. Eur J Hum Genet. 2008; 18: 1-13.

142. Lyon MF - Gene action in the X-chromosome of the mouse (Mus musculus L. Nature. 1961;190: 372-373.

143. Boumil RM, Lee JT - Forty years of decoding the silence in Xchromosome inactivation. Hum Mol Genet. 2001;10: 2225-2232.

144. Amos-Landgraf JM, Cottle A, Plenge RM, Friez M, Schwartz CE, Longshore J, Willard HF - X chromosome-inactivation patterns of 1,005 phenotypically unaffected females. Am J Hum Genet. 2006;79: 493-499.

145. Nussbaum, Robert L.; Mclnnes, Roderick R.; Willard, Huntington F. Thompson \& Thompson - Genética Médica. Sétima Edição. Editora Guanabara Koogan S.A., Rio de Janeiro, RJ, 2008;pp525 .

146. Refetoff S, Murata Y. X-chromosome-linked inheritance of the variant thyroxine-binding globulin in Australian Aborigines. J Clin Endocrinol Metab. 1985; 60:356-360. 
147. Puck JM, Willard HF $\mathrm{X}$ inactivation in females with $\mathrm{X}$-linked disease. $\mathrm{N}$ Engl J Med. 1998;338: 325-328.

148. Medeiros-Neto GA, Stanbury JB. Inherited disorders of the thyroid system. Boca Raton, FL: CRC Press; 1994.

149. Miller SA, Dykes DD, Polesky HF. A simple salting out procedure for extracting DNA from human nucleated cells. Nucleic Acids Res. 1988; $11 ; 16(3): 1215$.

150. Inagaki A, Miura $Y$, Mori $Y$, Saito $H$, Seo $H$, Oiso $Y$. Gene screening of thyroxine-binding globulin (TBG) deficiencies in the Japanese: only two mutations account for TBG deficiencies in the Japanese. J Clin Endocrinol Metab.1996;81(2):580-5.

151. Li P, Janssen OE, Takeda $\mathrm{K}$, Bertenshaw RH, Refetoff S. Complete thyroxine-binding globulin (TBG) deficiency caused by a single nucleotide deletion in the TBG gene. Metabolism.1991; 40:1231-1234.

152. Allen RC, Zoghbi HY, Moseley AB, Rosenblatt HM, Belmont JW Methylation of Hpall and Hhal sites near the polymorphic CAG repeat in the human androgen-receptor gene correlates with $\mathrm{X}$ chromosome inactivation. Am J Hum Genet. 1992; 51:1229-1239.

153. Snyder PJ, Utiger RD. Response to thyrotropin-relasing hormoe (TRH) in normal man. J Clin Endocrinol Metab.1972;34:380-385.

154. Bittel DC, Theodoro MF, Kibiryeva N, Fischer W, Talebizadeh Z, Butler MG. Comparison of $X$-chromosome inactivation patterns in multiple tissues from human females. J Med Genet 2007;45:309-313.

155. Bleicher L, Lemke N, Garratt RC. Using amino acid correlation and community detection algorithms to identify functional determinants in protein families. PLoS One. 2011;6(12):e27786.

156. Finn RD, Coggill P, Eberhardt RY, Eddy SR, Mistry J, Mitchell AL, Potter SC, Punta M, Qureshi M, Sangrador-Vegas A, Salazar GA, Tate J, Bateman A. 
The Pfam protein families database: towards a more sustainable future. Nucleic Acids Res. 2016:44(D1):D279-85.

157. Feyfant E, Sali A, Fiser A. Modeling mutations in protein structures. Protein Sci. 2007:16(9):2030-41.

158. Sali A, Blundell TL Comparative protein modelling by satisfaction of spatial restraints. J Mol Biol. 1993:234:779-815.

159. B.Lee and F.M.Richards. The interpretation of protein structures: estimation of static accesibility J.Mol.Biol.1971:55, 379-400.

160. E.B.Saff and A.B.J.Kuijlaars, The Mathematical Intelligencer. 1997, 19, 511.

161. Winn MD, Ballard CC, Cowtan KD, Dodson EJ, Emsley P, Evans PR, Keegan RM, Krissinel EB, Leslie AG, McCoy A, McNicholas SJ, Murshudov GN, Pannu NS, Potterton EA, Powell HR, Read RJ, Vagin A, Wilson KS. Overview of the CCP4 suite and current developments. Acta Crystallogr D Biol Crystallogr. 2011:67(4):235-42.

162. Domingues $R$, Font $P$, Sobrinho $L$, Bugalho $M J$ A novel variant in Serpina7 gene in a Family with thyroxine-binding globulin deficiency. Endocrine. 2009; 36:83-86.

163. Fingerhut A, Reutrakul S, Knuedeler SD, Moeller LC, Greenlee C, Refetoff S, Janssen OE. Partial deficiency of thyroxinebinding globulinAllentown is due to a mutation in the signal peptide. J Clin Endocrinol Meta. 2004;89:2477-2483.

164. Sharman, GB. Late DNA replication in the paternally derived $\mathrm{X}$ chromossome of female kangaroos. Nature.1971;230(5291):231-2.

165. Nascimento DM, Otto PA, DE Brouwer AP, Vianna - Morgante, AM. UBE2A, which encodes a ubiquitin-conjugating enzyme, is mutated in a novel X-linked mental retardation syndrome. Am. J. Hum. Genet. 2006;79( 3):549-55 
166. Brown CJ, Robinson WP 2000. The causes and consequences of random and no-random x chromosome inactivation in humans. Clin Genet 58:353-363.

167. Shevchenko Al, Zakharova IS. The Evolutionary Pathway of $X$ Chromosome Inactivation in Mammals. Acta Naturae.2013;5(2):40-53.

168. Mannavola D, Vannucchi G, Fugazzola L, Cirello V, Campi I, Radetti G, Persani L, Refetoff S, Beck-Peccoz P. TBG deficiency: description of two novel mutations associated with complete TBG deficiency and review literature. J Mol Med. 2006; 84:864-871.

169. Carvalho $G A$, Weiss $R E$, Refetoff $S$ Complete thyroxinebinding globulin (TBG) deficiency produced by a mutation in acceptor splice site causing frameshift and early termination of translation (TBG-Kantakee). J Clin Endocrinol Metab. 1998;83:3604-3608.

170. Moeller LC, Appiagyei-Dankah Y, Köhler B, Biebermann H, Janssen OE, Fuhrer D. Two Novel Mutations in the Serpina7 Gene Are Associated with Complete Deficiency of Thyroxine-Binding Globulin. Eur Thyroid J.2015;4 (suppl 1):108-112.

171. Domingues R, Bugalho MJ, Garrao A, Boavida JM, Sobrinho L Two novel variants in the thyroxine-binding globulin (TBG) gene behind the diagnosis of TBG deficiency. Eur J Endocrinol 2002;146:485-490.

172. Su Ching-Chien, Wu YC, Chiu CY, Won JG, Jap TS Two novel mutations in the gene encoding thyroxine-binding globulin (TBG) as a cause of complete TBG deficiency in Taiwan. ClinEndocrinol. 2003;58:409-414.

173. Bertenshaw R, Sarne D, Tornari J, Weinberg M, Refetoff S Sequencing of the variant thyroxine-binding globulin (TBG) - San Diego reveals two nucleotide substitutions. Biochim Biophys Acta. 1992;1139:307-310.

174. Sklate RT, Olcese MC, Maccallini GC, Sarmiento RG, Targovnik HM, Rivolta CM. Novel mutation p.A64D in the Serpina7 as a cause of partial thyroxine-binding globulin deficiency associated with increases affinity in 
transthyretin by a known p.A109T mutation in the TTR gene. Horm Metab Res. 2014;46(2):100-8.

175. Mori Y, Seino S, Takeda K, Flink IL, Murata Y, Bell GI, Refetoff S A mutation causing reduced biological activity and stability of thyroxine-binding globulin probably as a result of abnormal glycosylation of the molecule. Mol Endocrinol 1989;3:575-579.

176. Janssen OE, Takeda K, Refetoff S. Sequence of the variant thyroxinebinding globulin (TBG) in a Montreal family with partial TBG deficiency. Hum Genet .1991;87:119-122.

177. Moeller LC, Edidin DV, Jaeger A, Mann K, Refetoff S. A novel mutation leading to familial partial thyroxine-binding globulin deficiency (TBG Glencoe). 14th International Thyroid Congress; September 11-16, 2010; Paris, France.

178. Bertenshaw R, Takeda K, Refetoff S. Sequencing of the variant thyroxine-binding globulin (TBG)-Quebec reveals two nucleotides substitutions. Am J Hum Genet 1991;48:741-744.

179. Shirotani T, Kishikawa H, Wake N, Miyamura N, Hashimoto $Y$, Motoyoshi S, Yamaguchi K, Shichiri M. Thyroxine-binding globulin variant (TBGKumamoto): identification of a point mutation and genotype analysis of its family. Endocrinol Jpn 1992;39:577-584.

180. Miura Y, Mori Y, Kambe F, Tani Y, Oiso Y, Seo H. Impaired intracellular transport contributes to partial thyroxinebinding globulin deficiency in a Japanese family. J Clin Endocrinol Metab. 1994;79:740-744.

181. Yorifuji T, Muroi J, Uematsu A, Momoi T, Furusho K. Identification of a novel variant of the thyroxine-binding globulin (TBG) in a Japanese patient with TBG deficiency (abstract). Horm Res 1998; 50 (suppl 3):68.

182. Ueta Y, MitaniY, Yioshida A, Taniguchi S, Mori A, Hattori K, Hisatome I, Manabe I, Takeda K, Sato R, Ahmmed GU, Tsuboi M, Ohtahara A, Hiroe K, Tanaka $Y$, Shigemasa $C$. A novel mutation causing complete deficiency of thyroxine binding globulin. Clin Endocrinol. 1997;47:1-5. 
183. Miura $Y$, Hershkovitz E, Inagaki A, Parvari R, Oiso Y, Phillip M. A novel mutation causing complete thyroxine-binding globulin deficiency (TBG-CDNegev) among the Bedouins in southern Israel. J ClinEndocrinol Metab. 2000; 85:3687-3689.

184. Lacka K, Nizankowska T, Ogrodowicz A, Lacki JK A novel mutation (del1711G) in the TBG gene as a cause of complete TBG deficiency. Thyroid.2007;17:1143-1146.

185. Reutrakul S, Janssen OE, Refetoff S 2001 Three novel mutations causing complete T4-binding globulin deficiency. J Clin Endocrinol Metab 86:5039-5044.

186. Yamamori I, Mori $\mathrm{Y}$, Seo H, Hirooka $\mathrm{Y}$, Imamura S, Miura $\mathrm{Y}$, Matsui N, Oiso $\mathrm{Y}$. Nucleotide deletion resulting in a frameshift as a possible cause of complete thyroxine-binding globulin deficiency in six Japanese families. J Clin Endocrinol Metab 1991;73:262-267.

187. Yamamori I, Mori Y, Miura Y, Tani Y, Imamura S, Oiso Y, Seo H. Gene screening of 23 Japanese families with complete thyroxine-binding globulin deficiency: Identification of a nucleotide deletion at codon 352 as a common cause. Endocr J 1993; 40:563-569

188. Waltz MR, Pullman TN, Takeda K, Sobieszczyk P, Refetoff S. Molecular basis for the properties of the thyroxine-binding globulin-slow variant in American blacks. J Endocrinol Invest .1990;13:343-349.

189. Daiger SP, Rummel DP, Wang L, Cavalli-Sforza LL. Detection of genetic variation with radioactive ligands. IV. X-linked, polymorphic genetic variation of thyroxin-binding globulin (TBG). Am J Hum Genet 1981; 33:640-648.

190. Takamatsu J, Ando M, Weinberg M, Refetoff S. Isoelectric focusing variant thyroxine-binding globulin (TBG-S) in American Blacks: Increased heat lability and reduced concentration in serum. J Clin Endocrinol Metab. 1986; 63:80-87. 
191. Janssen OE, Chen B, Buttner C, Refetoff S, Scriba PC Molecular and structural characterization of the heat-resistant thyroxine-binding globulinChicago. J BiolChem. 1995;270:28234-28238.

192. Takamatsu J, Refetoff S. Inherited heat stable variant thyroxine-binding globulin (TBG-Chicago). J Clin Endocrinol Metab 1986; 63:1140-1144.

193. Cooper DN, Yousoufian H The CpG dinucleotide and human genetic disease. Hum Genet. 1988; 78:151-155.

194. Den Dunnen JT, Antonarakis SE Mutation nomenclature extensions and suggestions to describe complex mutations: a discussion. Hum Mutat. 2000; $15: 7-12$

195. Moeller LC, Vinzelberg P, Jaeger A, Appiagyei-Dankah Y, Fingerhut A, Mann K, Janssen OE. Two novel mutations leading to partial and complete thyroxine-binding globulin deficiency. 51. Symposium of the German Society for Endocrinology, March 7e11 2007, Salzburg, Austria.

196. Graham A, Kalsheker NA, Newton CR, Bamforth FJ, Powell SJ, Markham AF Molecular characterisation of three alpha-1-antitrypsin deficiency variants: proteinase inhibitor (Pi) nullcardiff (Asp256----Val); PiMmalton (Phe51---deletion) and Pil (Arg39----Cys). Hum Genet. 1989:Dec;84(1):55-8. 


\section{APÊNDICE A - TERMO DE CONSENTIMENTO LIVRE E ESCLARECIDO}

\section{TERMO DE CONSENTIMENTO LIVRE ESCLARECIDO}

Você está sendo convidado(a) a participar, como voluntário(a), da pesquisa clínica intitulada "Mecanismos moleculares envolvidos na deficiência congênita de TBG (globulina carreadora de tiroxina)" realizada no Hospital Universitário de Brasília-HUB, Setor de Endocrinologia e Metabologia.

Sua participação neste estudo é voluntária. Trata-se de uma pesquisa a respeito da doença de que você é portador (ou alguns de seus parentes), isto é, deficiência da globulina carreadora de tiroxina (TBG). Esta globulina é uma proteína presente no sangue que tem a função de transportar o hormônio da tireoide no sangue até os órgãos e tecidos do corpo. A deficiência desta proteína causa uma alteração nas dosagens laboratoriais dos hormônios tireoideanos, que é semelhante ao hipotiroidismo, mesmo quando eles são produzidos normalmente. Portanto, detectar a deficiência de TBG é importante, pois evita o uso desnecessário de hormônio tireoideano nos portadores dessa alteração. Esta pesquisa servirá para verificar se existem causas genéticas para doenças que afetam a produção da TBG, bem como os seus mecanismos. É possível que estas doenças sejam causadas por problemas genéticos que podem ser herdados em pessoas da mesma família, e os médicos responsáveis por esta pesquisa estão tentando descobrir quais alterações podem causar deficiência de TBG. A sua participação nesta pesquisa é importante para os avanços dos conhecimentos da Medicina, que ocorrem por meio de estudos como este.

Será solicitado, após a leitura, que você assine o Termo de Consentimento Livre e Esclarecido (TCLE), em duas vias, ficando uma com você e outra com o pesquisador. Em seguida, será coletada uma amostra de sangue que ficará armazenada no Laboratório de Farmacologia Molecular da UnB, para realização do exame molecular. Esses procedimentos serão realizados durante sua consulta de rotina, onde também serão verificados seus dados e de sua história médica. Você poderá se recusar a responder qualquer pergunta que the cause constrangimento. $\mathrm{O}$ seu acompanhamento clínico continuará seguindo normalmente.

A amostra de sangue (de 10 a $20 \mathrm{~mL}$ ) será coletada de uma veia do antebraço, utilizando uma agulha e seringa (descartáveis). As complicações que podem ocorrer devido a este procedimento são: leve dor, inchaço (inflamação), infecção ou uma marca "preto-azulada" no local da picada (hematoma).

A partir da coleta do sangue, serão cultivadas as células brancas do seu sangue para obter DNA (seu código ou identidade genética), para que nele sejam estudados alguns genes que possam estar alterados e causar doenças.

Os resultados desta pesquisa poderão esclarecer as causas genéticas e mecanismos envolvidos na deficiência de TBG. Isso poderá contribuir para a sua saúde diretamente e para a de seus familiares, pois, caso seja encontrada uma mutação, isso poderá determinar a necessidade ou não de tratamento da sua condição. 
Você poderá ter acesso a todas as informações e esclarecimentos que desejar a qualquer momento, antes ou durante a pesquisa. A decisão de não participar, ou de se retirar do estudo depois do mesmo já ter iniciado, não ocasionará nenhum problema no seu tratamento no HUB, bastando para isto comunicar o seu desejo ao pesquisador responsável.

Nenhum tipo de pagamento será feito pela sua participação como voluntário(a) nessa pesquisa, e todas as despesas necessárias para a realização da pesquisa não serão de sua responsabilidade.

Todas as informações acerca dos dados obtidos, inclusive biológico (amostra de sangue), serão utilizadas exclusivamente para fins do estudo. Por serem confidenciais, estarão restritas ao prontuário médico da instituição.

Os resultados do estudo poderão ser publicados em revistas médicas nacionais e ou internacionais, apresentados em congressos ou eventos científicos ou às autoridades sanitárias, sem que seu nome seja mencionado em parte alguma.

Assinando este consentimento você estará autorizando o acesso ao seu prontuário médico sem, no entanto, renunciar aos seus direitos.

Se durante o estudo houver necessidade de esclarecer alguma dúvida entre em contato com a Dra. Adriana Lofrano Alves Porto pelo telefone 31071748 ou pelo email adlofrano@unb.br.

Outras informações a respeito dos procedimentos ou questões éticas, você poderá obter com o Comitê de Ética em Pesquisa com Seres Humanos da Faculdade de Ciências da Saúde da Universidade de Brasília pelo telefone 3107-1947 ou no local.

\section{DECLARAÇÃO DO PACIENTE}

$\mathrm{Eu}$, voluntariamente, concordo em participar do Estudo acima, a ser realizado no HUB/UNB. Declaro ter lido e compreendido este TCLE, fui informado de todos os dados, pude fazer perguntas e recebi respostas que me satisfizeram. Se eu não participar ou se eu decidir suspender minha participação neste estudo, não serei penalizado e não renunciarei a quaisquer direitos legais. Eu recebi uma cópia deste TCLE.

Assinatura do paciente:

Assinatura do responsável legal:

Data: / / 
Nome da pessoa que conduziu a discussão do consentimento:

Assinatura do Investigador:

Prof. Dra. Adriana Lofrano Alves Porto

Professora Adjunta do Curso de Ciências Farmacêuticas - UnB

Endocrinologista - Hospital Universitário de Brasília

Contato: ambulatório de Endocrinologia - HUB (quintas-feiras à tarde) - 3448-

5255

Laboratório de Farmacologia Molecular - 3107-1748

Email: adlofrano@unb.br 


\section{APÊNDICE B - ELETROFORESE EM GEL DE AGAROSE}

Resultado da eletroforese em gel de agarose $1,5 \mathrm{X}$ da amplificação da região de repetição CAG do gene $A R$.

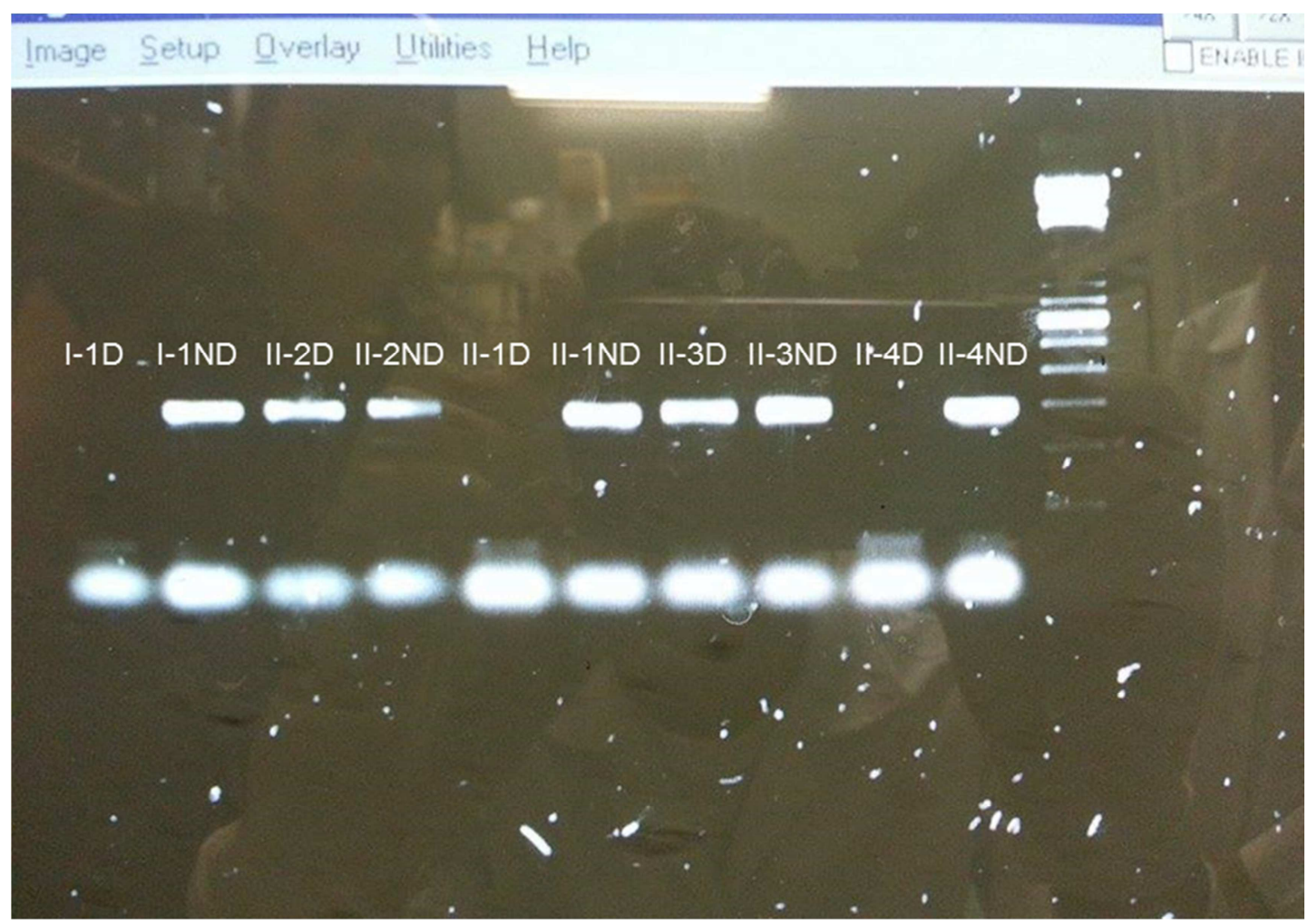

Legenda:

D: amostras submetidas a digestão com enzima Hhal

ND: amostras sem enzima.

I-1: amostra do pai não afetado

II-2: amostra do caso índice

II-1: amostra do irmão afetado

II-3: amostra da irmã gêmea não afetada

II-4: amostra do irmão afetado 


\section{APÊNDICE C - IMAGENS DOS RESULTADOS DOS SEQUENCIAMENTOS}

Resultado do sequenciamente dos indivíduos: I-1 (Pai), II-1 (Irmão afetado), II-3 (irmã gêmea não afetada), II-4 (Irmão afetado) e II-2 (caso índice).

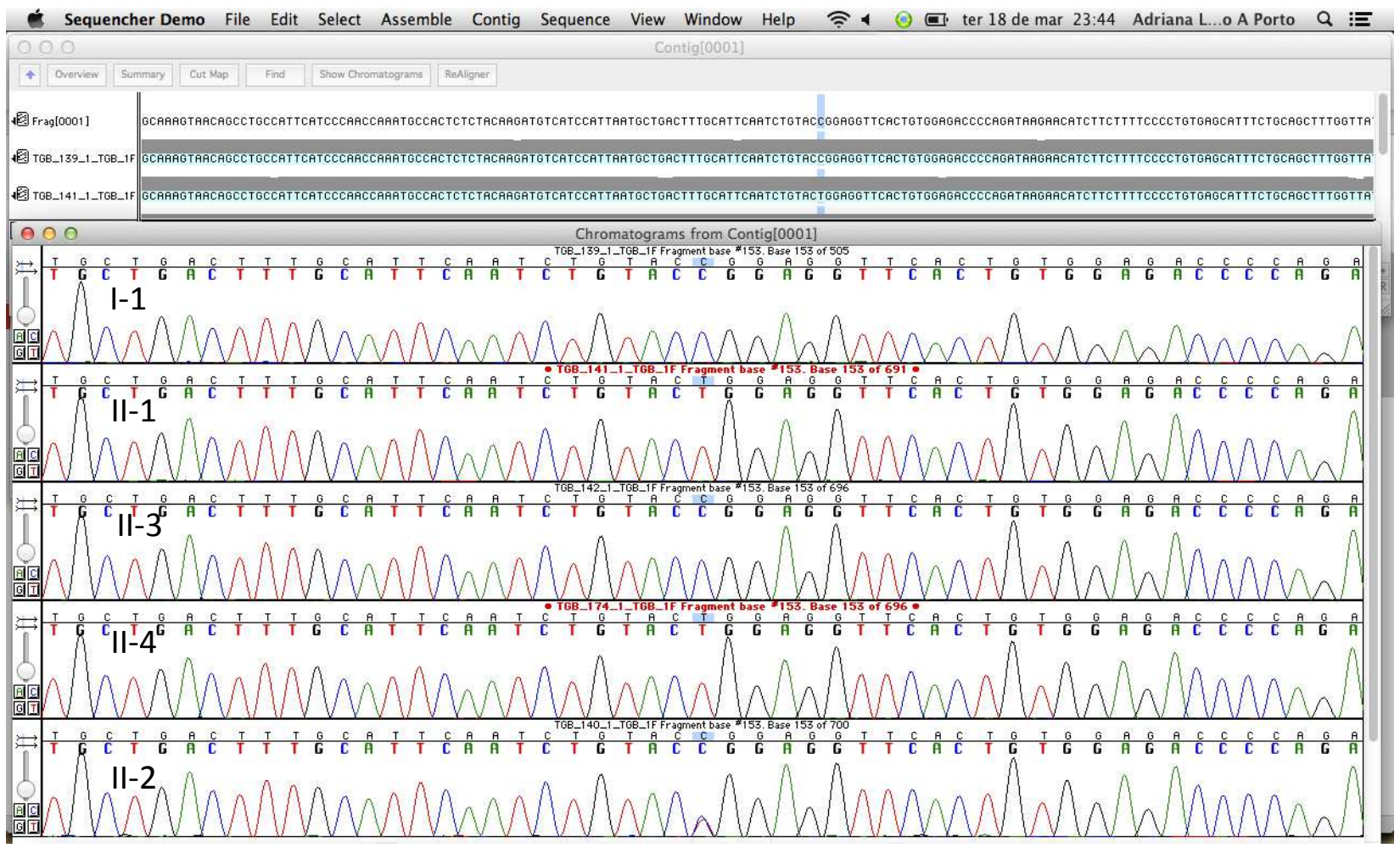

\section{APÊNDICE D - RESULTADOS DOS EXAMES LABORATORIAIS DAS TIAS MATERNA DO CASO ÍNDICE}

\begin{tabular}{lcccc}
\hline & Tia Materna 1 & Tia Materna 2 & Tia Materna 3 & $\begin{array}{c}\text { Valor de } \\
\text { Referência }\end{array}$ \\
\hline $\mathrm{TT}_{4}$ & 1,13 & 11,9 & 9,2 & $3,2-12,6 \mu \mathrm{gg} / \mathrm{dL}$ \\
$\mathrm{TT}_{3}$ & 66 & 122 & 115 & $60-181 \mathrm{ng} / \mathrm{dL}$ \\
Anti TPO/Tg & + & + & - & - \\
TBG & 10,8 & 24 & 19,5 & $13,6-27,2 \mathrm{mg} / \mathrm{L}$
\end{tabular}




\section{APÊNDICE E - RESULTADOS DA ANÁLISE IN SILICO}

Análise in silico da mutação encontrada usando a sequência requerida para software público polyphen-2 (http://genetics.bwh.harvard.edu/pph2)

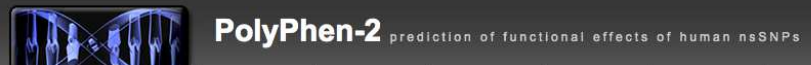

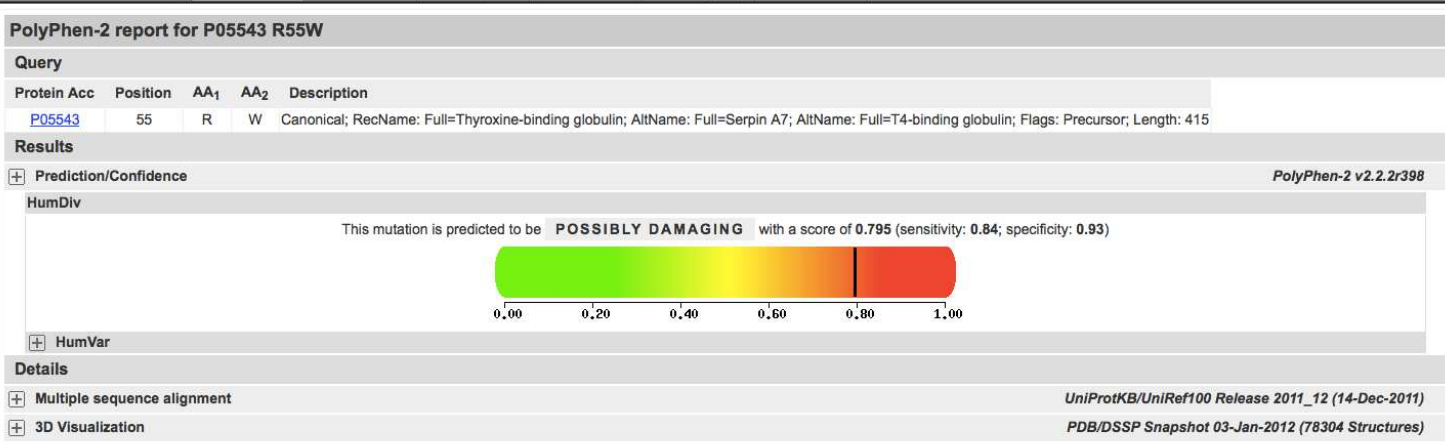

\section{APÊNDICE F - TESTE DE ESTÍMULO COM TRH DO CASO ÍNDICE}

\begin{tabular}{lccccccccc}
\hline $\begin{array}{l}\text { Caso } \\
\text { índice }\end{array}$ & Basal & 15min & 30min & $45 \mathrm{~min}$ & $60 \mathrm{~min}$ & $90 \mathrm{~min}$ & $120 \mathrm{~min}$ & $\begin{array}{l}\text { Valor } \\
\text { referência } \\
\text { basal }\end{array}$ & $\begin{array}{l}\text { Valor } \\
\text { referência } \\
\text { pós-TRH }\end{array}$ \\
\hline $\begin{array}{l}\text { Curva } \\
\text { prolactina } \\
- \text { pós }\end{array}$ & 7,26 & 62,71 & 62,83 & 41,82 & 36,56 & 27,43 & 22,08 & $\begin{array}{l}0,33-27,33 \\
\mathrm{ng} / \mathrm{mL}\end{array}$ & $3 \mathrm{X}$ basal \\
$\begin{array}{l}\text { estímulo } \\
\text { TRH }\end{array}$ & & & & & & & & & \\
$\begin{array}{l}\text { Curva TSH- } \\
\text { pós } \\
\text { estímulo }\end{array}$ & 3,44 & 16,81 & 21,89 & 21,03 & 16,91 & 13,86 & 10,91 & $0,35 \mathrm{a}$ & $<25$ \\
TRH & & & & & & & & $5,50 \mathrm{uUl} / \mathrm{mL}$ & $\mathrm{uUl} / \mathrm{mL}$ \\
\hline
\end{tabular}


ANEXO 1 - PARECER CONSUBSTANCIADO DO CEP

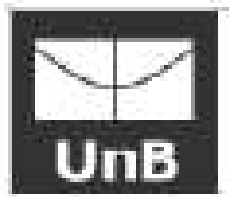

FACULDADE DE CIÊNCIAS DA

SAÚDE DA UNIVERSIDADE DE BRASILIA - CEP/FS-UNB

\section{PARECER CONSUBSTANCIADO DO CEP}

DADOS DO PROJETO DE PEAQUISA

Thulo da Pegquica: MECANIBMOS MOLECULAREB ENVOLVIDOS NA DEFICIENCIA CONGENITA DE TBG (GLOBULINA CARREADORA DE TIROXINA)

Pocquleador: Adriana Lotane Aves Forto

Aroa Tematioa: Genetica Humana:

(Trata-se de pesquisa envolvendo Genetica Humana que nfo necessta de anallse titica por parte da CONEP;)

Vertso: 1

CAAE: 43417815.6 .0000 .0030

Inetitulǫso Proponente: Facuidade de Ciencias da saude da Univerzidade de Eraslils

Patrooinador Prinolpal: Financlamento Preprio.

DADOS DO PARECER

Nemore do Pareoer: $1.215,947$

Aprecontap̧so do Projeto:

O esoudo refere-se a um "(reiato) de uma familla com dlagnostico de defelencia parcial de TeG," Para tanto, realizar-ge-t "analige molecular do gene SERPINA 7 que codiflea a TEG." A globulina carreadora de tiroxina (TBG) e a principal proteina transportadora dos hormonios treoldacos em humanoa. Desordens heredtarias que comprometem a eatrutura e funçlo da proteina resultam em deficlencis parcial e completa de TBG (TBG-FD e TBG-CD, reapectivamente), $Q$ objetivo do prezente trabalho serd realzar o eatudo moiecular do gene que codifica a TBG (BERPINA7) em uma familia, na qual uma mumer (probanda) apresentou-se com TBG-PD, diagnosticada clinicamente. Q DNA gendmico sers extraida da probanda, pals e Irmblos, apos assinatura do TCLE. Reaç\$o de polimerizaçbo em cadela (FCR) sera utilizads para ampitncaçbo do gere sERPINA7 e os produtos serdo submetidos a sequenclamento automatco. O padrio de Inatvaçsto do cromossomo $x$ sera avaliado ns probands por meio da analise do padrío de metiaçlo do gere do receptor androgenico. A raridade deata altuaçso clinica e a busca de meihor entendimento das reiajbes de estrutura e funçbo da oroceina justincam o estudo de caracterizap̧lo genetica e moiecular da familla afetada."

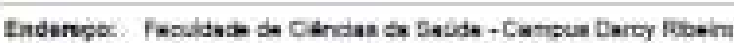

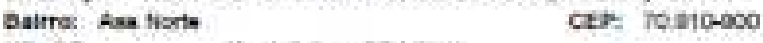

UF: De Municiples antacia

Taletoce: : Fis gidit-vat

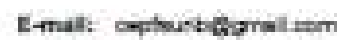




FACULDADE DE CIÊNCIAS DA
SAULDE DA UNIVERSIDADE DE
BnEASILIA - CEPIFS-UNB

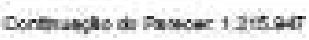

Objetlvo da Pocquica:

verificar a ocorrencia de mutaçbes no gene aERPINA7 em uma mulher (caso indice) e seus dola imndos dlagnoaticadoa com deficlencla parcial congenla da TBG." Invest gar posatvela mecaniamos de

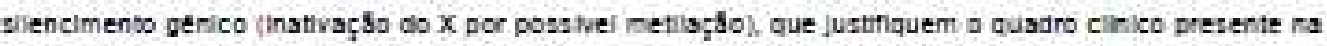
mulher (caso indice):

\section{Avallopso doe Rlcooc o Benotloloc:}

Ha um desconforto minimo em decorrencla da coleta de amostra de asogue fcerca de 1 dumL; o squivalente a duas coiheres de cha) que sfo: leve dor no local da punçSo, inchap̧o, infiamap̧lo ou uma mancha "pretoazulada" no local da picada (hematoma revershelj. "Fara minimizar esse risco, a coleta serb realzada por um profasionai da area de sade capacitado e esse procedimento sera realzado durante a sua conauta ambulatorial de rotina ou no momento da coleta de outros exames que fazem parte do seu acompanhamento cilinico. NSo se visiumbram outros danos imediatos ou posteriores, no plano indliduas ou coletivo. N5o ocorrert adminiatraçlo de medicamentoa nem serbo realizados outros procedimentos diagnesticos, atem daqueies que constem nos prontuarios do particloantes do estudo, como parte da rotina cinica para a sua condiç5so." Ainda como beneficios para os participantes, "os resultados desta pesquisa poderSo esciarecer se eriste causa genetca para a sua doença. Caso seja encontrada uma mutaçdo gentica, isso podera ser uttl para o dagnostico de outroa merobros da sua famila, ou ainda, para 0 esclarecimento da doença de outras pezsoas que tenham o meamo probiema.

\section{Comentarloc o Conclderap̧oc cobre a Pecqulea:}

Trata-se de um eetudo descritivo, cinico e genetico, de uma fanllia em que fol diagnosticada cinicamente defelencia parcial de globulina lijadora de troxina (TeG). Bera felta a descriço cilinica dos individuos afetados e seus tamilares que concordarem em particlpar do estudo, com base nos dados presentes ent seus prontuartos de asjuimento clinico no ambulatorio de endocrinologia. Alem dlsa, sera realzada analse molecular do gene que codiflca a TBG (BERPINA 7), a oartir do DNA extraido dos participantes." A leitura de prontatrio permitira obter dados elinicos como: "anamnese, erame tisico, dosagens hormonala e bloquimica sanguinea", este procedimento faz "parte da rotina clinica de inveetgap̧a e acompanhamento de 5 reopatas. Ansies moiecular 1. Extraç4o de DNA gendmico de ieucocitos do zangue perfferico: O DNA genomico sert extroida a partr de ieucocoos obtidos de amostra de 10 a 20 mi de sangue tota utilizando 0 metodo de 3aiting-out ou kite osponheis (Cheiex 100 ou Giagen). 2. Desenho dos primera: Realizados a partir das sequenclas refertnda dlsponlveis no pubmed, com a uso de

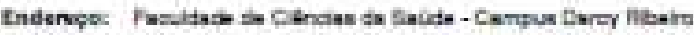

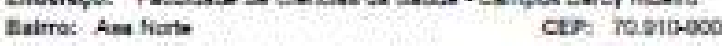

UF: DE Municiples: Bhasele

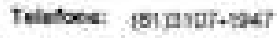

Ethat: - whutbegrat. vom 


FACULDADE DE CIÊNCIAS DA
SAULE DA UNIVERSIDADE DE
BRE

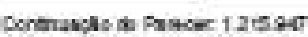

softwares especificos (PR.MER3). 3, ReaçSo de Poilmerizaç5̆o em cadela (PCR): O DNA gensmico sers

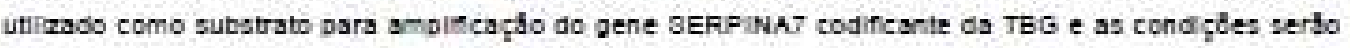
definidas contorme eapecindade dos primers. 4. Funficaçlo dos produtos de PCR e sequenclamento sutomstico: Os produtoa da ampleficaçbo ser\$o purificados por meio enzimatica utlizado o sistems EXoBAP $=$ os produtos desta reş̧bo serbo submetidos a sequenclamento sutomstico. As ielturas das sequenclas zerfo realizadas utlizando sothwares especificos (sequencher) 5 . Avaliaçso do atatus de instivaçlo do cromossomo $\mathrm{X}$ : Caso se conflime a mutaçbo no cromossomo $\mathrm{X}$ ds paciente do sexo feninino, sera avaliado o podrbo de metilaçbo (alienciamento) de genes conhecidos deste cromossomo: O cronogramo da pesquias preve o inicio para novembro de 2015 e termino ero janeiro de 2015. Os recursos financeiros serbo provenientes do Laboratorio de Farmacologla Molecular Fo-Una, e somam sproximadamente quatro mil reals (Rs 4,000,00) A pesqulesdors compde a equipe deste Laboratorio: Trata-se de um projeto de pesquisa da Prefa. Adrians.

Conelderapoec cobre oc Termoc de aprecentagso obrigatorla:

A pesquisadora apresentou or seguintes documentos:

(1) Molha de rosto thg asainada paf, 29/07/2015,a pesquisadora informa que "Trata de pesquisa envoivendo Genetica Humans que n\$o necesalta ansise etica por parte do CONEP. A Fol ha de Rosto fol devidamente preenchids, com assinatura e carimbo da pesquisadora professora Adriana Lofrano Aives Porto e da Diretora da Faculdade de clencias da eadde -FS-UnB profeseora Maris Fatima de sousa;

(2) "termo ciencla hub TaG asainado.jpg 29/07/2015"; o documento da instituiç\$o coparticlpante HUBIEBDERH tem a assinatura e carimbo do auperintendente do HUEIEBSERH, Dr. Hervaido Sampalo Carvaino do OR. Marcelo O. Rodrigues, Chefe do setor de Fesquisa e inovaçío Tecnologica do HUB?EBSERH:

(3) "lemo concordancla HUB TEG asainsdo Jpg. 29:07/2015"; eate documento ds Inatituifflo coparticipante HUGIEBBERH tem a asainatura e carimbo do superintendente do Hospital, Dr. Hervaldo Bampaio Canaho; do DR. Marcelo O. Rodrigues, Chefe do setor de Pesqulea e inovaçfo Tecnologica deate hospltal da Dra. Luclana A. Naves, Chetia responsavel pela Unidade Clinica/academica desta institulçbio coparticipante. Neate Temo de Conconasncis e deciarado que 0 estudo "envolve revisbo de prontuario e analse de DNA dos participantes (1 familia com 5 inalviduos com defclencia de TBG 7 , deciars ainda que 0 estudo terd duraçto de 3 meses e com previaso de iniclar em junhor20 15, :

(4) "cartaencaminhprojeto a CEF.F3_TGB.pdf, 07/09/2015", encaminhada pela pesquisadors:

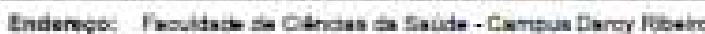

Eairro: Am Nart ? ceb Tosicaco

Ut: $\mathrm{DE}$ Muriejple; bitases

Talehose: isigasor-124t

E-mul: coburbohorstrom 


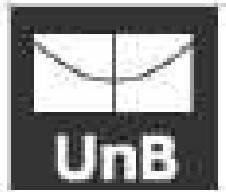

\section{FACULDADE DE CIÊNCIAS DA SAÚDE DA UNIVERSIDADE DE BRASILIA - CEP/FS-UNB}

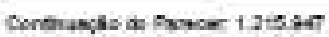

(E) TermoReapCompromPesq CEF_TGB.PDF, 07108R015"; devidamente apresentsdo pela pesquasdora;

(5) "Frojeto Detalhado / Brochura Investigador - Frojeto para CEP_proleto detainado como na pisterasH_TGB.docx. 0T/08/2055";

(7) "TCLE / Termos de Assentimento f Juatifativa de Austncia - TCLE TBG finai.docr, 07i0Bi2015", encontra-se em linguagem clara e objettua e acesslvei aos participantes da pesquiea. Contem as informaçbes e orientaçbes necessarias pars o entendimento da execuçto da pesquisa:

(8) "informaçdes Basicas do Projeto - PE_INFORMAÇOEB_BABICAB_DO_PROJETO_497683.pdf, $071082015 \%$

(9) "Adrana Lofrano Avea Porto_Cumiculo Lattes pdi, 120a/2015".

(10) "Cristiane deyce Gomes Lima_curiculo iattes pdr, 120s/2015".

111) “Curriculo Lattez_andreasamaciel_22.05.pd", 1203/2015"

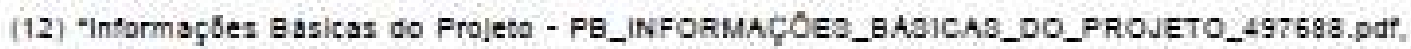
$12 / 08 / 2015^{*}$

Rooomendagoes:

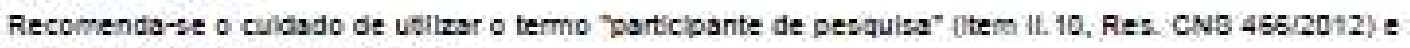
nSo "suleito de pesqualas", no TCLE.

Conoluo des ou Pondénolac o Llcta do inadequagoec:

O protocoio de pesquiza nao apresenta oblces eticos, eatando em conformidade com a Resoluçso CNB $466 / 2012$ e Complementares.

Conelderagese Finale a oritorio do CEP:

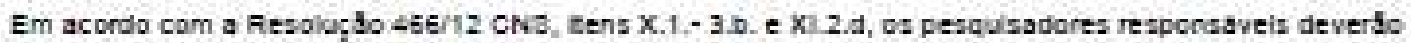
apresentar reiatorios parcial semestral = final do projeto de pesquisa, contados a parbr da data de aprovaçbo do protocolo de pesquias.

Ecte paroeer fol elaborado baceade noc dooumantoc abalko rolaolonadoc:

\begin{tabular}{|c|c|c|c|c|}
\hline Tipo Documento & Arqubvo & Footagem & Autor & Bbuaçdo \\
\hline Foina de Rosto & folha de rosto thg aseinads.pdf & $\begin{array}{c}29: 07 / 2015 \\
13: 33: 48 \\
\end{array}$ & & Aceto \\
\hline Qutros & termo clencla hub TBG assinado jpg & $29 / 07 / 2015$ & & AcelDo \\
\hline
\end{tabular}

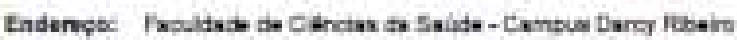

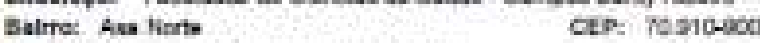

Ur: $\mathrm{By}$ Nurieiples shasicua

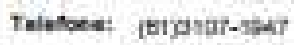

E-malt: cophenbogonalierm 


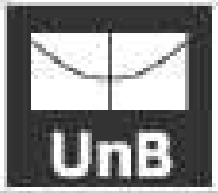

\section{FACULDADE DE CIÊNCIAS DA SAÚDE DA UNIVERSIDADE DE BRASILIA - CEPIFS-UNB}

Conthumelie do Pawcer-1.215sed

\begin{tabular}{|c|c|c|c|}
\hline Outros & termo ciencia hub TBG assinado.jpO & $19: 04: 10$ & Acebo \\
\hline Outros & $\begin{array}{l}\text { termo concondancis HUB TBG } \\
\text { assinado.jgo }\end{array}$ & $\begin{array}{c}29 / 07 / 2015 \\
19: 04: 57\end{array}$ & Aceito \\
\hline Outros & $\begin{array}{l}\text { cartaencaminhorojeto ao } \\
\text { CEP FB_.TGB.pd }\end{array}$ & $\begin{array}{l}07 / 08 / 2015 \\
16: 16: 19\end{array}$ & Acelo \\
\hline Outros & $\begin{array}{l}\text { TemoRespCompromfesa } \\
\text { CEP.TGB.PDF }\end{array}$ & $\begin{array}{c}07 / 08 / 2015 \\
16: 17: 02\end{array}$ & Acebo \\
\hline $\begin{array}{l}\text { Projeto Detahado I } \\
\text { Brochura } \\
\text { Investigadoc }\end{array}$ & $\begin{array}{l}\text { Projeto para CEP_proleto deta hado } \\
\text { como na pistarasl_tGa docx }\end{array}$ & $\begin{array}{c}07 / 08 / 2015 \\
16: 40: 58\end{array}$ & $A c=00$ \\
\hline $\begin{array}{l}\text { TCLE I Termos de } \\
\text { Aasentimento I } \\
\text { dustincasva de } \\
\text { Ausencia }\end{array}$ & TCLE TEG Pnal.doCX & $\begin{array}{c}07 / 082015 \\
16: 41 ; 18\end{array}$ & Acebo \\
\hline $\begin{array}{l}\text { Informaçbes Esaicas } \\
\text { do Proleto }\end{array}$ & $\begin{array}{l}\text { PB_NNOORMACQCEB_BABICAB_DO_P } \\
\text { ROJETO_497GBB.pof }\end{array}$ & $\begin{array}{c}07 / 03 / 2015 \\
16: 42: 55\end{array}$ & Acelos \\
\hline Outros & $\begin{array}{l}\text { Adriana Lotrano Aves Porto_Curriculo } \\
\text { Lattes pet }\end{array}$ & $\begin{array}{c}12: 03: 2015 \\
16: 05: 01\end{array}$ & Acetoo \\
\hline Outros & $\begin{array}{l}\text { Cristiane Jeycs Gomes Lima_curriculo } \\
\text { iattes.pof }\end{array}$ & $\begin{array}{c}1208 / 2015 \\
16: 05: 54\end{array}$ & Aceito \\
\hline Outros & $\begin{array}{l}\text { Curricuio } \\
\text { Lattea_andreasamaclel_2205.pdf }\end{array}$ & $\begin{array}{c}12: 08 / 2015 \\
16: 06: 49\end{array}$ & Acello \\
\hline $\begin{array}{l}\text { Informaçdes Easicas } \\
\text { do Projeto }\end{array}$ & $\begin{array}{l}\text { PB_INFORMACQOEO_BABICAB_DO_F } \\
\text { ROJETO_497SBB.pof }\end{array}$ & $\begin{array}{l}12 / 08 / 2015 \\
16: 07: 58\end{array}$ & Acebo \\
\hline
\end{tabular}

Situagso do Pareoer:

Aprovado

Neoecelta Apreolagso da CONEP:

Noso

BRABILIA, 05 de setembro de 2015

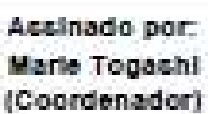

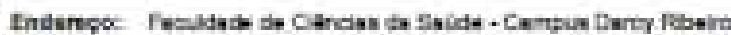

Eiairro: Aas Norto

cep: rovib-000

ur: DE

Muriciple: ahaBzu

Teletoce: |tiptpit-iok?

E-mat: ouphunbefornelexr 